
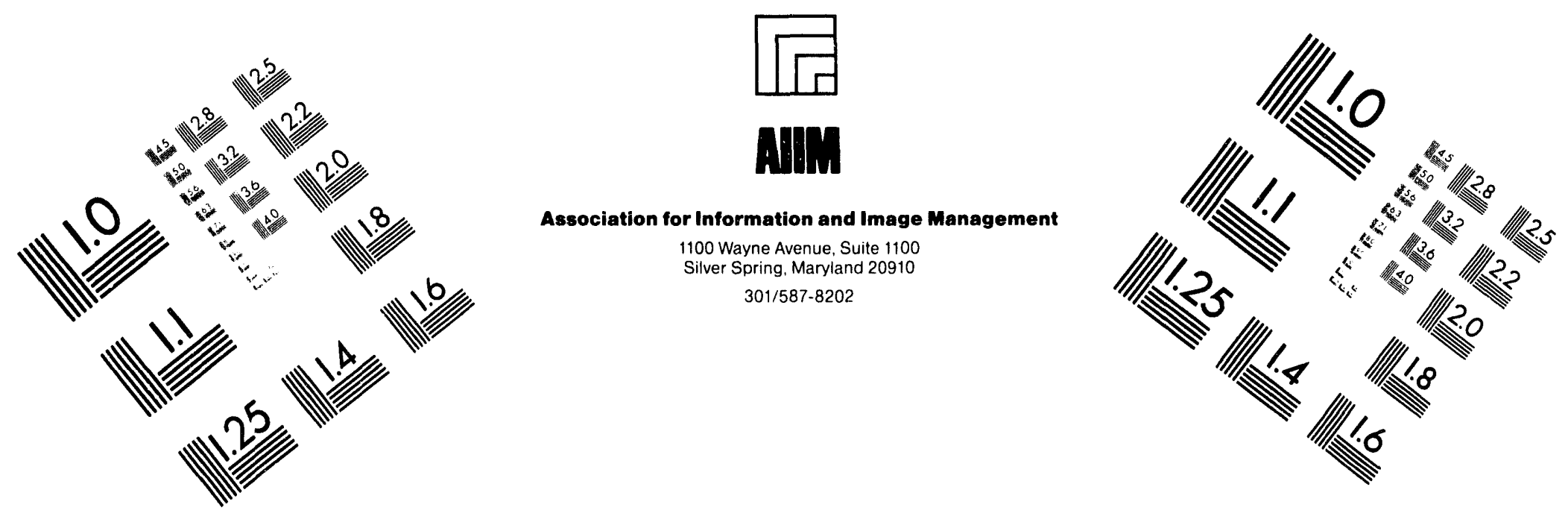

\title{
Centimeter
}

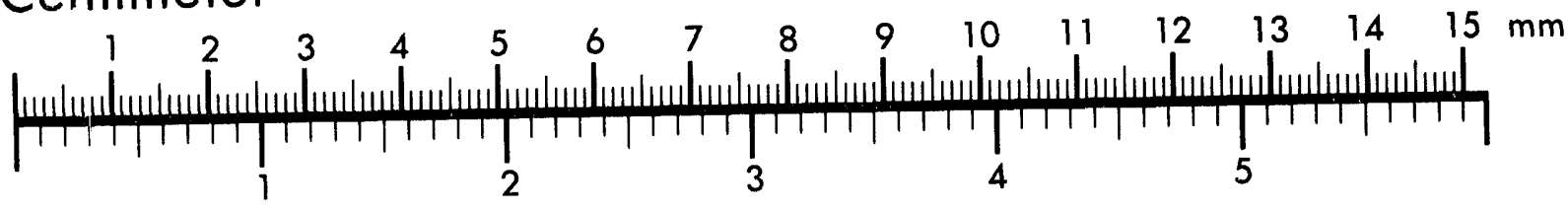
Inches
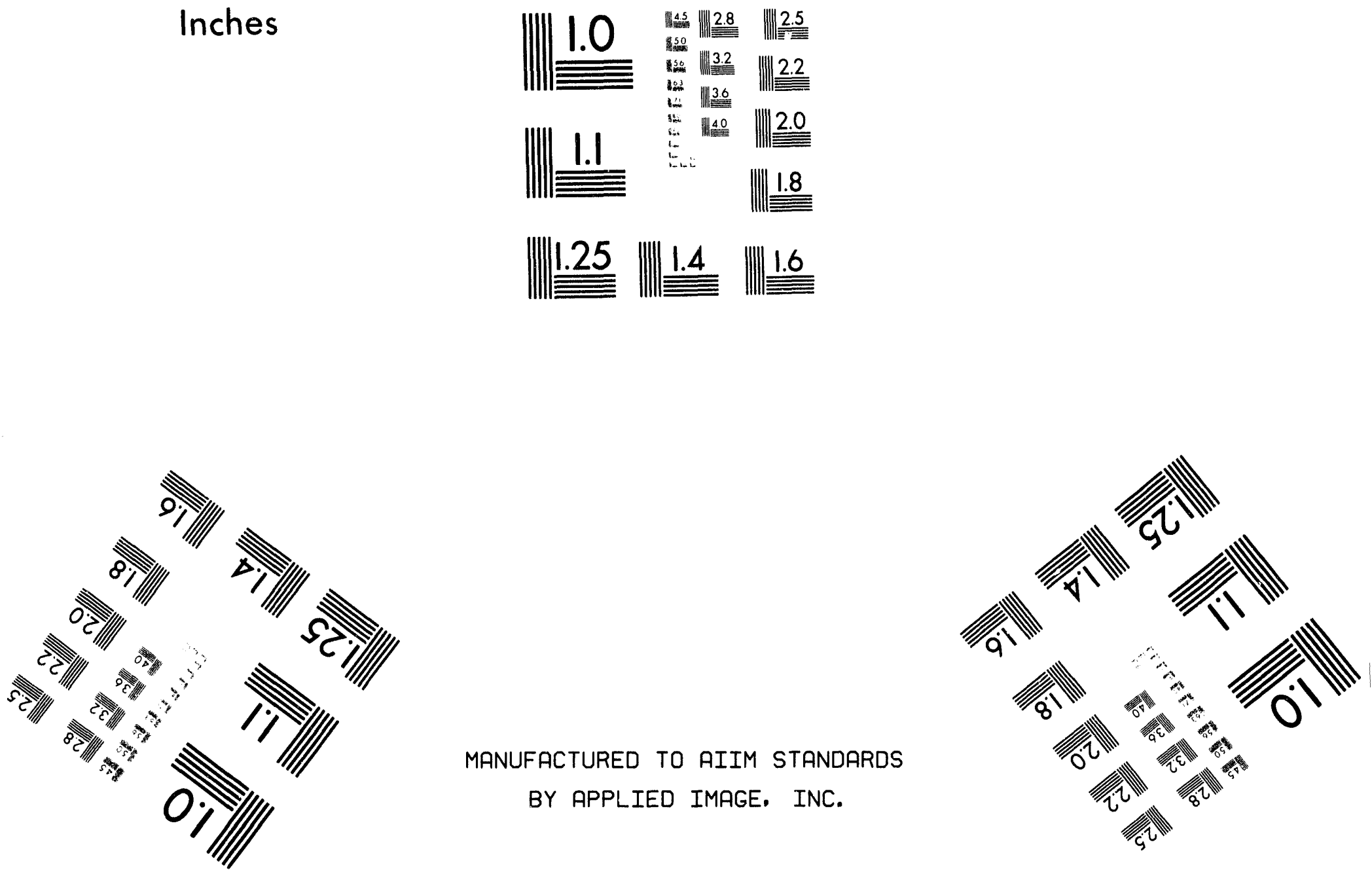

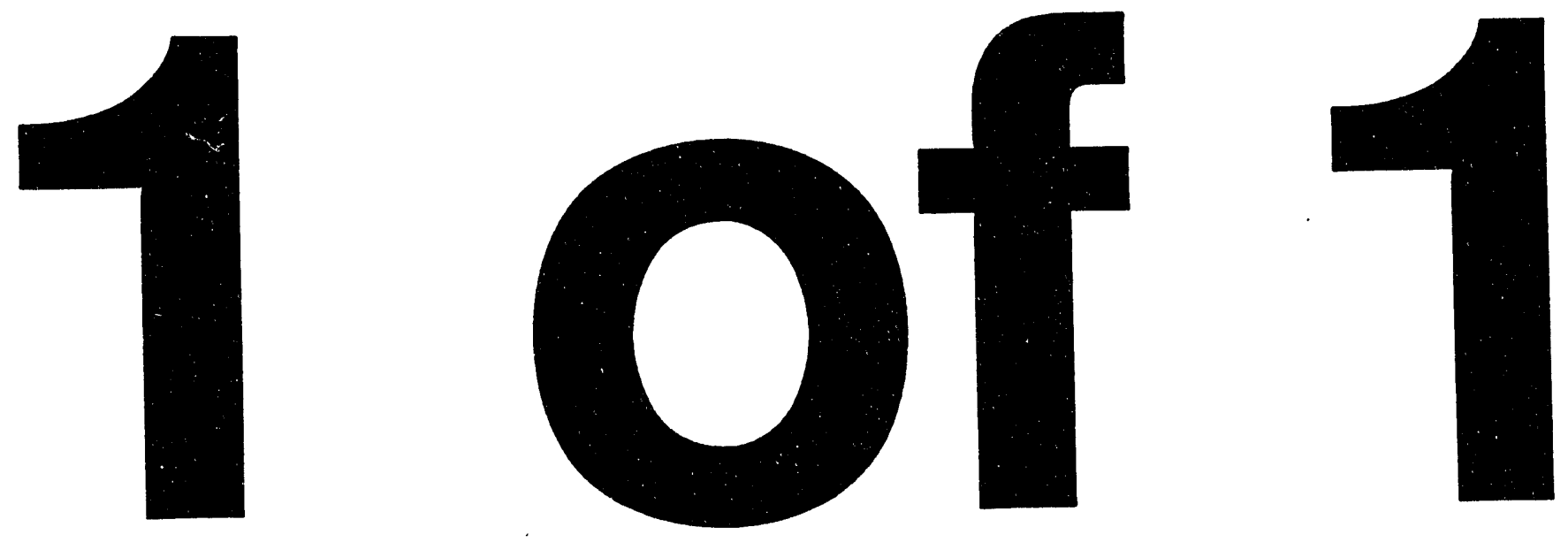


\section{Pore-Water Extraction from Unsaturated Tuff by Triaxial and One-Dimensional Compression Methods, Nevada Test Site, Nevada}

by TIMOTHY E. MOWER, presently affiliated with PRC Environmental Management, Inc., Denver, Colo.; JERRY D. HIGGINS, presently affiliated with Colorado School of Mines, Golden, Colo.; IN C. YANG; and CHARLES A. PETERS

U.S. GEOLOGICAL SURVEY

Water-Resources Investigations Report 93-4144

Prepared in cooperation with the

NEVADA OPERATIONS OFFICE,

U.S. DEPARTMENT OF ENERGY

(Interagency Agreement DE-Al08-92NV10874)

Denver, Colorado

1994

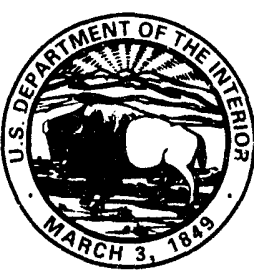




\title{
U.S. DEPARTMENT OF THE INTERIOR BRUCE BABBITT, Secretary
}

\author{
U.S. GEOLOGICAL SURVEY
}

Gordon P. Eaton, Director

The use of trade, product, industry, or firm names is for descriptive purposes only and does not imply endorsement by the U.S. Government.

For additional information write to:

Chief, Hydrologic Investigations Program Yucca Mountain Project Branch

U.S. Geological Survey

Box 25046, MS 421

Denver Federal Center

Denver, CO 80225
Copies of this report can be purchased from:

U.S. Geological Survey

Earth Science Information Center

Open-File Reports Section

Box 25286, MS 517

Denver Federal Center

Denver, CO 80225 


\section{CONTENTS}

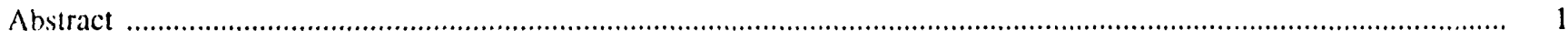

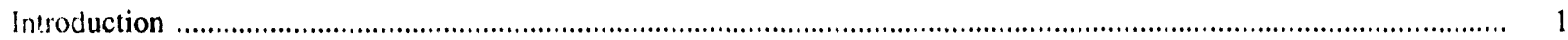

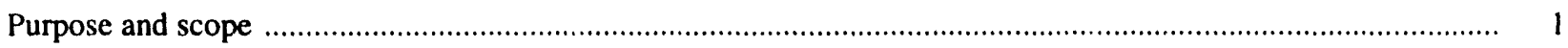

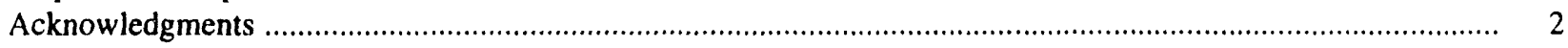

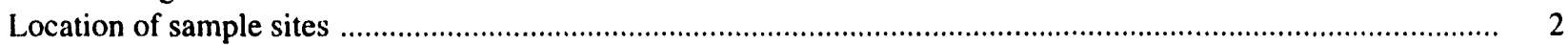

General geologic relations at the Nevada Test Site ……............................................................................. 2

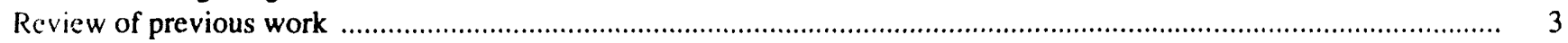

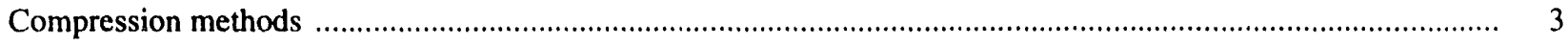

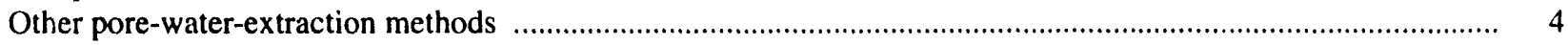

Compression methods for pore-water extraction ........................................................................................ 5

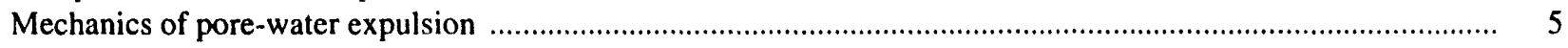

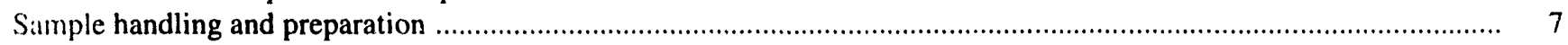

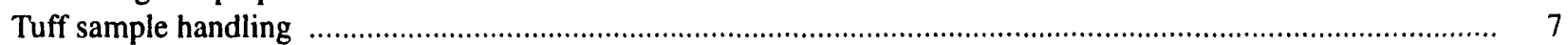

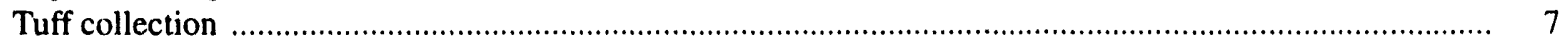

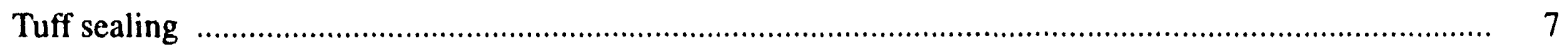

Tuff transportation and storage .......................................................................................................... 8

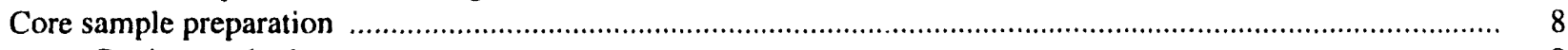

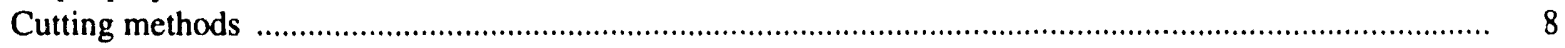

Variations in procedure due to sealing ............................................................................................. 9

Variations in procedure due to test method ............................................................................................ 9

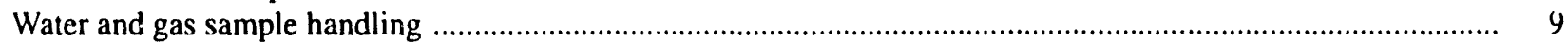

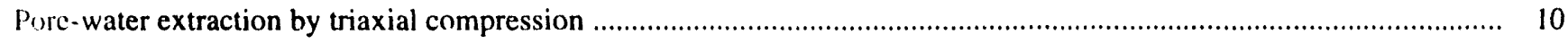

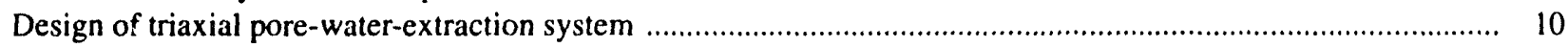

Operation of triaxial pore-water-extraction system .................................................................................. 11

Mechanical data for triaxial compression .......................................................................................... 12

Pore-water extraction by one-dimensional compression ........................................................................... 17

Design of one-dimensional pore-water-extraction system ................................................................... 17

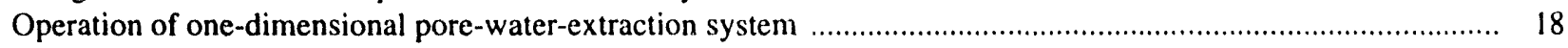

Mechanical data for one-dimensional compression ............................................................................... 19

Additional data for pore-water extraction using gas injection ............................................................................... 24

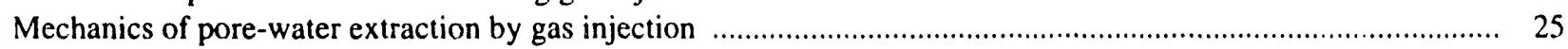

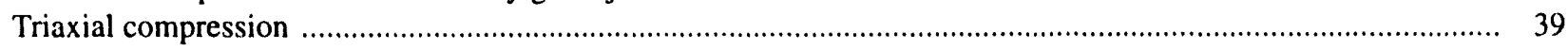

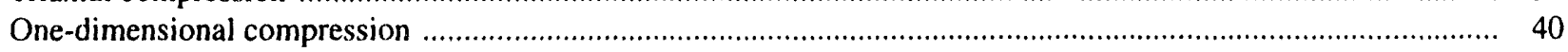

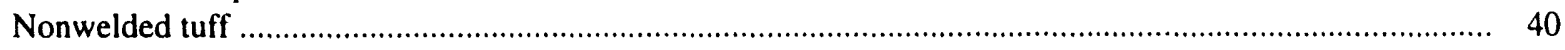

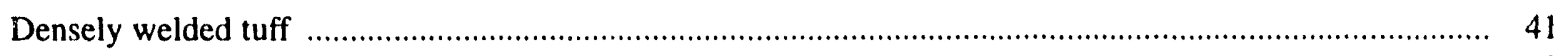

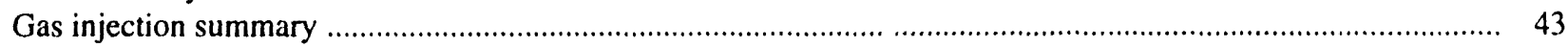

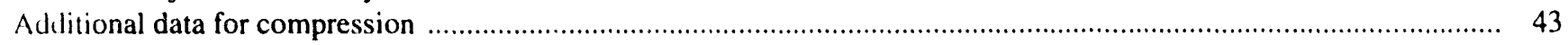

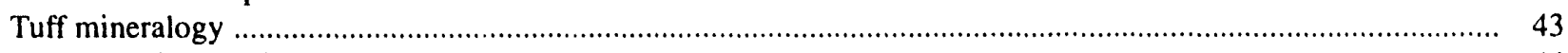

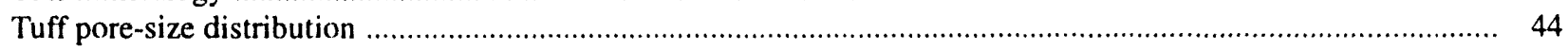

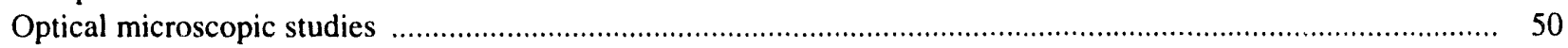

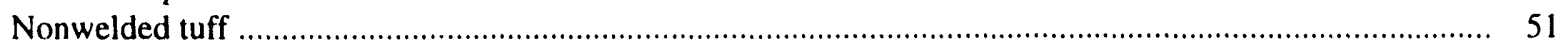

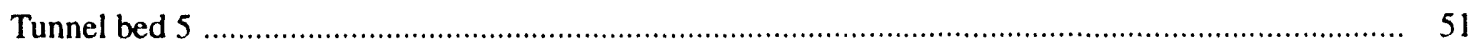

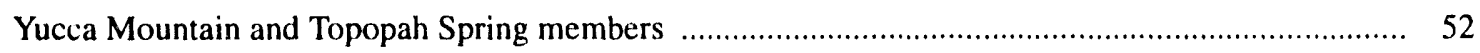

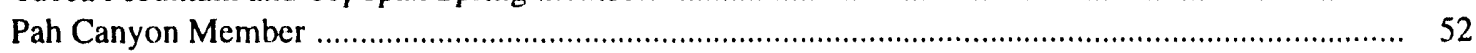

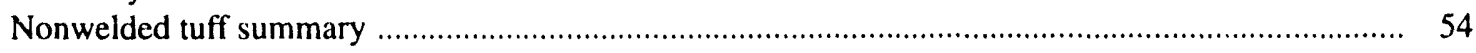

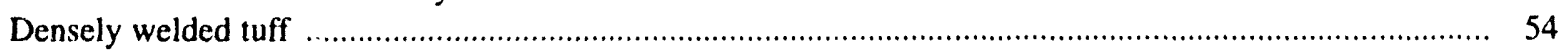

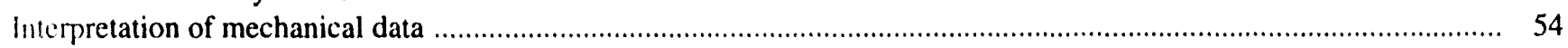

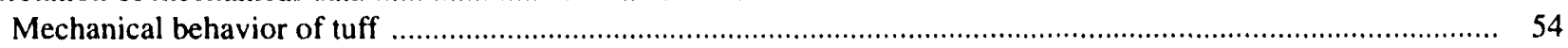

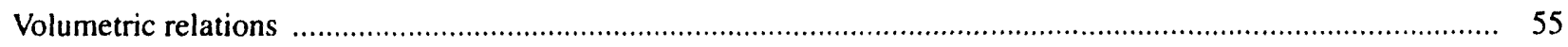

Comparison between triaxial and one-dimensional compression ........................................................... 56

Discussion 
Advantages of one-dimensional compression

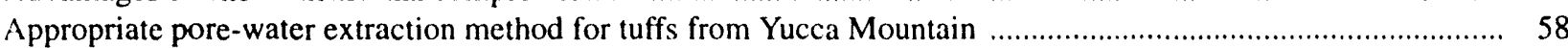

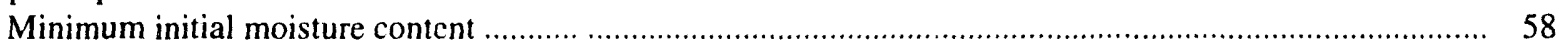

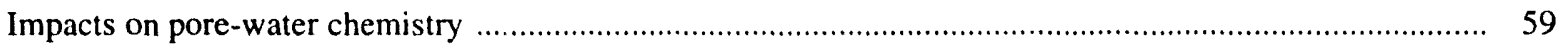

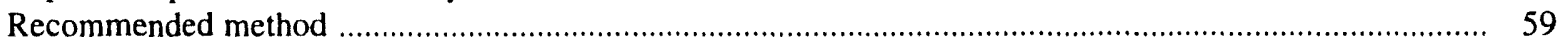

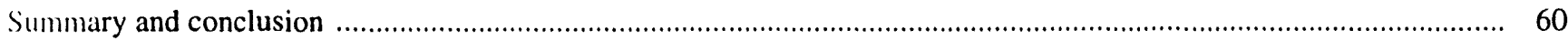

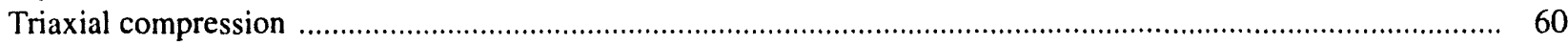

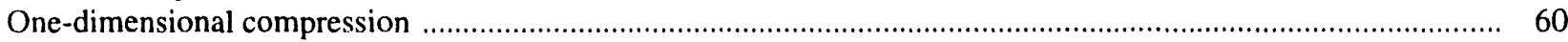

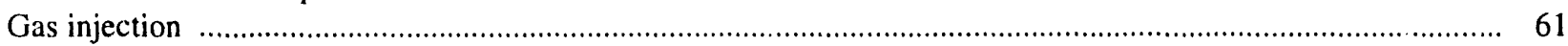

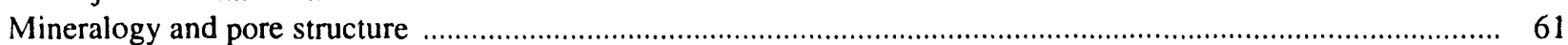

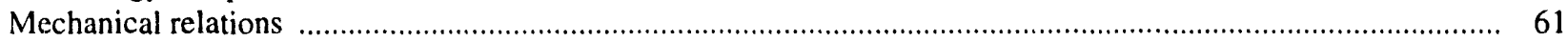

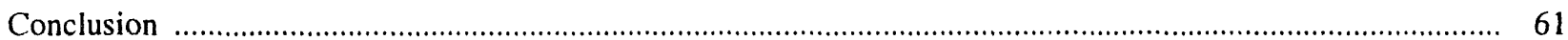

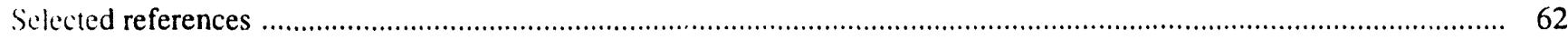

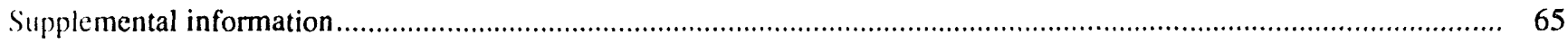

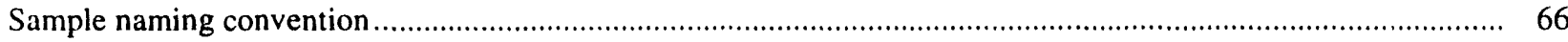

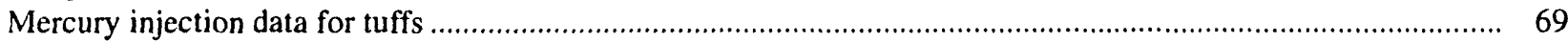

\section{FIGURES}

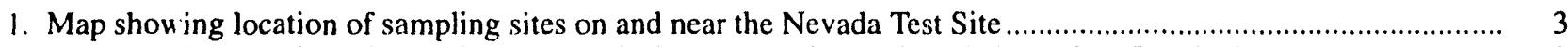

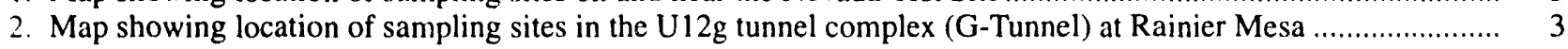

3. Generalized geologic relations at Yucca Mountain and Rainer Mesa ..........................................................

4-9. Diagrams showing:

4. Analog compression model at initial conditions

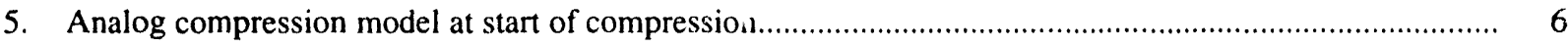

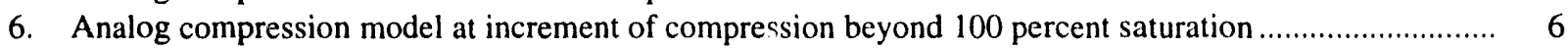

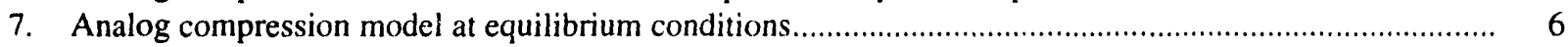

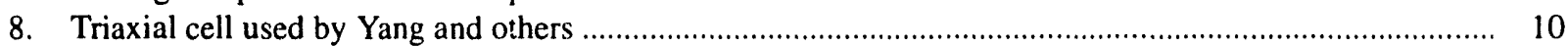

10-14. Graphs showing:

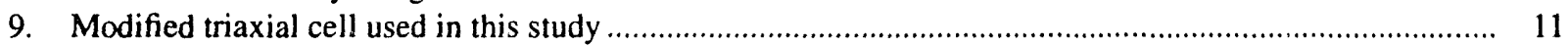

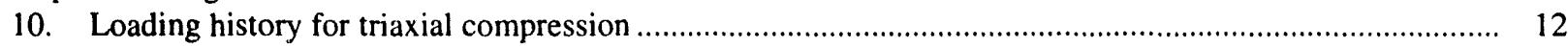

11. Relation between axial stress and axial strain for triaxial compression of a nonwelded tuff sample UZ4-190

12. Relation between initial moisture content and volume of pore water extracted from cores using triaxial compression without gas injection.....

13. Relation between initial moisture content and volume of pore water extracted from cores using triaxial compression with gas injection.

14. Relation between initial moisture content and pore-water extraction success for cores tested using triaxial compression

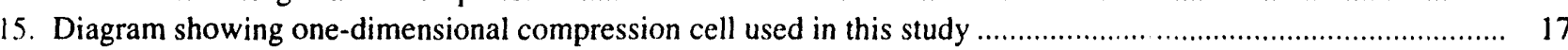

16. Diagram showing drainage plates used in one-dimensional compression cell.................................................. 18

17-41. Graphs showing:

17. Loading history for one-dimensional compression of sample GT-LD-AC2-63

18. Relation between axial stress and axial strain for one-dimensional compression of a nonwelded tuff sample UZ5-335.

19. Relation between axial stress and axial strain for one-dimensional compression of a densely welded tuff sample GT-LD-AC2-63

20. Relation between initial moisture content and volume of pore water extracted from cores using one-dimensionai compression with gas injection.....

21. Relation between initial moisture content and volume of pore water extracted from densely welded cores using one-dimensional compression with gas injection.

22. Relation between initial moisture content and pore-water extraction success for cores tested using one-dimensional compression 
23. Volume of pore water extracted versus gas injection duration from tuff cores using triaxial compression with gas injection

24. Volume of pore water extracted versus gas injection duration from sample UZ4-238 using triaxial compression with gas injection

25. Volume of pore water extracted versus gas injection duration from tuff cores using one-dimensional compression with gas injection

26. Volume of pore water extracted versus gas injection duration from sample GT-LD-AC2-62 using one-dimensional compression with gas injection......

Volume of pore water collected by cold trap versus gas volume injected from sample GT-DD-A-10

during one-dimensional compression with gas injection

28. Pore-size distribution for sample UZ5-335

29. Pore-size distribution for sample GTO-JJ-DB-1 A-2-1

30. Pore-size distribution for sample GT-LD-AC2-55

31. Pore-size distribution for sample GT-LD-AC2-62.

32. Relative density of fractures in phenocrysts in nonwelded tuff cores tested using triaxial compression

33. Deformational behavior of tuff cores during compression

34. Relation between axial strain and volume of pore water extracted from sample GT-EX-DH-3 using one-dimensional compression

35. The effect of increasing axial stress on core moisture content for cores tested using one-dimensional compression.

6. Total volume of pore water extracted from nonwelded tuff cores using triaxial and one-dimensional compression

37. Recommended loading history for one-dimensional compression of densely welded and nonwelded tuff cores

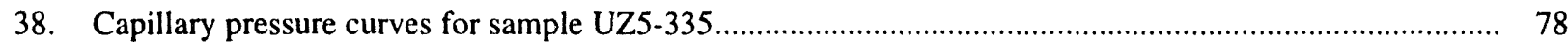

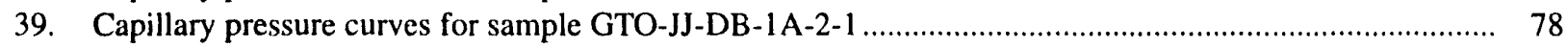

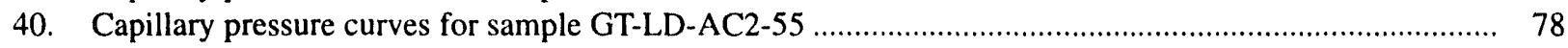

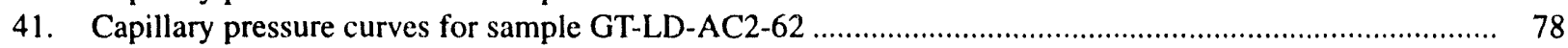

\section{TABLES}

1. Mechanical data for triaxial compression

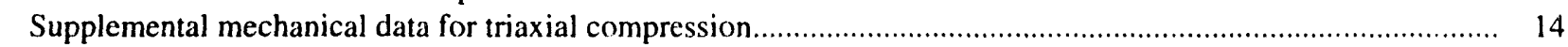

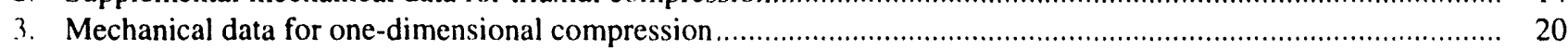

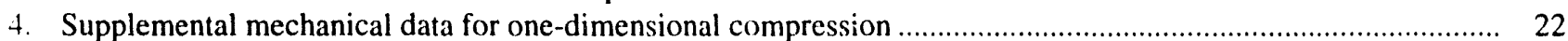

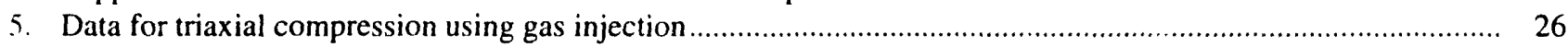

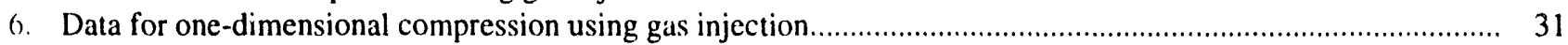

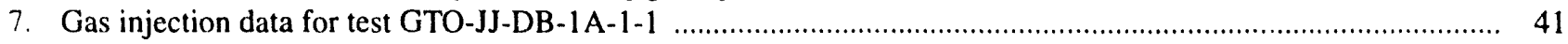

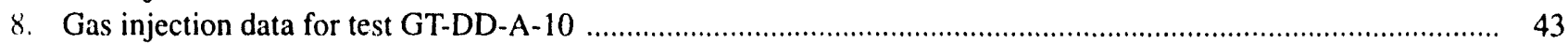

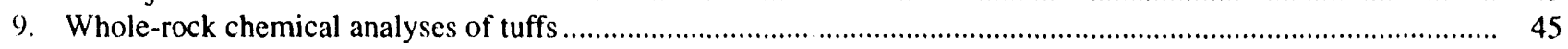

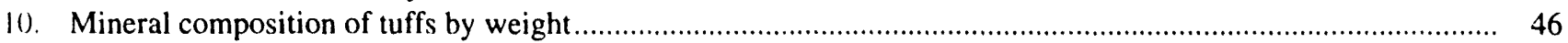

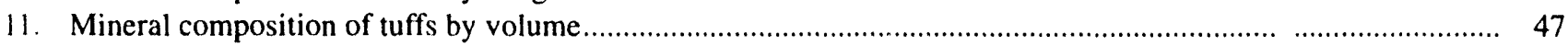

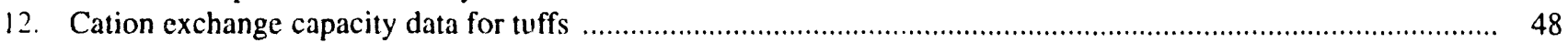

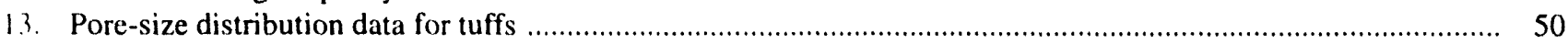

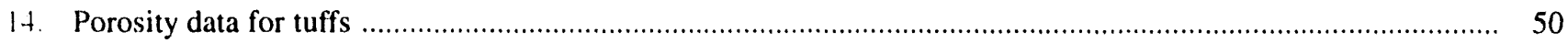

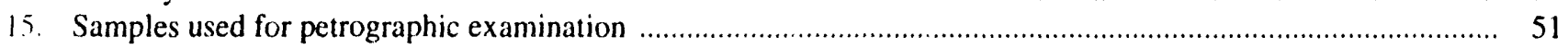

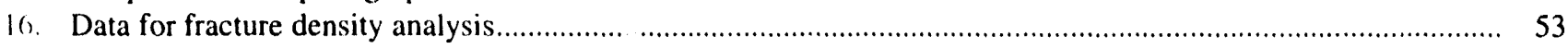

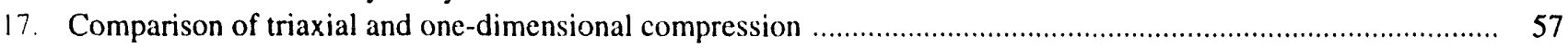

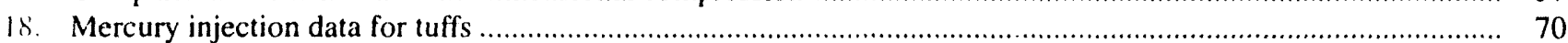




\section{CONVERSION FACTORS AND VERTICAL DATUM}

\begin{tabular}{|c|c|c|}
\hline Multiply & By & To obtain \\
\hline angstrom (A) & $3.937 \times 10^{-9}$ & inch \\
\hline centimeter $(\mathrm{cm})$ & $3.937 \times 10^{-1}$ & inch \\
\hline cubic centimeter $\left(\mathrm{cm}^{3}\right)$ & $6.102 \times 10^{-2}$ & cubic inch \\
\hline dyne & $2.248 \times 10^{-6}$ & pound, force \\
\hline $\operatorname{gram}(\mathrm{g})$ & $2.205 \times 10^{-3}$ & pound, mass \\
\hline gram per cubic centimeter $\left(\mathrm{g} / \mathrm{cm}^{3}\right)$ & $3.613 \times 10^{-2}$ & pound per cubic inch \\
\hline kilometer $(\mathrm{km})$ & $6.214 \times 10^{-1}$ & mile \\
\hline kilonewton $(\mathrm{kN})$ & $2.248 \times 10^{2}$ & pound, force \\
\hline kilopascal $(\mathrm{kPa})$ & $1.450 \times 10^{-1}$ & pound per square inch \\
\hline liter (l) & $3.531 \times 10^{-2}$ & cubic foot \\
\hline meganewton (MN) & $2.248 \times 10^{5}$ & pound, force \\
\hline megapascal (MPa) & $1.450 \times 10^{2}$ & pound per square inch \\
\hline meter $(\mathrm{m})$ & 3.281 & foot \\
\hline micrometer $(\mu \mathrm{m})$ & $3.937 \times 10^{-5}$ & inch \\
\hline milligram (mg) & $2.205 \times 10^{-6}$ & pound \\
\hline milliliter (mL) & $3.531 \times 10^{-5}$ & cubic foot \\
\hline millimeter $(\mathrm{mm})$ & $3.937 \times 10^{-2}$ & inch \\
\hline newton $(\mathrm{N})$ & $2.248 \times 10^{-1}$ & pound, force \\
\hline
\end{tabular}

Degree Celsius $\left({ }^{\circ} \mathrm{C}\right)$ may be converted to degree Fahrenheit $\left({ }^{\circ} \mathrm{F}\right)$ by using the following equation: ${ }^{\circ} \mathrm{F}=9 / 5\left({ }^{\circ} \mathrm{C}\right)+32$.

Degree Fahrenheit $\left({ }^{\circ} \mathrm{F}\right)$ may be converted to degree Celsius $\left({ }^{\circ} \mathrm{C}\right)$ by using the following equation: ${ }^{\circ} \mathrm{C}=5 / 9\left({ }^{\circ} \mathrm{F}-32\right)$. 


\title{
Pore-Water Extraction from Unsaturated Tuff by Triaxial and One-Dimensional Compression Methods, Nevada Test Site, Nevada
}

\author{
By T.E. Mower, J.D. Higgins, I.C. Yang, and C.A. Peters
}

\begin{abstract}
Study of the hydrologic system at Yucca Mountain, Nevada, requires the extraction of pore-water samples from welded and nonwelded, unsaturated tuffs. Two compression methods (triaxial compression and one-dimensional compression) were examined to develop a repeatable extraction technique and to investigate the effects of the extraction method on the original pore-fluid composition.
\end{abstract}

A commercially available triaxial cell was modified to collect pore water expelled from tuff cores. The triaxial cell applied a maximum axial stress of $193 \mathrm{MPa}$ and a maximum confining stress of $68 \mathrm{MPa}$. Results obtained from triaxial compression testing indicated that pore-water samples could be obtained from nonwelded tuff cores that had initial moisture contents as small as 13 percent (by weight of dry soil). Injection of nitrogen gas while the test core was held at the maximum axial stress caused expulsion of additional pore water and reduced the required initial moisture content from 13 to 11 percent. Experimental calculations, together with experience gained from testing moderately welded tuff cores, indicated that the triaxial cell used in this study could not apply adequate axial or confining stress to expel pore water from cores of densely welded tuffs. This concern led to the design, fabrication, and testing of a one-dimensional compression cell.

The one-dimensional compression cell used in this study was constructed from hardened 4340-alloy and nickel-alloy steels and could apply a maximum axial stress of $552 \mathrm{MPa}$. The major components of the device include a corpus ring and sample sleeve to confine the sample, a piston and base platen to apply axial load, and drainage plates to transmit expelled water from the test core out of the cell. One-dimensional compression extracted pore water from nonwelded tuff cores that had initial moisture contents as small as 7.6 percent; pore water was expelled from densely welded tuff cores that had initial moisture contents as small as 7.7 percent. Injection of nitrogen gas at the maximum axial stress did not produce additional pore water from nonwelded tuff cores, but was critical to recovery of pore water from densely welded tuff cores. Gas injection reduced the required initial moisture content in welded tuff cores from 7.7 to 6.5 percent.

Based on the mechanical ability of a pore-water extraction method to remove water from welded and nonwelded tuff cores, one-dimensional compression is a more effective extraction method than triaxial compression. However, because the effects that onedimensional compression has on pore-water chemistry are not completely understood, additional testing will be needed to verify that this method is suitable for porewater extraction from Yucca Mountain tuffs.

\section{INTRODUCTION}

The hydrologic system in the unsaturated tuff at Yucca Mountain, Nevada, is being evaluated for the U.S. Department of Energy by the Yucca Mountain Project Branch of the U.S. Geological Survey as a potential site for a high-level radioactive-waste repository. Part of this investigation includes a hydrochemical study that is being made to assess characteristics of the hydrologic system such as: traveltime, direction of flow, recharge and source relations, and types and magnitudes of chemical reactions in the unsaturated tuff. In addition, this hydrochemical information will be used in the study of the dispersive and corrosive effects of unsaturated-zone water on the radioactive-waste storage canisters. This report examines methods used to obtain representative, uncontaminated samples of pore water from tuffs that have a small initial moisture content.

\section{Purpose and Scope}

This report describes the design and validation of laboratory experimental procedures for extracting representative samples of uncontaminated pore water from welded and nonwelded, unsaturated tuffs from the Nevada Test Site. These procedures include the use of a standard triaxial compression cell and a one- 
dimensional compression cell specifically designed and fabricated for this investigation. The two purposes of this study were: (1) to develop a repeatable technique for extracting pore water from cores of unsaturated, nonwelded and densely welded tuffs, and (2) to investigate the effects of the extraction method on the original pore-fluid composition. This report documents the development of the extraction technique and equipment. The water chemistry investigation currently (1993) is in progress; results will be published separately. Also, pore-gas samples were collected for use in another, related study. The volume of gas collected as a result of compression is reported herein; however, gas analyses and interpretation are beyond the scope of this report.

A total of 17 triaxial- and 32 one-dimensionalcompression tests were done to determine the optimum stress and duration of compression for efficient extraction of pore water from core samples of welded and nonwelded tuffs. Three primary factors were considered in the development of the testing methods:

1. Factors that govern the amount and rate of compression of the sample such as: tuff mineralogical composition, texture, and degree of welding,

2. Factors that could cause alteration of the porewater chemistry during compression including: tuff mineralogical composition, duration and rate of loading, potential for core temperature increase, and exposure time of pore water to newly created mineral surfaces, and

3. Water volume required for chemical analysis.

In addition to the compression tests, several studies were done to determine the effects of the extraction methods on the original fluid composition: (1) monitoring of core temperature during compression, (2) quantitative mineralogical analysis of core specimens, (3) pore-size determination using mercury injection, and (4) petrographic analysis of thin sections for core textural changes. In the second phase of this research, these studies will be correlated with measured variations in the chemical composition of extracted pore water to develop $\mathrm{in}$ extraction procedure that produces the smallest amount of change in the chemical composition of the pore water.

Data presented in this report were collected for the purpose of developing and validating the porewater-extraction methods. Interpretation of the data with regard to characterization of the hydrologic regime at Yucca Mountain is beyond the scope of this report.

\section{Acknowledgments}

The authors wish to thank the U.S. Bureau of Reclamation and Mr. Joseph Prizio of that agency for their large contribution to the design and construction of the one-dimensional compression cell and their interest and support in development of the testing procedures.

\section{Location of Sample Sites}

Core specimens used for pore-water extraction were collected from three sources: (1) vertical boreholes on Yucca Mountain, (2) horizontal boreholes in the U12g tunnel complex (G-Tunnel) at Rainier Mesa, and (3) laboratory cores cut from blocks of blast rubble from G-Tunnel. These sample sites are located on or adjacent to the Nevada Test Site (NTS), which is about $105 \mathrm{~km}$ northwest of Las Vegas, Nevada (fig. 1). A detailed, schematic drawing of the section of G-Tunnel used for sample collection is presented in figure 2 .

The sample naming convention used in this report was designed only to reduce the length of sample names while maintaining an appropriate and unique name for each test specimen. The naming system is not designed to include the complete borehole name in each sample name nor is it a standard system used in naming samples from the NTS. A complete description of the sample naming convention used in this report is included in the section "Supplemental Information."

\section{General Geologic Relations at the Nevada Test Site}

Most of the tuffs present at the NTS were erupted from the Timber Mountain-Oasis Valley caldera complex between 9 and 16 million years ago (Byers and others, 1976). The caldera complex is located in and adjacent to the northwest part of the NTS and was the source of the tuffs at Yucca Mountain and Rainier Mesa. Detailed discussions of NTS geology can be found in Lipman and others (1966) and Byers and others (1976). Simplified stratigraphic columns of Yucca Mountain and Rainier Mesa are presented in figure 3. Note that, at Yucca Mountain, divisions in tuff degree of welding do not directly correspond with lithologic unit boundaries. Refer directly to the data tables presented later in this report to determine the degree of welding for any individual sample. Pore-waterextraction tests were done on the following lithologic units from Yucca Mountain (all from the Paintbrush

2 Pore-Water Extraction from Unsaturated Tuff by Triaxial and One-Dimensional Compression Methods, Nevada Test Site, Nevada 
Tuff): Tiva Canyon Member, Yucca Mountain Member, Pah Canyon Member, and Topopah Spring Member. From G-Tunnel in Rainier Mesa, pore water was extracted from the Grouse Canyon Member of the Belted Range Tuff and from Tunnel bed 5 of the Grouse Canyon Member.

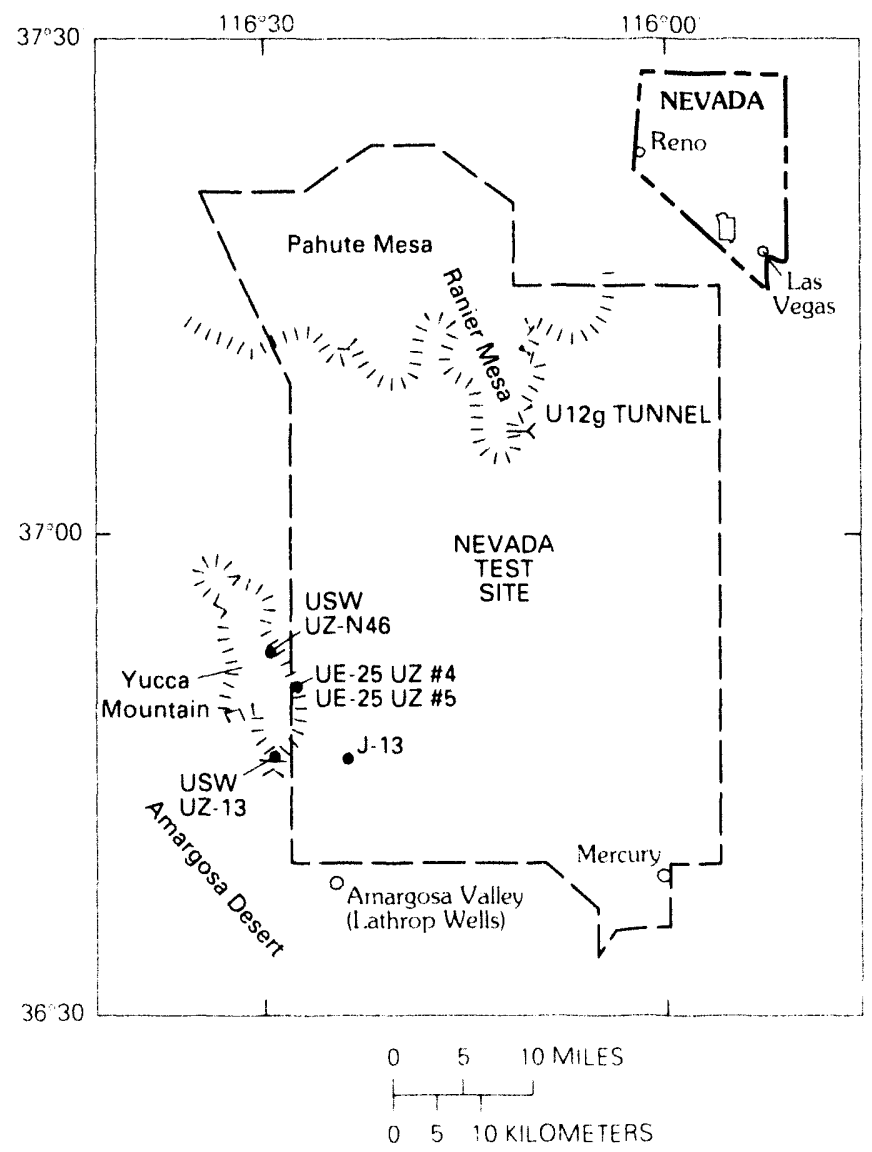

Figure 1. Location of sampling sites on and near the Nevada Test Site. Samples were obtained from vertical boreholes USW UZ-N46, USW UZ-13, UE-25 UZ \#4, UE-25 $U Z \# 5$, and J-13. Samples were collected from horizontal boreholes inside of the U12g Tunnel complex.

\section{REVIEW OF PREVIOUS WORK}

\section{Compression Methods}

Compression methods have been used in the study of natural und man-made materials--both for the study of the solid phase as well as for pore-water extraction. Investigations of sediment diagenesis (especially the compaction of clays) have used compression methods extensively. Rieke and Chilingarian (1974) and Singer and Müller (1983) presented sum- maries of the uses of compression methods in the study of sediment diagenesis.

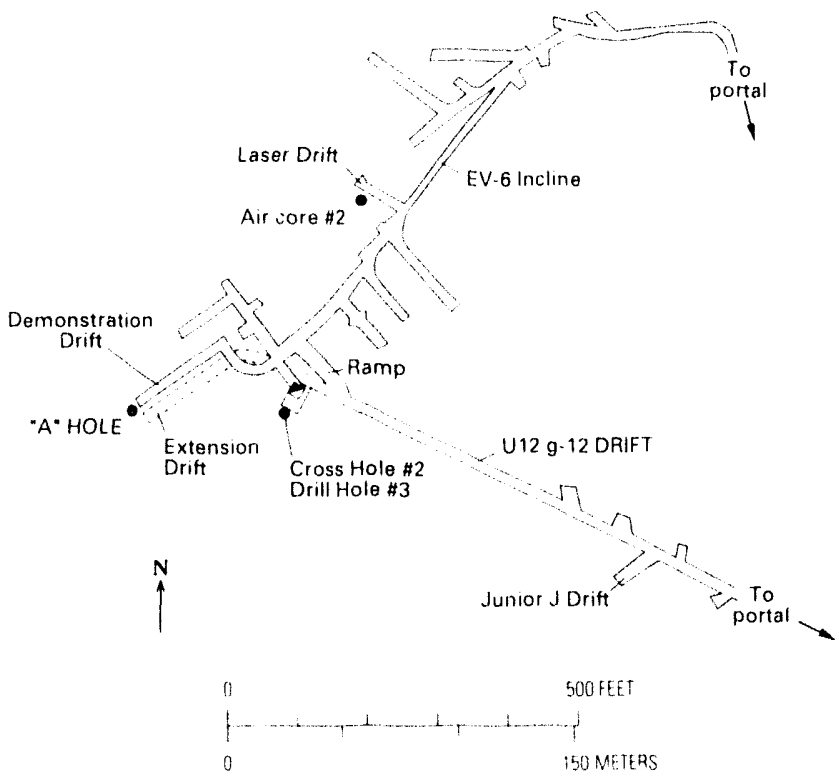

Figure 2. Location of sampling sites in the U12g tunnel complex (G-Tunnel) at Rainier Mesa.

Manheim (1974) listed many of the types of squeezing devices used for compressing ocean sediment for the study of interstitial water. Although there are many squeezing devices, most of them have two characteristics in common: (1) they are designed for use at pressures less than $34 \mathrm{MPa}$, and (2) they isolate the extracted water from contact with the atmosphere. The technique for isolating the extracted water from the atmosphere was adopted by Sayre (1985) (see section "Compression Methods for Pore-Water Extraction") and also was used in the experiments discussed in this report.

Compression devices are often used to study properties of rocks under high temperatures and pressures. Baidyuk (1967) described 12 different devices used to apply hydrostatic (axial stress equal to confining stress) stresses as large as 1,010 MPa and temperatures up to $800^{\circ} \mathrm{C}$. These devices, however were designed to study changes in rock strength properties and not for collection of pore water.

Compression methods are used in research on man-made materials. Barneyback and Diamond (1981) used a high-pressure device to extract pore fluid from hardened cement pastes to study the reaction between pore fluid and support steel in reinforced concrete. This device was able to apply a maximunı axial stress of about $550 \mathrm{MPa}$ to a sample that was about $45 \mathrm{~mm}$ in length and $53 \mathrm{~mm}$ in diameter. L.J. Struble 
YUCCA MOUNTAIN

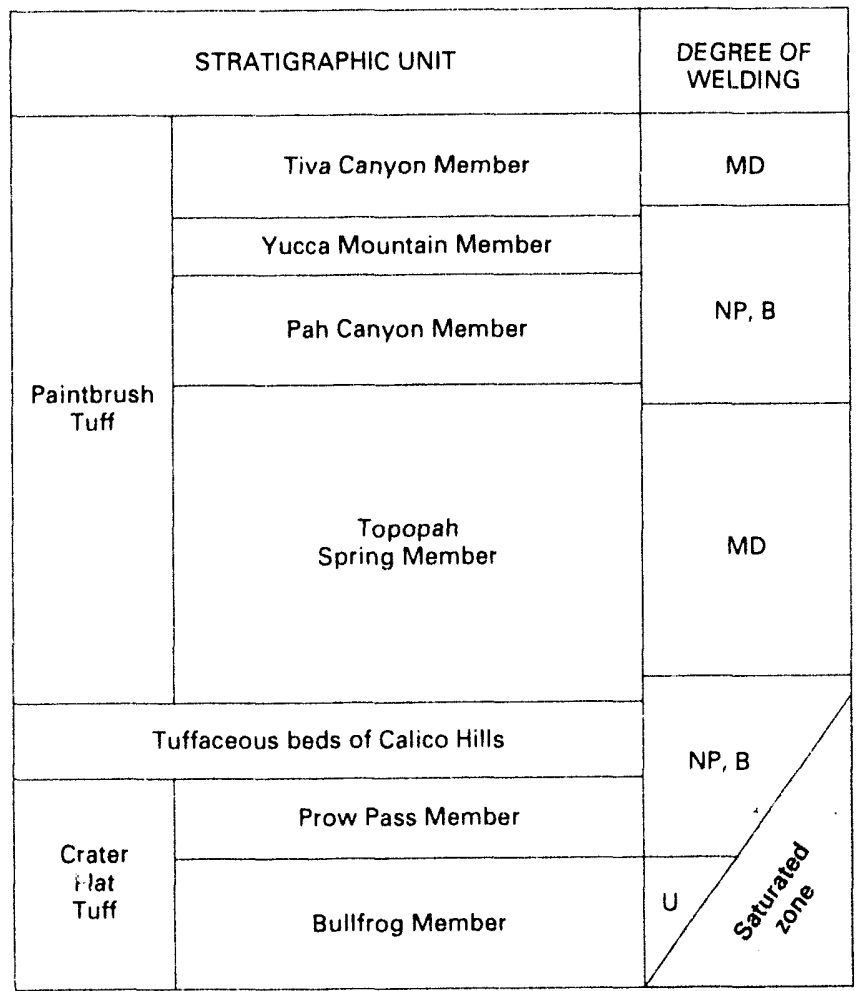

RAINIER MESA

\begin{tabular}{|c|c|c|}
\hline \multicolumn{2}{|c|}{ STRATIGRAPHIC UNIT } & \multirow{2}{*}{$\begin{array}{c}\text { DEGREE OF } \\
\text { WELDING } \\
\text { MD }\end{array}$} \\
\hline $\begin{array}{c}\text { Timber } \\
\text { Mountain } \\
\text { Tuff }\end{array}$ & Rainier Mesa Member & \\
\hline \multirow{5}{*}{$\begin{array}{c}\text { Paintbrush } \\
\text { Tuff }\end{array}$} & Bedded tuff & NP, B \\
\hline & Tiva Canyon Member & MD \\
\hline & Bedded tuff & NP, B \\
\hline & Stockade Wash Member & NP \\
\hline & Bedded tuff & NP, B \\
\hline \multirow{6}{*}{$\begin{array}{c}\text { Belted } \\
\text { Range } \\
\text { Tuff }\end{array}$} & Grouse Canyon Member & MD \\
\hline & Tunnel bed 5 & $N P, B$ \\
\hline & Tunnel bed 4 & $N P, B$ \\
\hline & Tunnel bed 3 & $N P, B$ \\
\hline & Tunnel bed 2 & $N P, B$ \\
\hline & Tunnel bed 1 & $N P, B$ \\
\hline
\end{tabular}

Figure 3. Generalized geologic relations at Yucca Mountain and Rainer Mesa. MD, moderately welded; NP, nonwelded to partially welded; B, bedded; U, undifferentiated. Thicknesses not to scale. Modified from: Gibbons and others (1963), Montazer and Wilson (1984), and Zimmerman and Finley (1987).

(1988, National Institute for Standards and Technology, pers. comm.) and D.M. Roy (1988, Pennsylvania State University, pers. comm.) used similar, but slightly modified devices in concrete research. The die developed by Barneyback and Diamond (1981) served as a model for the one-dimensional compression cell discussed later in this report.

Although a large number of publications exist describing the use of compression methods, most of this information is not directly applicable to the prob. lem of extracting pore water from unsaturated tuffs. Most of the existing publications can be divided into two groups: (1) methods that focused on pore-water extraction but used only saturated, compressible, unconsolidated sediment, and (2) methods that compressed rocks but did not collect pore water. Neither group of publications provides much information that is relevant to the problem of pore-water extraction from unsaturated tuffs. Some published papers do, however, discuss the use of compression methods to extract pore water from unsaturated tuffs; these publications are reviewed in the section "Compression Methods for Pore-Water Extraction."

\section{Other Pore-Water-Extraction Methods}

Compression is not the only means available for the removal of pore water from sediments. Other methods for pore-water extraction include: centrifugation, vacuum distillation, dilution, high-pressure gas displacement, and immiscible displacement.

Pore water may be forced out of consolidated sediments by spinning samples in a high-speed centrifuge at speeds up to 20,000 rpm. Centrifugation of chalk was discussed by Edmunds and Bath (1976); Yang and others (1990) outlined centrifugation methods used for cores and broken fragments of NTS nonwelded tuff. The main disadvantage of centrifugation is the inability to monitor and sample pore water as it is expelled during the extraction process.

Vacuum distillation involves the drying of sediment or rock under a vacuum and the subsequent trapping of the expelled water vapor in a cold trap cooled to about $-78^{\circ} \mathrm{C}$ by a dry ice/alcohol slurry. Because vacuum distillation removes only pure water and leaves all dissolved constituents behind, this method of pore-water extraction is not useful when information 
about the dissolved ionic chemistry of the pore water is needed.

Forcing large volumes of distilled water through a rock sample to determine the original pore-water composition by dilution has two large disadvantages: (1) increased potential for reaction of mineral grains with introduced water, and (2) difficulty in obtaining accurate concentration measurements due to large errors associated with very low concentrations. Devine and others (1973) discussed the problems involved with dilution methods.

Pore water may be forced from rock by flowing inert gas at high pressures through the sample. Dropek and Levinson (1975) attempted to extract pore water from NTS tuff using argon at pressures of about $10 \mathrm{MPa}$, but had very small water recoveries $(3 \mathrm{~mL}$ or less). Although the low efficiency of this method eliminates it as a primary extraction technique, the injection of inert gas into a sample was used in this research as a supplemental method to extract additional water after a sample was compressed by triaxial or one-dimensional compression. .

Immiscible displacement can be used in conjunction with compression methods or centrifugation to drive pore water out of a sample. A viscous, hydrocarbon polymer (usually some type of epoxy plasticizer) is pushed through the sample by the force of compression or centrifugation; pore water is forced out of the sample ahead of the immiscible polymer. Immiscible displacement used with compression was discussed by Scholl (1963); immiscible displacement in conjunction with centrifugation was examined by Yang and others, 1990. Immiscible displacement is not an appropriate extraction method when pore-water chemistry information is needed for two reasons: (1) introduction of another fluid into the pore space may cause additional reactions with mineral grains, and (2) the displacement fluid may not be totally immiscible and may absorb water during the extraction process.

\section{Compression Methods for Pore-Water Extraction}

Three publications that describe pore-water extraction from unsaturated rock by compression have a direct bearing on the research presented in this report. Work done by Dropek and Levinson (1 275$)$ examined pore-water extraction from nonwelded tuffs from Rainier Mesa using triaxial compression. The use of triaxial compression for pore-water extraction from nonwelded, Yucca Mountain tuffs was extended and modified by Sayre (1985) and Yang and others (1988). (Note that the publication by Yang and others (1988) is very similar to, and based on, research presented by Sayre (1985). The U.S. Geological Survey report by Yang and others will be cited in the remainder of this report to avoid numerous dual references where information contained in both reports is cited.) These studies served as the starting point for the research presented in this report.

Work done by Dropek and Levinson (1975) was summarized in Yang and others (1988) and will not be repeated here. The report by Yang and others (1988) describes modifications made to a standard, commercially available, triaxial compression cell for porewater extraction. These moditications included: (1) redesigned, thicker end caps to withstand large axial pressures during long-duration tests, (2) wrapping the test specimen in Teflon to reduce the risk of contamination during pore-water extraction, and (3) collection of expelled water in syringes to eliminate contact between expelled water and the atmosphere. This modified triaxial compression cell was used for the initial porewater extraction tests described in this report; this device was further modified as discussed later in this report.

\section{Mechanics of Pore-Water Expulsion}

The process by which water is expelled from rocks during compression has been studied in detail by workers investigating the diagenesis of recently deposited sediments (Rieke and Chilingarian, 1974). A simple physical model of compression characterizes a unit volume of rock as a cylinder containing air, water, and a spring (figs. 4-7). The spring represents the compressible rock skeleton; the air and water represent the fluids in the pore space; and the drain and vent represent the pore size. The diagram in figure 4 shows the initial state of the analog system. A tightly fitted metal plate seals the pore air and water in the cylinder; the applied load is zero and the water pressure is hydrostatic (equal to the depth of the water in the cylinder).

As load is applied to the plate, the spring compresses and air is expelled through the one-way vent; the water saturation (degree of saturation) of the model increases. Eventually, all the air is removed (fig. 5); this state is analogous to the rock being 100 percent water-saturated. As the spring continues to compress in response to the applied load, the plate continues to descend in the next increment of compression (fig. 6). The pore water instantaneously bears all the load-as is indicated by the rise of water in the piezometer. Water moves out of the drain in response to the pressure gradient, and the water pressure decreases while the spring carries more of the load. (The rate at which 


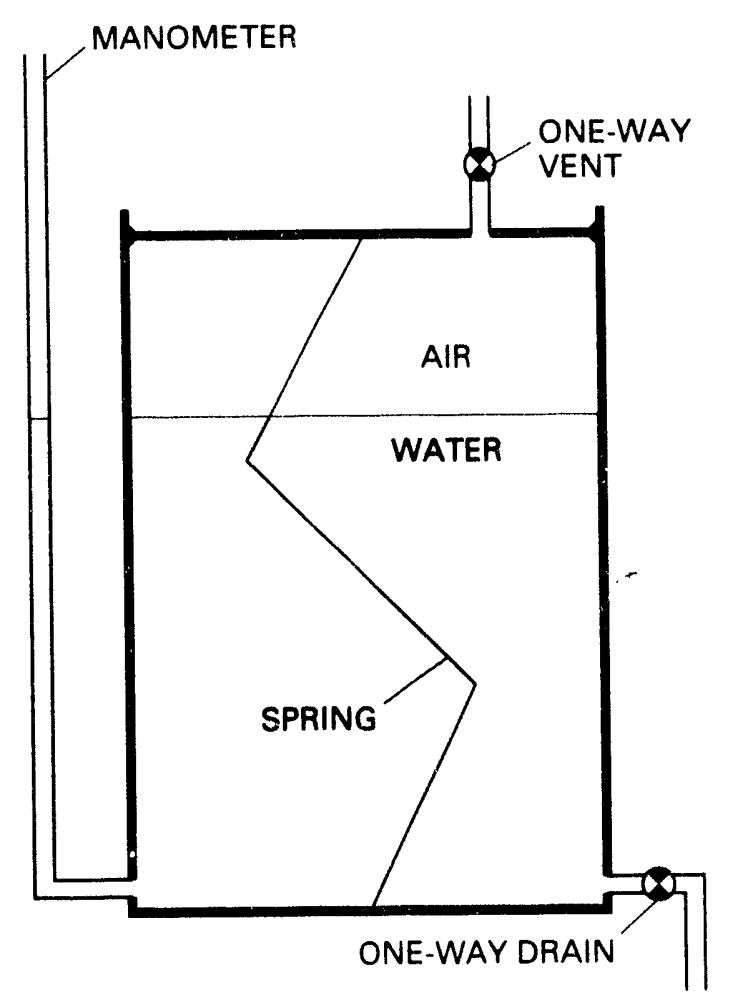

Flgure 4. Analog compression model at initial conditions.

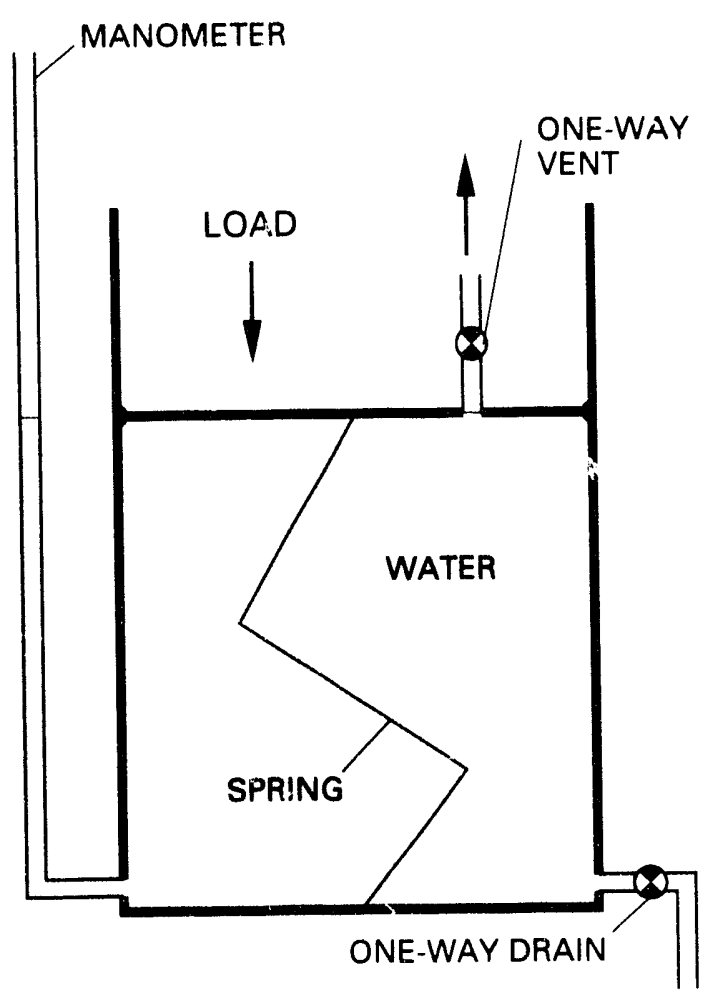

Figure 5. Analog compression model at start of compression.

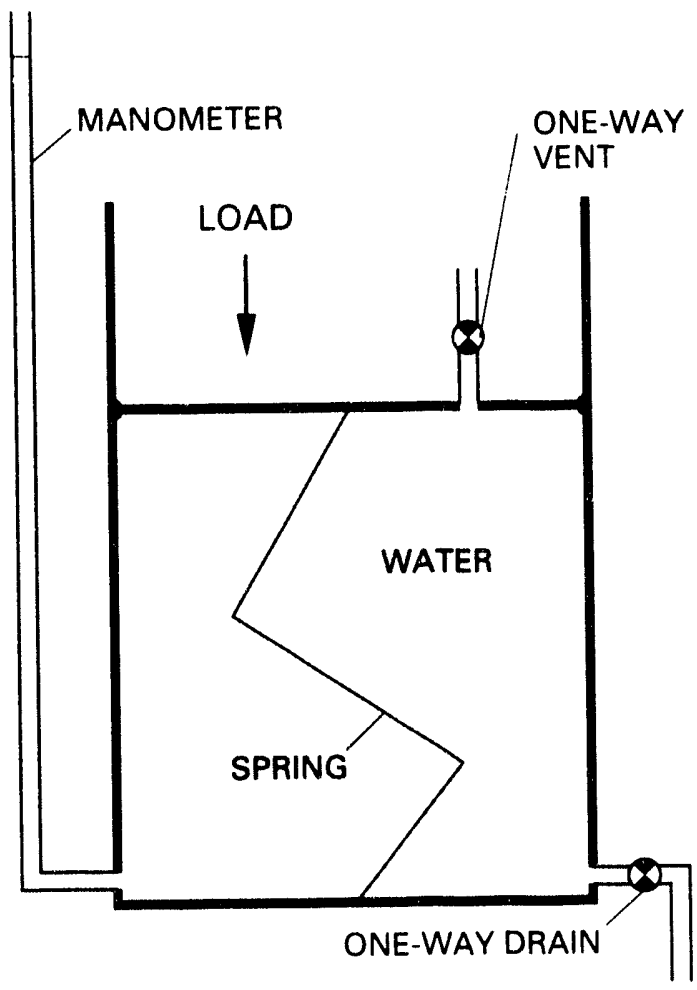

Figure 6. Analog compression model at increment of compression beyond 100 percent saturation.

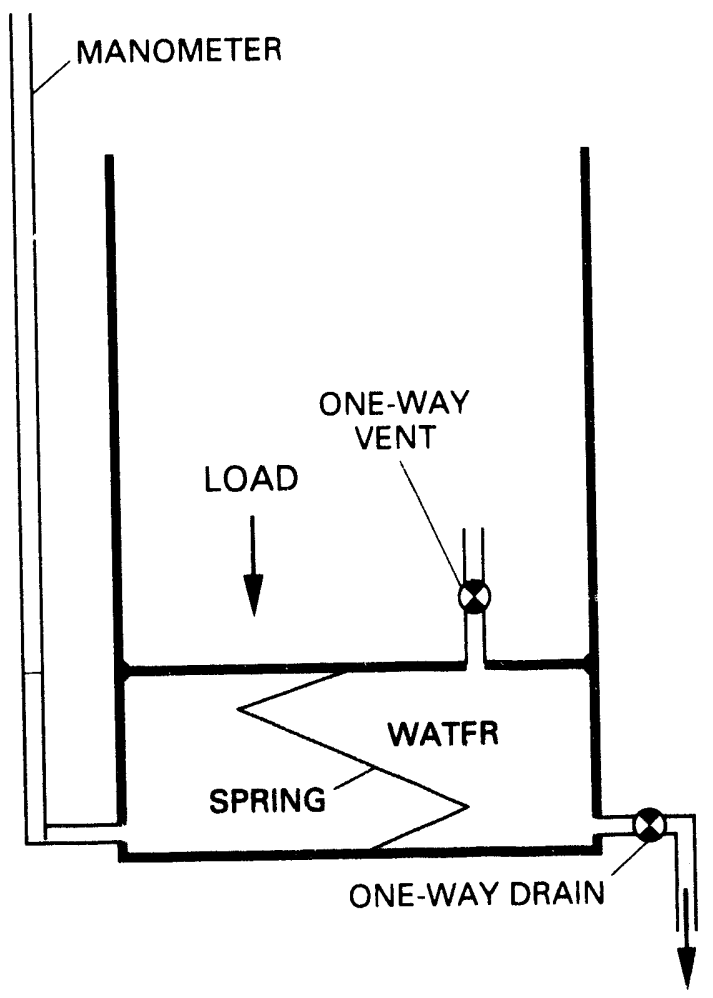

Figure 7. Analog compression model at equilibrium conditions. 
the water moves and the rate at which the pressure measured by the nanometer decreases depends on the hydraulic conductivity of the rock-a factor not included in this simple model.) When the spring and the applied load are in equilibrium (fig. 7), motion of the plate stops, expulsion of water ceases, and water pressure returns to hydrostatic. Any further increase in the applied load repeats the cycle shown in figures 6 and 7. Additional water is expelied as the system again returns to equilibrium.

The actual process of compression in rock is more complex but, in principle, is similar to the analog model. The mechanics of compacting the rock skeleton, represented by the compressing spring, includes such processes as: grain reorientation, grain deformation, and microfracturing of the rock matrix. Properties of a porous medium, such as capillary attraction and hydraulic conductivity, are not accounted for by the spring in the analog model. During the initial stages of compression when the rock is partially saturated, only air is expelled as compression progresses; capillary forces hold the water in the pores until the pore system is fully saturated. The rate at which water is expelled is controlled by the hydraulic conductivity of the rock, which is, in turn, affected by changes in the rock matrix caused by compression. For the purposes of porewater extraction, the key point is that once the rock has been compressed to reach 100 percent saturation, additional compression will cause water expulsion.

\section{SAMPLE HANDLING AND PREPARATION}

Before beginning a detailed explanation of the methods used for pore-water extraction, a discussion of sample handling and preparation is given. Procedures used in sample collection, sealing, transportation, storage, and preparation for testing can have an effect on the volume and ionic composition of the extracted pore water.

\section{Tuff Sample Handling}

Sample handling methods were designed to maintain original core moisture conditions to minimize the effects of sample handling on the extracted water.

\section{Tuff Collection}

Core specimens used for pore-water extraction were collected from three sources: (1) vertical boreholes on Yucca Mountain, (2) horizontal boreholes in the U12g tunnel complex (G-Tunnel) at Rainier Mesa, and (3) laboratory cores cut from blocks of blast rubble from G-Tunnel. Refer to figures 1 and 2 for the locations of the sample sites. Cores from vertical boreholes on Yucca Mountain and from horizontal boreholes in G-Tunnel were collected using conventional air-coring methods. Cores from vertical boreholes UE-25 UZ \#4 and UE-25 UZ \#5 were collected and sealed in October 1984, and November 1984, respectively. Cores from horizontal boreholes Air Core \#2 (AC2), Cross Hole \#2 (XH2), and Drill Hole \#3 (DH3) from G-Tunnel were collected and sealed during May through July 1988. Cores from the horizontal borehole " $\mathrm{A}$ " were collected and sealed in July 1989. Rubble blocks from G-Tunnel were generated by drift excavatior. using powder blasting explosives (IRECO Hercodyne 365). (Blast explosive holes were drilled with air in nonwelded tuff and with water in densely welded tuff.) Rubble blocks ranged in size from $20 \mathrm{~cm} \times 20 \mathrm{~cm} \times 20 \mathrm{~cm}$ to $60 \mathrm{~cm} \times$ $60 \mathrm{~cm} \times 40 \mathrm{~cm}$ and were collected and sealed in June 1988. After appropriate sealing, transportation, and storage (see following sections), the blocks were aircored in the U.S. Bureau of Reclamation Earth Mechanics Laboratory at the Denver Federal Center in December 1988. All cores used in pore-waterextraction testing had a nominal diameter of $61 \mathrm{~mm}$.

\section{Tuff Sealing}

Three sealing methods were used after cores were collected to preserve original moisture conditions: aluminum foil and beeswax, split PVC (polyvinyl chloride) pipe, or Lexan (polycarbonate) liner. Aluminum foil/beeswax sealing involved wrapping intact core segments in heavy-grade aluminum foil and sealing the foil with melted beeswax until a thick (about $3 \mathrm{~mm}$ ) coat was achieved. Intact core segments and core fragments sealed using PVC pipe were placed inside Schedule 40 PVC pipe that had been cut in half along its length. PVC end caps were placed over the ends of the pipe. The pipe ends and longitudinal joints were sealed with tape and beeswax. Lexan liner was used inside the inner core barrel to directly contain the core during coring. Upon completion of a core $\mathrm{rin}$, the core and liner were removed together. Any excess liner was then cut off and the ends of the liner were covered by flexible plastic caps that were sealed to the liner using tape and beeswax.

No single sealing method is without disadvantages. Aluminum foil/beeswax sealing allows handling and direct observation of the cores only if they are unwrapped. Handling unsealed cores creates the potential for evaporation of pore water during processing. Because the aluminum foil can be formed to the contours of each individual core segment, there is little air space between the foil and the core for water evap- 
oration and subsequent condensation after ih: core is sealed. Use of Lexan liner reduces processing time and allows viewing of the core (Lexan is clear) but leaves an air gap (about $2 \mathrm{~mm}$ ) between the core and the liner. PVC pipe leaves a similar air gap. Moisture from the core can migrate out of the core, evaporate, and condense on the interior of the liner; most of this moisture remains on the liner when the core is removed for test preparation and is lost. Sealing samples using PVC requires core handling - which may permit dryingand allows condensation during storage and, so, is the least preferred of the three sealing methods. PVC sealing was not used as of 1990 in sample sealing at the NTS; however, some cores collected from Yucca Mountain boreholes UE-25 UZ \#4 and UE-25 UZ \#5 were sealed in PVC. Cores sealed in PVC were avoided as much as possible during pore-waterextraction testing. Rapid processing and sealing in aluminum foil and beeswax may provide the best method of moisture preservation of these three sealing methods.

Cores collected from boreholes $\mathrm{AC} 2$ and $\mathrm{XH} 2$ in G-Tunnel were sealed in aluminum foil and beeswax; cores collected from boreholes A and DH3 were sealed in Lexan liner. Rubble blocks from G-Tunnel were sealed in aluminum foil and beeswax. Most of the cores from Yucca Mountain that were used for compression testing had been sealed in aluminum foil and beeswax; cores that had been sealed in PVC pipe are noted later in this report. Cores collected by dry coring of rubble blocks in the laboratory were sealed using the aluminum foil and beeswax method except that a layer of plastic wrap was added beneath the foil to further enhance moisture preservation.

\section{Tuff Transportation and Storage}

Sealed cores and rubble blocks collected at the NTS were transported to the Denver Federal Center in an air conditioned van. Cores and blocks were stored in refrigerated and humidity-controlled lockers maintained at 4 to $10^{\circ} \mathrm{C}$ to inhibit evaporation.

\section{Core Sample Preparation}

The methods used to prepare test cores for porewater extraction varied depending on the rock type, the method used to seal the core, and the type of extraction test to be done (triaxial or one-dimensional compression). The objective of the sample preparation procedure was to produce a test specimen of the appropriate length while minimizing exposure of the core to evaporation and heating.

\section{Cutting Methods}

Two methods were used to cut the cores to the required length for testing: a hacksaw equipped with a tungsten-carbide impregnated blade, and a gas-cooled diamond saw. The hacksaw cutting procedure used was the same as described by Yang and others (1988). The core segment to be cut was unwrapped, placed in a simple jig, and cut to the desired length. Nonwelded tuff cores required 2 to 5 minutes per cut using this technique. Moderately or densely welded tuff cores could not be cut using the hacksaw; only nonwelded tuff cores were cut using this method.

The gas-cooled diamond saw used was a Raytech 46-cm (18-inch) water-cooled saw that was modified to use compressed air or nitrogen (or any bottled gas) as a coolant. A 3-mm orifice was mountec about $25 \mathrm{~mm}$ below the cutting deck to direct the gas coolant at the cutting surface of the blade. The gas served to flush cuttings from the blade surface and to cool the blade without blowing directly on the core during cutting. A delivery pressure of about $0.7 \mathrm{MPa}$ was adequate to prevent densely welded tuff cores from heating more than about $3^{\circ} \mathrm{C}$ during cutting (nonwelded tuff cores usually showed no heating during cutting). Nonwelded tuff cores were cut using about 1 minute per cut; welded tuff cores required between 3 and 15 minutes per cut depending on the degree of welding and the condition of the cutting surface of the blade. The diamond cutting surface was conditioned between samples by cutting abrasive sandstone using water as a coolant. (However, even with this sharpening between samples, blade life is significantly shortened by cutting with gas over the life that might be expected using water as a coolant.) An industrial-quality, segmented blade with a 3.2 -mm cutting width was the most efficient cutting blade.

Cutting cores using the gas-cooled diamond saw had several advantages over cutting using the hacksaw. The main advantage of cutting using the diamond saw was that the diamond saw could cut moderately and densely welded tuff cores that were too hard to be cut using the hacksaw. The diamond saw alsc cut faster and produced a much smoother cut surface than the hacksaw; the diamond saw allowed the core to remain sealed in aluminum foil and wax during cutting to minimize evaporation. Only nonwelded tuff cores prepared during the initial phases of experimentation were cut using the hacksaw method. The gas-cooled diamond saw was used to cut all the remaining test specimens.

The main objective in sample cutting was to produce test specimens that had smooth end surfaces that were perpendicular to the long axis of the core. The 
terms "smooth" and "perpendicular" as used here are only rough approximations of the test specimen requirements specified for compression testing by the American Society for Testing and Materials (1988c).

However, because precise measurements of rock properties were not the objective of this research, and becausc following ASTM sample prepuration requirements wr ald allow moisture in the test cores to evaporate, $\mathrm{m} \epsilon$. ing the ASTM requirements was not attempted.

After the cores were cut to the appropriate length, the test specimens were sealed in plastic film, aluminum foil, and beeswax and stored in a refrigerated locker until tested. Pore-water-extraction tests were done on most specimens within 24 hours of cutting. Specimens that were to be tested within about 4 hours of cutting were sealed in plastic film and two layers of reclosable (Ziploc) plastic bags and placed in refrigerated storage until tested. End pieces from cut cores were dried to a constant weight at 100 to $105^{\circ} \mathrm{C}$ to determine the moisture content of the pieces (American Society for Testing and Materials, 1988a). This moisture content was assigned to the test specimen. The moisture content of the cut ends also was occasionally checked by drying the compressed core and backcalculating the initial moisture content. Good agreement between moisture content values was obtained if the mass of the dried, cut ends was at least $100 \mathrm{~g}$.

\section{Variations in Procedure Due to Sealing}

The method used to seal the cores also affected the procedure used to prepare the cores for testing. Cores that were sealed in Lexan liner or split PVC pipe were removed from their tubes, wrapped in plastic film and cloth tape, and cut. Cores that were sealed in aluminum foil and beeswax were prepared for cutting by trimming off a 13-mm wide band of foil and wax at the location of the cut just prior to cutting. This minimized exposure of the entire core to evaporation. The rest of the core remained sealed during cutting. In all cases where two cuts were required, the cut face of the core was wrapped in plastic film to reduce evaporation during the second cut.

\section{Variations in Procedure Due to Test Method}

The type of pore-water-extraction test to be done also affected the sample preparation by controlling the length of core required. The triaxial compression cell used in this study can accommodate specimens ranging in length from about 98 to $113 \mathrm{~mm}$ using the standard, 102-mm long platens. (Shorter specimens can be tested using longer platens; a trial-and-error process would be necessary to determine the appropriate length range if longer platens were used.) The onedimensional compression cell can compress specimens as long as about $110 \mathrm{~mm}$ and has no minimum length limit. Cores were cut to lengths appropriate for the test method to be used.

\section{Water and Gas Sample Handling}

Pore-gas and pore-water samples were collected at different loading increments to evaluate the efficiency of pore-water extraction and any chemical changes in pore water from the loading technique. Water chemistry results will be reported separately; it is appropriate here, however, to discuss the samplecollection techniques. Pore-gas samples were collected in glass syringes and stored in the collection syringe for subsequent analysis of trace gas composition by gas chromatography. Analysis of carbon dioxide, methane, and sulfur hexafluoride by gas chromatography was done on a minimum volume of $2 \mathrm{~mL}$ as soon as possible after collection. Gas analyses were made to determine relative enrichment or depletion of these gases in comparison to atmospheric concentrations. (Sulfur hexafluoride was used as a gas tracer during coring of Yucca Mountain boreholes.)

Pore-water samples were collected in disposable, sterile, plastic syringes and were filtered through $0.45-\mu \mathrm{m}$ disposable filters before storage. Immediately after filtration, the $\mathrm{pH}$ and specific conductance of each water sample was measured using compact $\mathrm{pH}$ and specific conductance meters manufactured by Horiba, Inc.; the three to four drops of water required for each measurement were not recoverable. Replicate $\mathrm{pH}$ and specific conductance measurements were made when the water-sample volume (before filtration) was more than $3 \mathrm{~mL}$. After completing these measurements, the remaining water was stored in tightly-capped polyethylene bottles; the bottle caps were sealed using two wraps of plastic tape to further minimize leakage of water vapor during storage. Sample bottles were placed in refrigerated storage at $9^{\circ} \mathrm{C}$ until delivery to the contract laboratory for analysis of dissolved ionic chemistry. Sample handling, including filtration and $\mathrm{pH}$ and specific conductance measurements, normally used a total of $0.5 \mathrm{~mL}$ of the pore-water sample.

The type of analysis desired for the water extracted from an individual tuff core was considered during every extraction test. Unless water from two or more extraction lests was to be combined to form a composite sample, the extraction test was continued until sufficient water was obtained for analysis.

(Because composite water samples may introduce min- 
eralogical variability effects as another unknown, composite samples were avoided whenever possible.) The minimum water volume required for a sample is dependent on several factors: the type of analysis to be done, the laboratory making the analysis, and the measurement precision required for each analysis. The type of analysis to be done and the type of instrument used for the analysis affect the minimum water volume because each analysis technique and specific instrument has a minimum water volume requirement. Each laboratory also has its own unique equipment configuration and, therefore, its own minimum sample volume requirements. Finally, the required level of precision for each analysis adds another constraint on the minimum water-sample volume.

Based on all of the above considerations, the minimum water-sample volume (sent to the laboratory for a complete analysis) was $2.0 \mathrm{~mL}$. The target watersample volume (before filtration) was $3.0 \mathrm{~mL}$; the target volume included $0.5 \mathrm{~mL}$ for water-sample handling and $0.5 \mathrm{~mL}$ for contingencies.

\section{PORE-WATER EXTRACTION BY TRIAXIAL COMPRESSION}

\section{Design of Triaxial Pore-Water-Extraction System}

The objective of triaxial compression testing was to build on and improve the technique developed by Yang and others (1988). The triaxial compression cell design for pore-water extraction used during the initial phases of this study was the same as used previously by Yang and others (1988). A schematic diagram of this system is shown in figure 8 . The triaxial cell is made of a 4140-alloy steel body and end caps and a urethane membrane; the body and end caps were heat treated to a yield strength of $1100 \mathrm{MPa}$ and were nickel plated. Vented pore-pressure platens were used for transferring extracted water to external syringe collectors. Plastic syringes ( $10 \cdot \mathrm{cc}$ capacity) for water collection were connected to the platens by oversized stainless-steel hypodermic needles and compression fittings. The triaxial cell (not including syringes and needles) is commercially available from the Slope Indicator Company. This triaxial cell could accommodate core samples that were between 98 and $113 \mathrm{~mm}$ in length and $61 \mathrm{~mm}$ in diameter. (Samples less than $98 \mathrm{~mm}$ in length could be compressed, but would require $\mathrm{p}$ oportionately longer platens.)

This pore-water-extraction system has several strong points advantages: (1) pore water is collected from both ends of the core sample, which maximizes drainage efficiency; (2) quantities of extracted water can be measured during collection. which enables the calculation of pore-water-extraction rates; and (3) water samples can be collected at various applied stresses without disassembly of the cell.

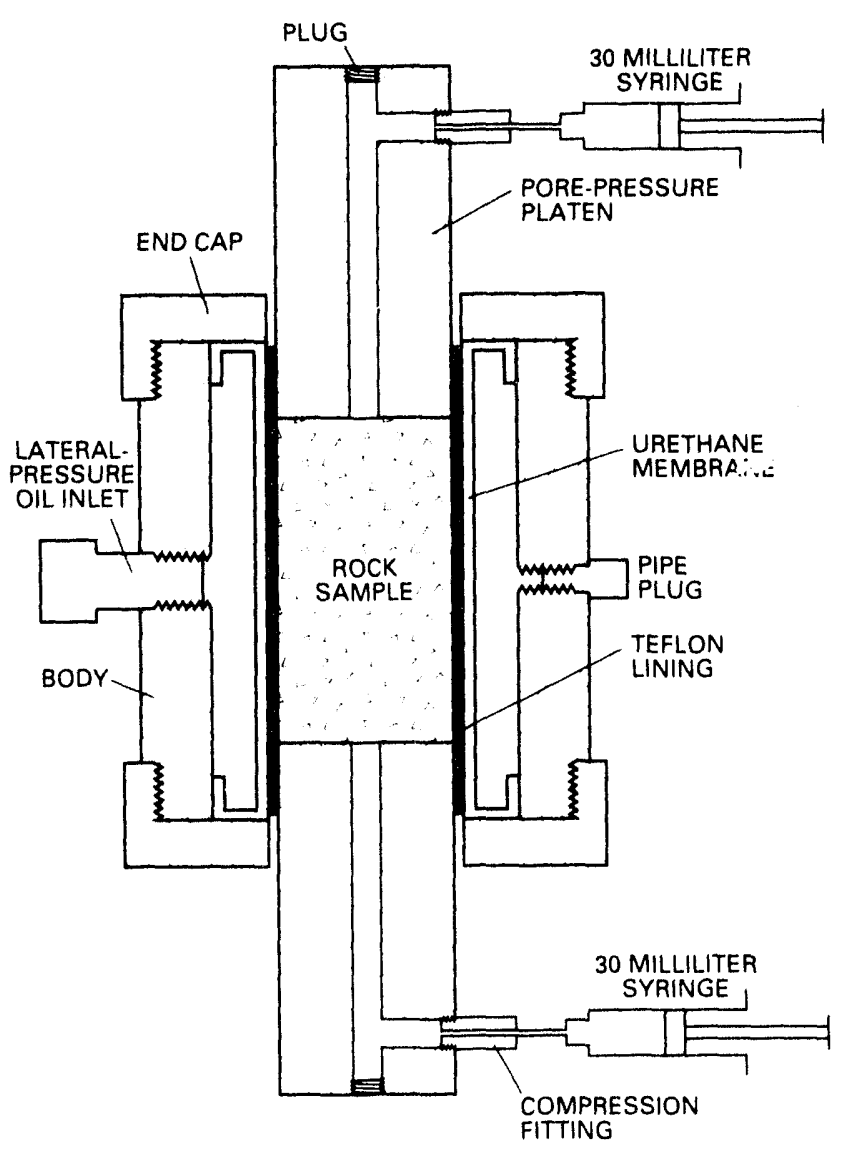

Figure 8. Triaxial cell used by Yang and others.

During the course of testing using this porewater-extraction system, several additional modifications were made to improve the operation of the system:

1. Single syringes were replaced with pairs of syringes. Using a pair of syringes at the exit port of each platen made changing syringes easier; a three-way stopcock was used to connect each pair of syringes. The original oversized hypodermic needle was replaced by a short length (about $5 \mathrm{~cm}$ ) of stainlesssteel tubing that was connected to the stopcock and syringes by Tygon tubing.

2. Disposable syringes and filters were used instead of washing and reusing syringes and filterpaper holders. Increasing the amount of disposable water-collection equipment reduced the risk of watersample contamination. New syringes also operated 
much more smoothly than washed, reused syringes; new syringes required much less pressure to push out the plungers because the plunger lubricant had not been washed off. Disposable filters eliminated opportunities for leakage and contamination created by using filterpaper holders.

3. Syringe size was reduced from $30 \mathrm{~mL}$ to $10 \mathrm{~mL}$. Smaller-capacity syringes increased the precision in water volume measurements from $0.5 \mathrm{~mL}$ to $0.1 \mathrm{~mL}$.

4. The sealing ability of the triaxial cell urethane membrane was improved by adding rubber inserts inside the seal flanges of the urethane membrane. Leakage of confining fluid occurred frequently when rubber inserts were not used; reducing leakage enhanced the general operation of the triaxial cell by improving its ability to maintain a constant confining pressure. These mechanical modifications to the triaxial pore-water-extraction system are illustrated in figure 9.

A major change also was made in the operating procedure of the triaxial pore-water-extraction system as described in Yang and others (1988). After the test core had been loaded to the maximum axial and confining stress, nitrogen gas was injected through the upper platen. If the core had been compressed enough to reach 100 percent saturation, the injection of nitrogen gas forced additional pore water out of the core and through the bottom platen. A brief description of the gas injection procedure is included in the following section; a more detailed discussion of pore-water displacement using gas injection is presented later in this report.

\section{Operation of Triaxial Pore-Water-Extraction System}

Operation of the triaxial compression cell requires a load frame capable of applying at least $580 \mathrm{kN}$ axial load and a hydraulic system capable of generating at least $69 \mathrm{MPa}$. During this study, a load frame that had a capacity of $4.4 \mathrm{MN}$ and a hydraulic system capable of supplying $138 \mathrm{MPa}$ were used for all triaxial compression testing. An overview of porewater extraction by triaxial compression follows to explain the general procedure.

A clean urethane membrane is inserted into the body of the triaxial cell. The end caps are screwed on and the space between the urethane membrane and the cell body is filled with hydraulic oil. A test core, jacketed in one wrap of Teflon is inserted within the urethane membrane. (Teflon is used as a chemically inert barrier between the sample and the urethane membrane to reduce the potential for chemical reactions between the expelled pore water and the urethane membrane.) Two pore-pressure platens are inserted into the urethane membrane and centered above and below the test core. A slight hydraulic pressure is applied to the confining fluid and the entire assembly is placed in the load frame. The compression fittings, stainless steel tubing, and syringes are attached for gas and water collection.

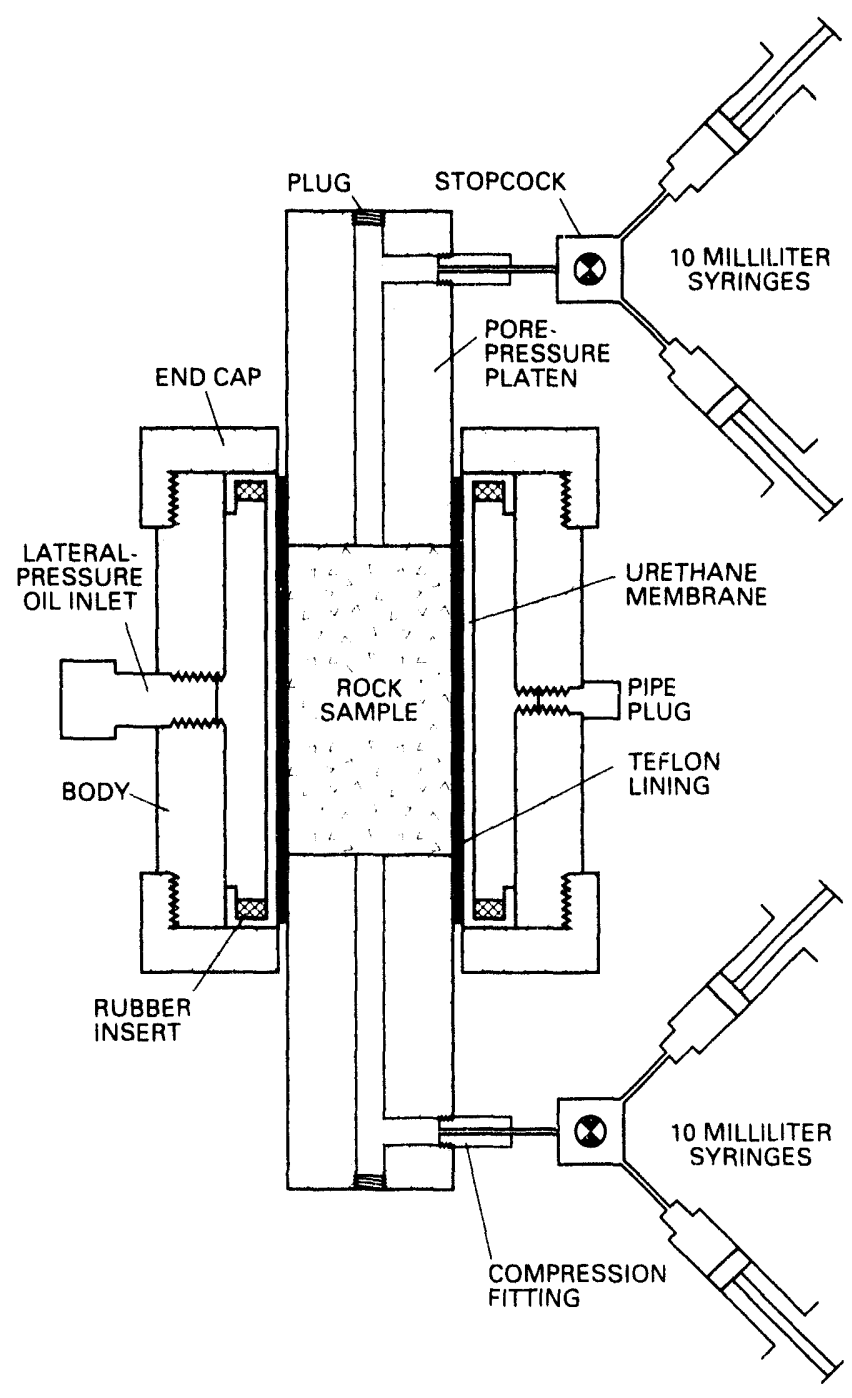

Figure 9. Modified triaxial cell used in this study.

The core is loaded hydrostatically (axial stress equal to confining stress) to $68 \mathrm{MPa}$, which is slightly less than the design pressure limit $(69 \mathrm{MPa})$ for the urethane membrane. The confining stress is held constant while the axial stress is increased in four steps to a maximum of $193 \mathrm{MPa}$; the load rate between steps is $69 \mathrm{kPa} / \mathrm{s}$. The four stress levels correspond to axial stresses of $76,117,152$, and $193 \mathrm{MPa}$; a loading history 
diagram that illustrates this loading pattern is shown in figure 10. The maximum axial stress was chosen conservatively to avoid the development of a shear failure plane in the sample that might, in turn, cause the rupture of the urethane membrane. (Handin and Hager, 1957) noted that most dry sedimentary rocks will fracture when the ratio of axial to confining stress reaches three to four.)

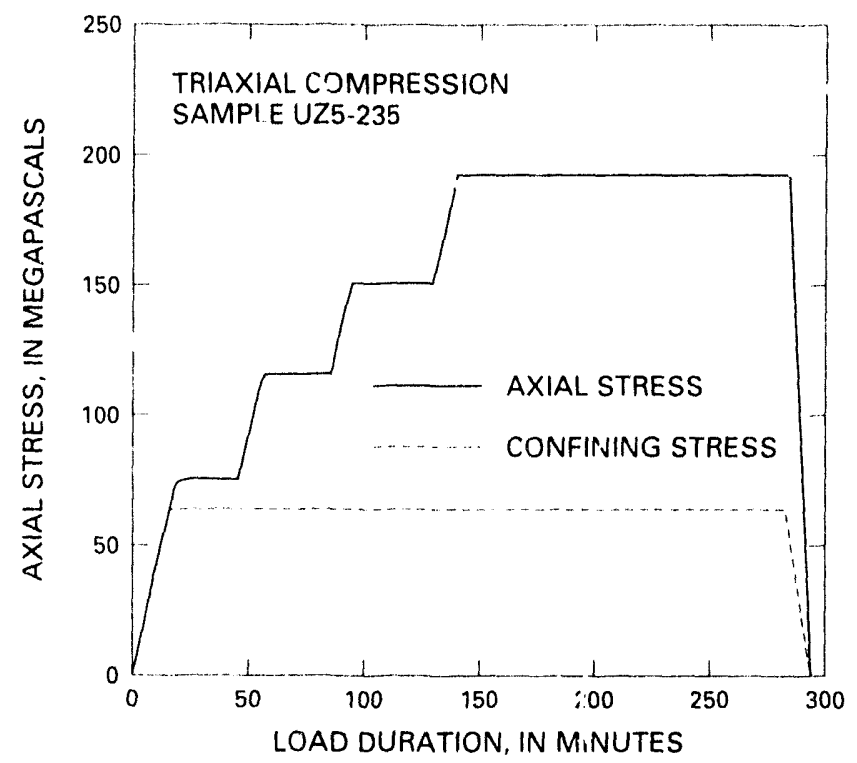

Figure 10. Loading history for triaxial compression.

The loading steps were chosen to evenly distribute several steps over the load range to allow porewater samples to be collected at different stress levels for chemical analyses and to allow time for maximum compaction of the sample. The loading rate is about the same as recommended for triaxial compression of nonwelded tuff for determination of strength properties (American Society for Testing and Materials, 1988b) and was selected to allow completion of the extraction test in 6 to 8 hours. The loading rate and the first three stress levels are also identical to those used by Yang and others (1988). When adequate volumes of gas $(\geq 2 \mathrm{~mL}$ ) or water ( $\geq 3 \mathrm{~mL}$ ) are collected, syringes are replaced for additional samples. Gas samples are stored; water samples are filtered, measured for $\mathrm{pH}$ and specific conductance, and stored. All samples are analyzed as soon as possible after collection.

At the maximum axial stress, after water expulsion (if any) has ceased and the core has stopped compacting, additional pore water may be extracted by injecting dry (> 99.999 percent pure) nitrogen gas into the pore space and forcing out pore water. Nitrogen pressure that ranged from 0.3 to $9.7 \mathrm{MPa}$ was applied through the upper platen from a nitrogen tank. Nitrogen injection was continued until sufficient water had been collected for analysis or the injection had continued for at least 1 hour with no water production.

When pore-water extraction is completed, the test core is unloaded. Axial stress is removed until the axial stress equals the confining stress; then, both axial and confining stresses are removed at the same rate until both are zero. The triaxial cell is then removed from the load frame, disassembled, and the components that contacted the core or the extracted water are washed, rinsed in deionized water, and thoroughly dried.

\section{Mechanical Data for Triaxial Compression}

Selected mechanical data collected from 17 pore-water-extraction tests using triaxial compression are summarized in table 1 . The data are divided into two sets according to the degree of welding of the samples. Supplemental mechanical data collected from triaxial compression tests are listed in table 2.

Previous work (Yang and nthers, 1988) indicated that the minimum initial moisture content for successful pore-water extraction from nonwelded tuff cores was 13 percent. Because nearly all the cores available for triaxial compression experimentation had moisture contents less than 13 percent, the initial moisture content of nine of the cores used for triaxial testing was artificially increased. Water was added to a prepared core by placing the core in a beaker of deionized water so that about half the core was immersed for a period ranging from 10 to 90 minutes; during the average immersion time of 40 minutes, the core was turned over several times to maximize the volume of water imbibed by the core. After immersion, the core was sealed in one layer of plastic film wrap and three layers of reclosable plastic bags and placed in refrigerated storage. The core remained in storage for an average of 48 hours to allow core moisture conditions to equilibrate before pore-water-extraction testing. These cores were too dry to produce water in their ambient states; increasing the initial water saturation of the cores allowed development of water extraction methods by providing test samples that were moist enough 'o yield water using triaxial compression. The initial moisture content of the set of nine cores was increased from 5-12 percent to 13-32 percent. This corresponds to increases in initial water saturation from 20-39 percent to 42-56 percent.

Leakage of the confining fluid from the triaxial cell was a common mechanical problem until the cell configuration was successfully modified (refer to "Design of Triaxial Pore-Water-Extraction System") 
Table 1. Mechanical data for triaxial compression

[Moisture content in percent of dry soil weight; pct, percent; MPa, megapascals; inj., injection; min. minutes; mL, milliliters. For all tests, confining stress ranged from 64 to $68 \mathrm{MPa}$

\begin{tabular}{|c|c|c|c|c|c|c|c|c|c|c|c|c|}
\hline \multirow[b]{2}{*}{$\begin{array}{l}\text { Sample } \\
\text { name }\end{array}$} & \multicolumn{3}{|c|}{ Initial conditions } & \multicolumn{3}{|c|}{ Test parameters } & \multicolumn{3}{|c|}{ Water recovery } & \multicolumn{3}{|c|}{ Final conditions } \\
\hline & $\begin{array}{c}\text { Initial } \\
\text { moisture } \\
\text { content } \\
(p c t)\end{array}$ & $\begin{array}{l}\text { Initial } \\
\text { satura- } \\
\text { tion' } \\
\text { (pct) }\end{array}$ & $\begin{array}{l}\text { Initial } \\
\text { porosity } \\
\text { (pct) }\end{array}$ & $\begin{array}{c}\text { Maximum } \\
\text { axial } \\
\text { stress } \\
\text { (MPa) }\end{array}$ & $\begin{array}{c}\text { Total } \\
\text { gas inj. } \\
\text { duration } \\
\text { (min) }\end{array}$ & $\begin{array}{l}\text { Total test } \\
\text { duration } \\
\text { (min) }\end{array}$ & $\begin{array}{l}\text { Volume } \\
\text { without } \\
\text { gas in]. } \\
(\mathrm{mL})\end{array}$ & $\begin{array}{l}\text { Volume } \\
\text { with } \\
\text { gas inj. } \\
\text { (mL) }\end{array}$ & $\begin{array}{l}\text { Total } \\
\text { volume } \\
\text { (mL) }\end{array}$ & $\begin{array}{l}\text { Final } \\
\text { porosity } \\
\text { (pct) }\end{array}$ & $\begin{array}{l}\text { Total } \\
\text { axial } \\
\text { strain } \\
\text { (pct) }\end{array}$ & $\begin{array}{c}\text { Extraction } \\
\text { success } \\
\text { (pct) }\end{array}$ \\
\hline \multicolumn{13}{|c|}{ Nonwelded tuff } \\
\hline UZ4-182 & ${ }^{5} 32.3$ & ${ }^{5} 56$ & 58 & 97 & 36 & 310 & 56 & 4 & 60 & 46 & 22 & 64 \\
\hline UZ4-190 4 & ${ }^{5} 24.1$ & ${ }^{5} 50$ & 54 & 152 & 50 & 149 & 47 & 0 & 47 & 34 & 30 & 59 \\
\hline$U Z 4-237^{4}$ & ${ }^{5} 16.3$ & ${ }^{5} 54$ & 42 & 152 & 87 & 399 & 6 & 15 & 21 & 28 & 19 & 32 \\
\hline$U Z 4-238^{4}$ & ${ }^{5} 14.3$ & $5_{47}$ & 42 & 117 & 70 & 240 & 13 & 15 & 28 & 30 & 17 & 49 \\
\hline$U Z 4-240^{4}$ & ${ }^{5} 17.5$ & ${ }^{5} 55$ & 43 & 76 & 40 & 364 & 5 & 11.5 & 16.5 & 38 & 8 & 23 \\
\hline$U Z 4-241^{4}$ & ${ }^{5} 16.5$ & $5_{53}$ & 43 & 117 & 49 & 343 & 12.5 & 11 & 23.5 & 32 & 16 & 36 \\
\hline$U Z 4-242^{4}$ & ${ }^{5} 12.6$ & $5_{42}$ & 42 & 165 & 70 & 365 & 4.5 & 13.5 & 18 & 24 & 23 & 35 \\
\hline UZ5-223 & ${ }^{5} 25.7$ & ${ }^{5} 53$ & 54 & 138 & 0 & ${ }^{6} 90$ & 42 & 0 & 42 & 39 & 24 & 50 \\
\hline$U Z 5-235^{4}$ & 6.8 & 16 & 51 & 193 & 17 & 292 & 0 & 0 & 0 & 23 & 37 & 0 \\
\hline UZ5-246 & 11.8 & 34 & 45 & 179 & 92 & 507 & 0 & 11 & 11 & 21 & 31 & 24 \\
\hline UZ5-269 & 11.0 & 24 & 53 & 179 & 68 & 288 & 0 & 6 & 6 & 29 & 33 & 16 \\
\hline UZ5-330 & 12.4 & 25 & 54 & 117 & 0 & ${ }^{6} 87$ & 0 & 0 & 0 & 42 & 21 & 0 \\
\hline UZ5-333 & 9.6 & 37 & 38 & 152 & 7 & ${ }^{6} 133$ & 0 & 0 & 0 & 26 & 17 & 0 \\
\hline UZS-334 & 21.0 & 58 & 47 & 152 & 0 & 146 & 18 & 0 & 18 & 29 & 25 & 23 \\
\hline \multirow[t]{2}{*}{ UZ13-354 } & ${ }^{5} 17.2$ & $5_{51}$ & 45 & 152 & 0 & 300 & 30 & 0 & 30 & 24 & 28 & 43 \\
\hline & \multicolumn{12}{|c|}{ Moderately welded tuff } \\
\hline UZN46-8 & 3.1 & 12 & 39 & 34 & 0 & ${ }^{7} 9$ & 0 & 0 & 0 & 39 & 0 & 0 \\
\hline UZN46-33 & 7.6 & 66 & 22 & 193 & 104 & 237 & 0 & 6 & 6 & 20 & 2 & 14 \\
\hline
\end{tabular}

${ }^{1}$ Initial saturation and porosity calculated from moisture content and test specimen dimensions and weight. (Note that nonwelded tuff samples often contain zeolite and clay mineials which can. in tum, affect the moisture content determined for a test specimen. Saturation and porosity values should be considered approximate.)

${ }^{2}$ Final porosity calculated from initial porosity and total axial strain.

${ }^{3}$ Extraction success calculated as the total volume of water extracted divided by the total volume of water in the test specimen.

${ }^{4}$ Test core originally sealed in split PVC pipe.

${ }^{5}$ Initial moisture content and saturation were arificially increased.

${ }^{6}$ Test ended prematurely due to confining fluid leakage.

${ }^{7}$ Test ended due to britle failure of specimen and rupture of cell membrane. 
Table 2. Supplemental mechanical data for triaxial compression

[mm. millimeters; $\mathrm{g} / \mathrm{cm}^{3}$. grams per cubic centimeter: $\mathrm{mL}$, milliliters; pct, percent; --, no data available]

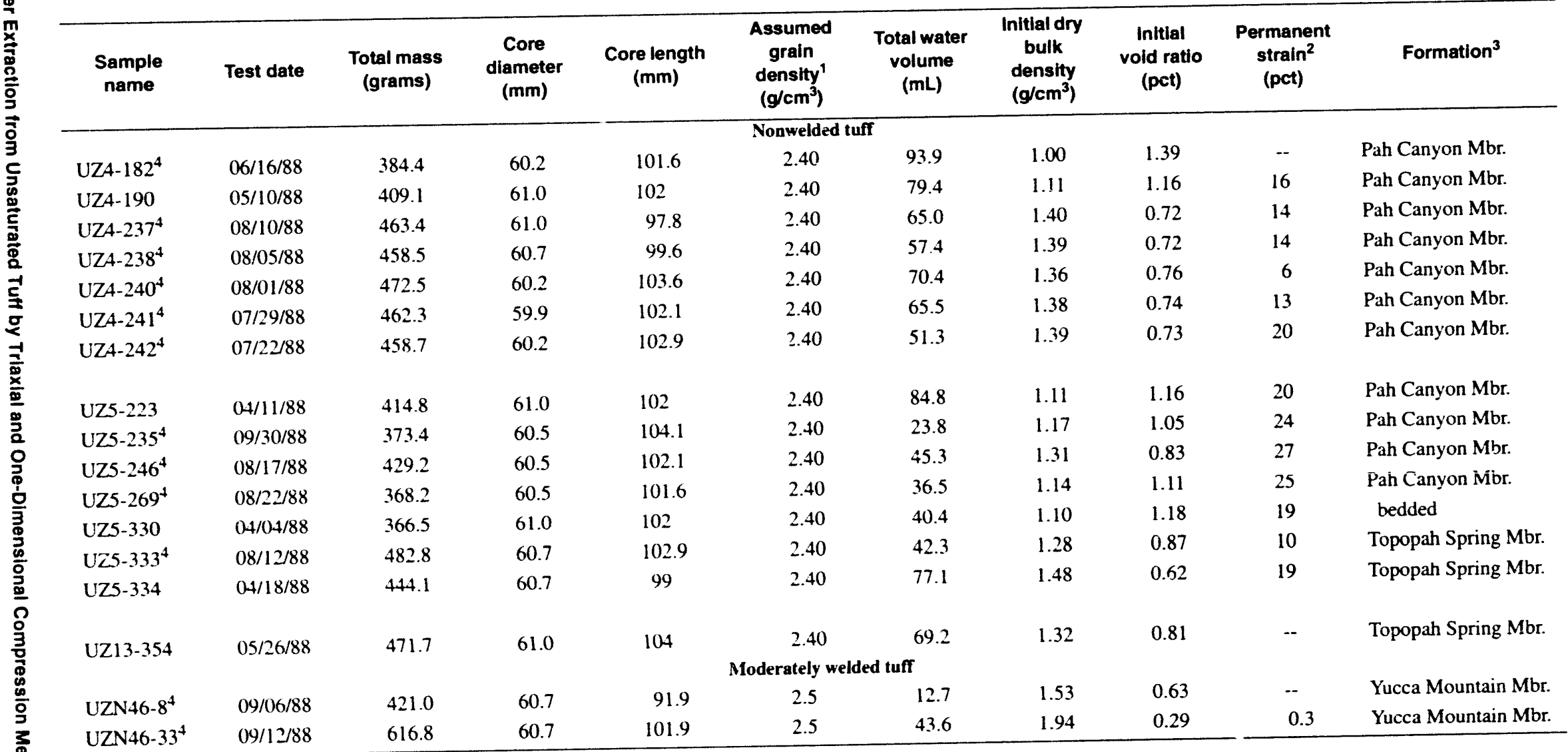

'Sources for grain density data: Price, 1983: Scott and others, 1983: Anderson, 1984: Rush and others. 1984.

Permanent strin is based on the sample length after the completion of a test (while subject to an axial load of about 9 kilonewtons).

Yucca Mountain Member. Pah Canyon Member, and Topopah Spring Member are subdivisions of the Paintbrush Tuff.

Sceres

${ }^{4}$ Core temperature monitored during compression. 
after the completion of 15 compression tests. Although 13 of the 17 triaxial compression tests had some leakage of confining fluid, only four of the tests had enough leakage to cause a premature end to the test. The water extraction data from these four tests (UZ5-223, UZ5-330, UZ5-333, and UZN46-8) are eliminated from the following discussion and graphs of the results of the triaxial compression testing.

Triaxial compression of nonwelded tuff cores resulted in porosity reductions of 12 to 55 percent with an average reduction of 37 percent. (Porosity reduction was calculated as the change in porosity divided by the initial porosity.) Total axial strains for nonwelded tuff tests ranged from 8 to 37 percent with an average value of 24 percent. (Note that the porosity reduction and total axial strain values are affected by the maximum applied axial stress for each test; because a range of axial stresses was used in triaxial compression testing, the stated ranges and average values of porosity reduction and total axial strain should be coupled with the range of applied axial stress when comparing these data to other compression test data.) The values of total axial strain agree closely with data acquired by triaxial compression of nonwelded tuff (using similar applied axial stresses) reported by Yang and others (1988).

The calculation of total axial strain assumes that lateral strain is zero. Although three of the tested cores did show visible barreling after testing, the majority of the cores had the same diameter after testing as before testing (within about $\pm 1 \mathrm{~mm}$ ). However, because lateral deformation was not measured during the triaxial tests, calculations that rely on the core volume at maximum compression (total axial strain and final porosity) should be considered approximate.

A representative axial stress-axial strain curve for a nonwelded tuff core tested using triaxial compression is illustrated in figure 11.

The relation between the initial moisture content of a test core and the volume of pore water extracted from the core without using gas injection is illustrated in figure 12. Note that the curves presented on this graph and similar graphs that follow were determined using least squares regression. The proportion of the variation explained by the regression, $\mathrm{R}^{2}$, was determined as described by Draper and Smith (1966). The minimum initial moisture content for successful porewater extraction without using gas injection was about 13 percent and the initial sc. 'Iration was 42 percent. The minimum initial moisture content for successful pore-water extraction is based - 1 experimental trials and not on the extrapolation of the regression line indicated on figure 12. This minimum value and the data trend indicate close agreement between this data set and data reported by Yang and others (1988) using the same extraction method on similar nonwelded tuff cores.

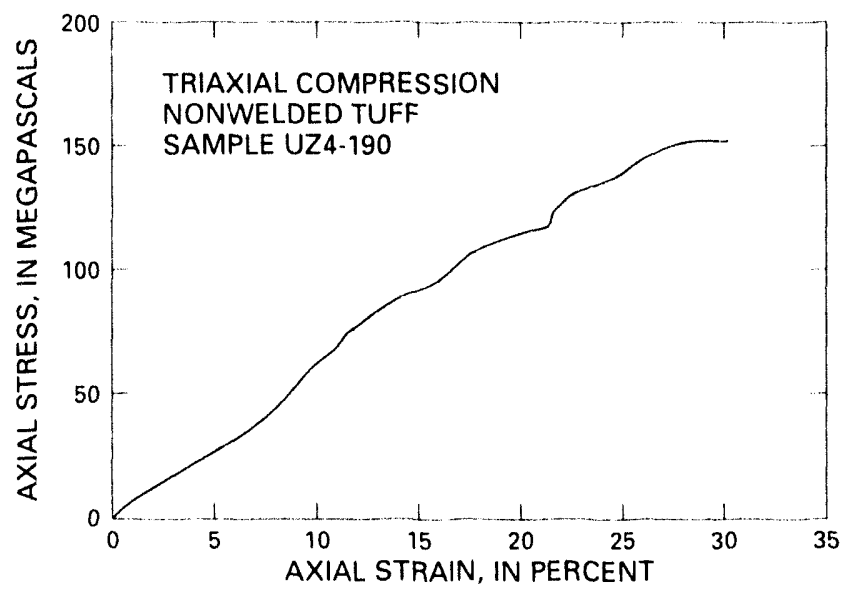

Figure 11. Relation between axial stress and axial strain for triaxial compression of a nonwelded tuff sample UZ4-190.

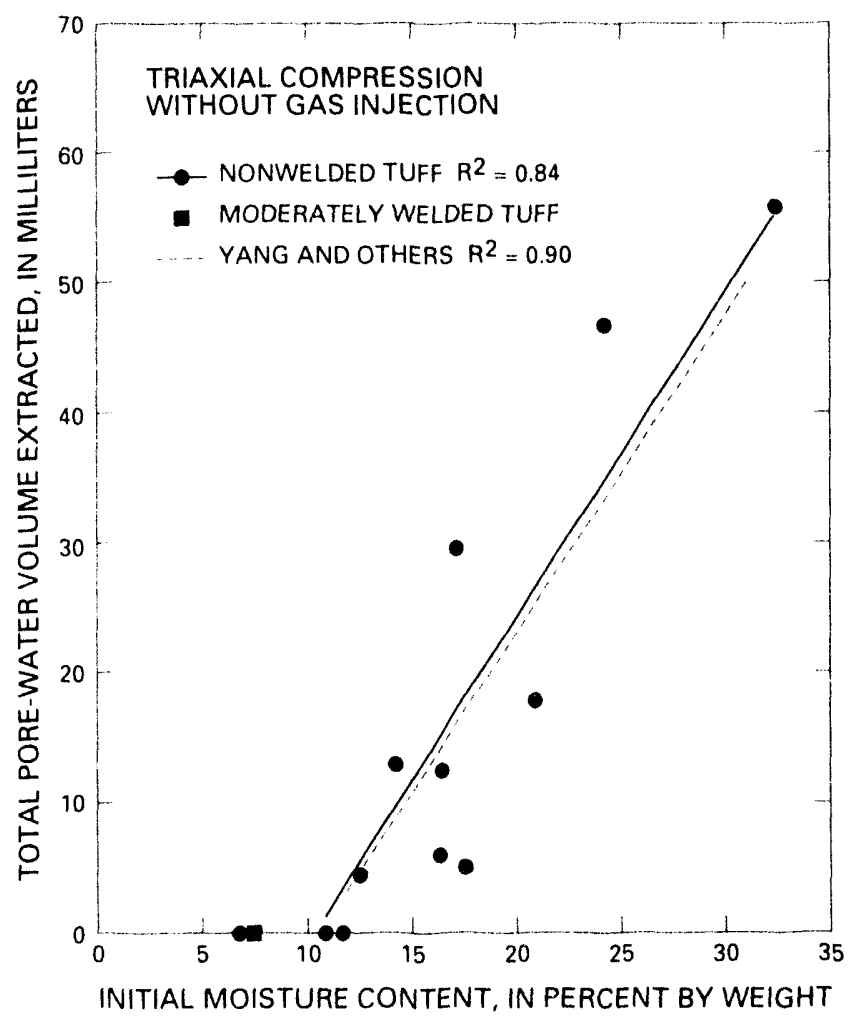

Figure 12. Relation between initial moisture content and volume of pore water extracted from cores using triaxial compression without gas injection. Data from this study are compared to data reported by Yang and others (1988).

As mentioned in the section "Operation of Triaxial Pore-Water-Extraction System," injection of an 
inert gas while the core is held at the maximum axial stress can be used to extract additional pore water. This improvement to the pore-water extraction process is illustrated in figure 13. Of the ten compression tests that used gas injection, nine produced additional water. The volume of water produced by gas injection ranged from 4 to $15 \mathrm{~mL}$, and represented 7 to 100 percent of the total volume of pore water recovered. Using gas injection reduced the minimum initial moisture content for successful pore water extraction by triaxial compression from 13 percent to about 11 percent and reduced initial saturation from 42 percent to 24 percent. Additional details concerning gas injection are included in the section titled "Additional Data for PoreWater Extraction Using Gas Injection."

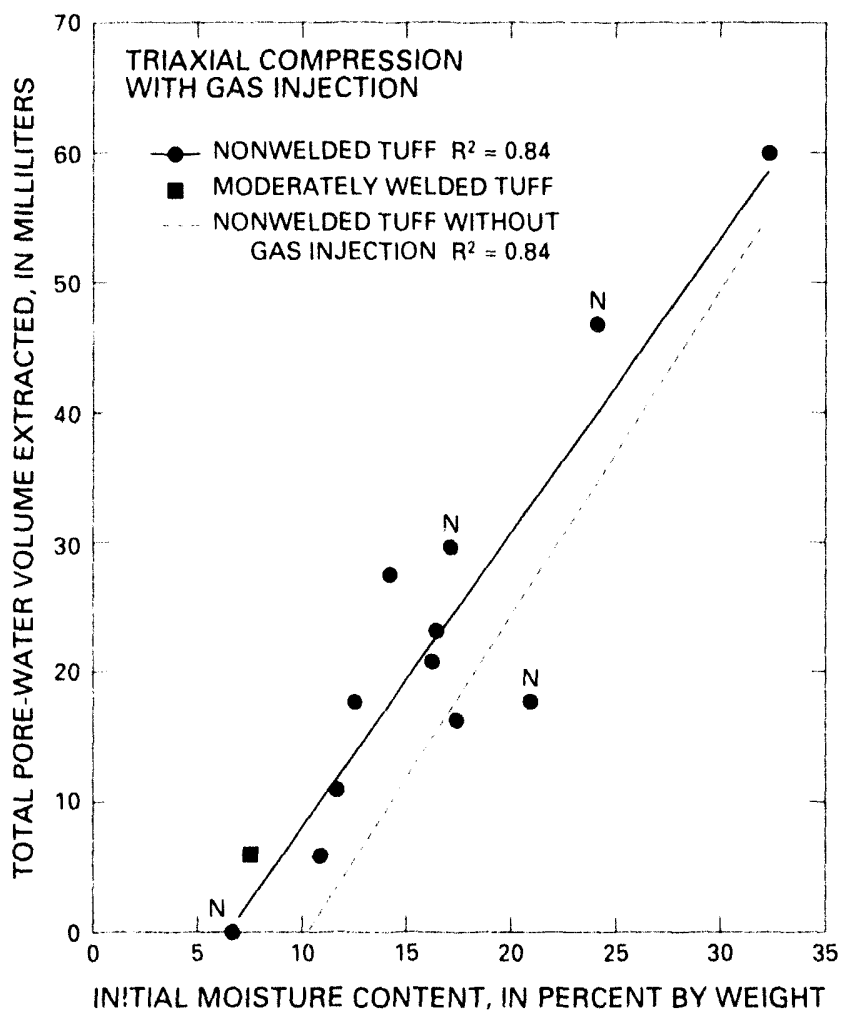

Figure 13. Relation between initial moisture content and volume of pore water extracted from cores using triaxial compression with gas injection. Comparison of volume extracted without using gas injection to volume extracted using gas injection. $(N)$ indicates no additional water recovered using gas injection.

Pore-water extraction by triaxial compression using gas injection resulted in values of extraction success that ranged from 16 to 64 percent, and the average value was 37 percent (including only tests that produced water). Extraction success was calculated as the total volume of pore water extracted from the test core divided by the total volume of water initially present in the core. The degree of extraction success increases as the initial moisture content of the test core increases (fig. 14). Because only a limited amount of compression is available, cores that have larger initial moisture contents produce more water by triaxial compression than cores that have smaller initial moisture contents.

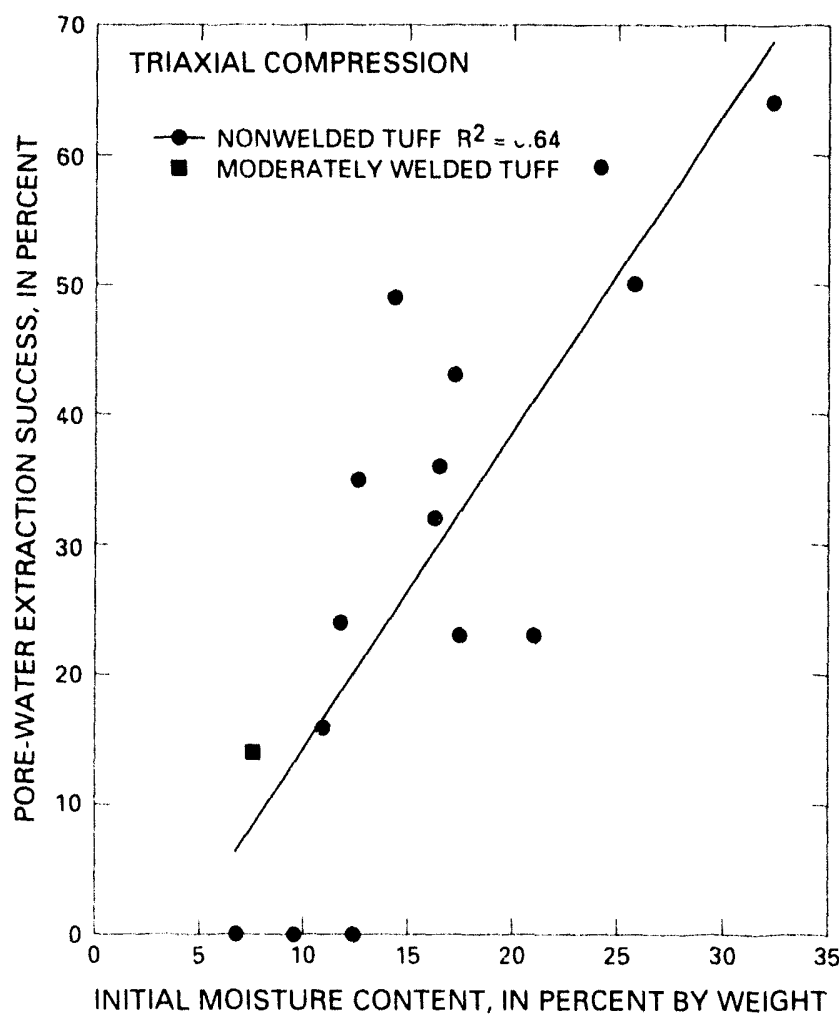

Figure 14. Relation between initial moisture content and pore-water extraction success for cores tested using triaxial compression.

Because most water-rock interactions are enhanced at increased temperatures (Stumm and Morgan, 1981), the temperature of the test core during compression was measured during 12 of the 17 triaxial tests. The core temperature was measured using a 30 -gauge type $K$ thermocouple that was threaded from the base of the core out through the water collection system. No temperature changes (except the initial warming of the test core from refrigerated conditions to room temperature) were noted during any of these tests. Two tests (UZ4-238 and UZ4-237) were done at faster loading rates ( 138 and $207 \mathrm{kPa} / \mathrm{s}$, respectively) to determine if the core temperature increased during rapid loading; neither test measured any temperature change. The core temperature during compression was not monitored on a routine basis because installation of the thermocouple significantly lengthened the test set-

16 Pore-Water Extraction from Unsaturated Tuff by Triaxial and One-Dimensional Compression Methods, Nevada Test Slte, Nevada 
up time and increased the risk of pore-water leakage. The 12 measurements made were believed to be sufficient to demonstrate that the temperature of a core does not increase during triaxial compression under the loading conditions used during this study.

Two triaxial compression tests (UZN46-8 and UZN46-33) were done on cores of moderately welded tuff. The test of sample UZN46-8 ended after only 9 minutes due to the brittle failure of the core and the subsequent rupture of the triaxial urethane membrane. The test of UZN46-33 did produce water after gas injection at a maximum axial stress of $193 \mathrm{MPa}$. However, the densely welded tuffs that compose most of Yucca Mountain have even smaller porosities and initial moisture contents (Montazer and Wilson, 1984) than these two moderately welded tuff samples tested using triaxial compression. Based on the results of triaxial compression and recognizing the need for a compression method that would be successful in extracting pore water from densely welded tuff cores, the onedimensional compression pore-water-extraction system was designed.

\section{PORE-WATER EXTRACTION BY ONE DIMENSIONAL COMPRESSION}

\section{Design of One-Dimensional Pore-Water- Extraction System}

A one-dimensional pore-water-extraction system was designed and fabricated especially for this study. This design was based on compression cells used in concrete research (Barneyback and Diamond, 1981). The primary design objectives were for a system that: (1) avoided the inherent difficulties of the triaxial system, such as membrane leakage; (2) was simple to operate; and (3) would operate efficiently over a large range of stresses so that pore fluids could be extracted from samples of both welded and nonwelded tuffs.

The one-dimensional compression system is shown schematically in figure 15 . The major components, made of 4340-alloy steel, are the corpus ring, base platen, piston, and piston guide; these components were heat treated to a yield strength of $1030 \mathrm{MPa}$. The sample sleeve and drainage plates are formed from Model K500 nickel alloy; these parts were agehardened to a yield strength of $690 \mathrm{MPa}$. The core is wrapped in a Teflon sheet and confined in the sample sleeve. The drainage plates have holes for pore-water drainage and are connected by nylon tubing to syringes for gas and water collection. The sample chamber is sealed by use of O-rings and a Teflon washer between the upper drainage plate and the piston. This closed system prevents contact between expelled pore water and the atmosphere. The one-dimensional compression cell has a maximum compressive ste ess rating of $552 \mathrm{MPa}$. This maximum rating is based on the yield strength of the steel used in the cell and on the thickness of the corpus ring.

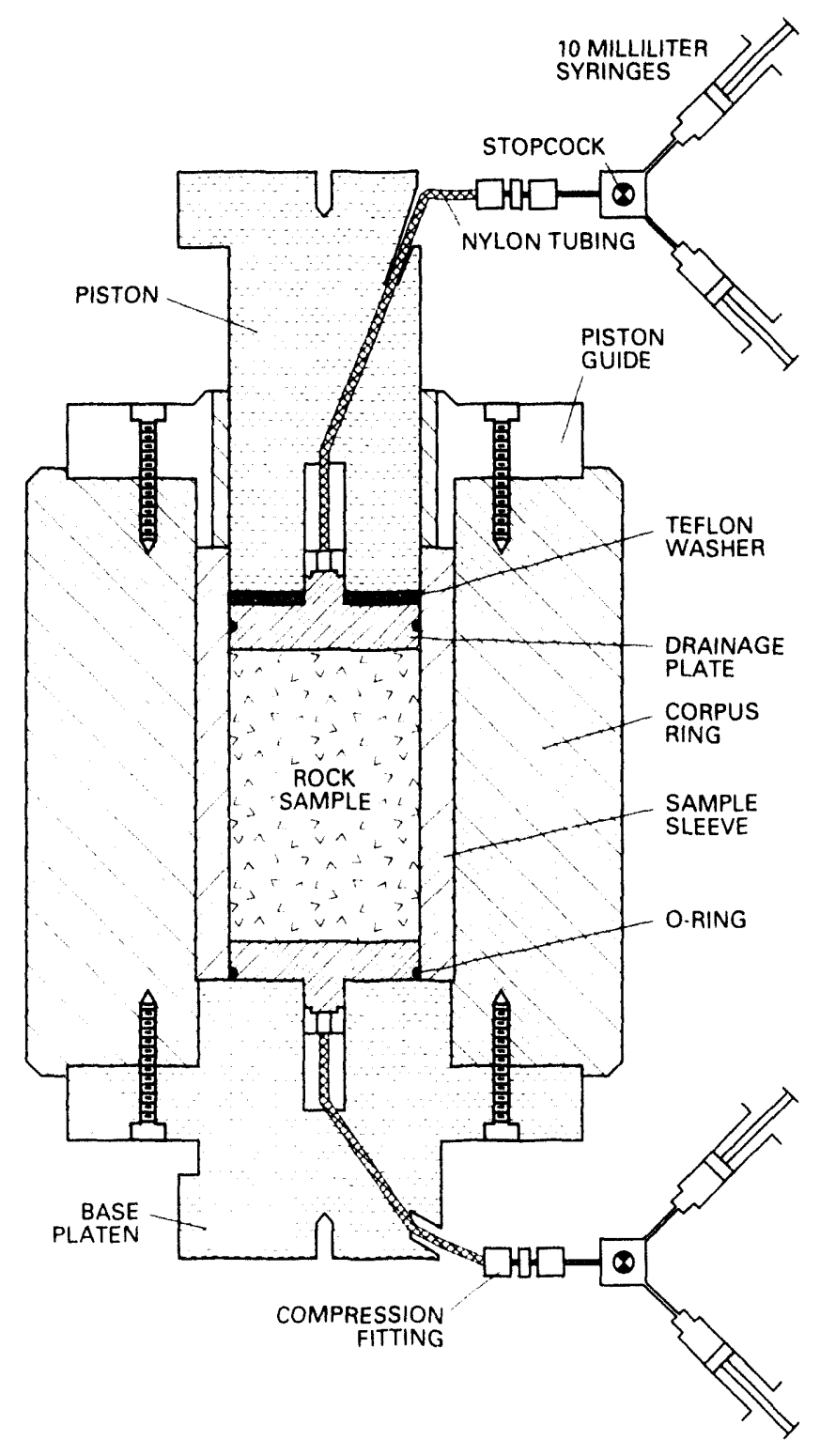

Figure 15. One-dimensional compression cell used in this study.

The one-dimensional compression cell can accommodate cores that are $61 \mathrm{~mm}$ in diameter and as long as $110 \mathrm{~mm}$. Core samples shorter than about $55 \mathrm{~mm}$ can be compressed by inserting steel spacers beneath the base drainage plate and effectively increasing the specimen length. The practical minimum spec- 
imen length is controlled by the amount of water in the test sample; the specimen must be of sufficient size to produce an adequate volume of water for analysis.

Two different types of drainage plates were used during one-dimensional compression testing: "grooved" and "smooth". Diagrams of the two types of drainage plates are presented in figure 16. The "grooved" drainage plates have the same pattern of grooves in the face that contacts the core as the platens used in the triaxial compression cell. Extracted water collects in the grooves and is directed to a central port that allows the water to pass to the rear of the plate. "Smouth" drainage plates have a circumferential drainage channe! that leads to two ports that, in turn, transmit the collected water from the edge of the plates through the inside to a central exit point at the rear of the plates. Compression fittings connect the rear of either style drainage plate to the nylon tubing that transmits expelled water out of the one-dimensional compression cell. During one-dimensional compression testing, grooved drainage plates were used unless otherwise noted. The smooth drainage plates tended to clog if the Teflon wrap on the specimen slipped by any appreciable amount.

\section{Operation of One-Dimensional Pore-Water- Extraction System}

A load frame capable of applying at least $1.7 \mathrm{MN}$ is necessary to generate the $552 \mathrm{MPa}$ maximum axial stress. Two load frames were used for one-dimensional compression testing in this study. A load frame that had a capacity of $1.3 \mathrm{MN}$ was used during the initial testing of the one-dimensional compression cell, including samples: UZ4-115, UZ4-338, UZ5-217, UZ5-230, and UZ5-327. Initial testing indicated that a load frame capable of generating the maximum $552 \mathrm{MPa}$ axial stress would be needed to maximize pore-water recovery. Therefore, all the remaining onedimensional compression tests were done using a load frame that had a capacity of $2.7 \mathrm{MN}$. An overview of pore-water extraction by one-dimensional compression follows to explain the general procedure.

The initial assembly of the one-dimensional compression cell begins with the preparation of the drainage pathways. Nylon tubing and compression fittings are attached to each drainage plate. The base drainage plate and base platen are then connected to the corpus ring. The test core is jacketed in one to two wraps of Teflon and is inserted into the cell. Teflon is used as a chemically inert barrier between the sample and the metal sample sleeve to reduce the potential for chemical reactions between the expelled pore water and the sample sleeve. The Teflon wrap allows the sample to compress without adhering to the sample sleeve and facilitates extrusion of the sample after a one-dimensional compression test. The top drainage plate, 3-mm thick Teflon seal washer, piston guide, and piston are then inserted into the top of the cell. The exterior compression fittings are connected to the nylon tubing, and the stainless-steel tubing and syringes are attached for gas and water collection.
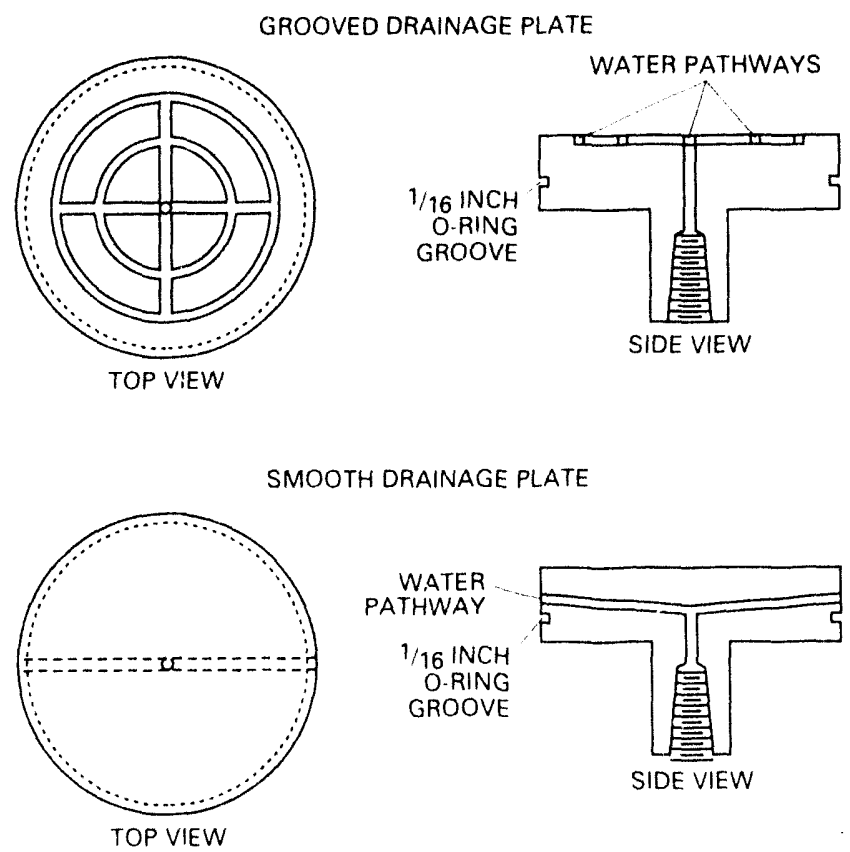

Figure 16. Drainage plates used in one-dimensional compression cell.

Before the core is loaded to the first stress level, a seating load of about 7 to $9 \mathrm{kN}$ is applied to the piston to ensure good metal-to-metal contacts between bearing components of the cell. The core is then loaded to the first stress level of $69 \mathrm{MPa}$ at a rate of $69 \mathrm{kPa} / \mathrm{s}$. Loading continues in seven increments of $69 \mathrm{MPa}$ (at the same loading rate) until the final stress level of $552 \mathrm{MPa}$ is reached; a loading history diagram which illustrates this loading pattern is shown in figure 17. The sequence of load steps was chosen to evenly distribute a number of steps over the entire load range, and to make the magnitude of the individual steps approximately equal to the size of the steps used in triaxial compression testing. The loading rate, which is the same as used during triaxial compression testing, was selected for the same reasons discussed for triaxial compression, and to maintain direct comparability with triaxial compression. Water and gas samples are taken when adequate volumes of gas $(\geq 2 \mathrm{~mL})$ or water 
$(\geq 3 \mathrm{~mL})$ are collected in the syringes. Gas samples are stored; water samples are filtered, measured for $\mathrm{pH}$ and specific conductance, and stored. All samples are analyzed as soon as possible after collection.

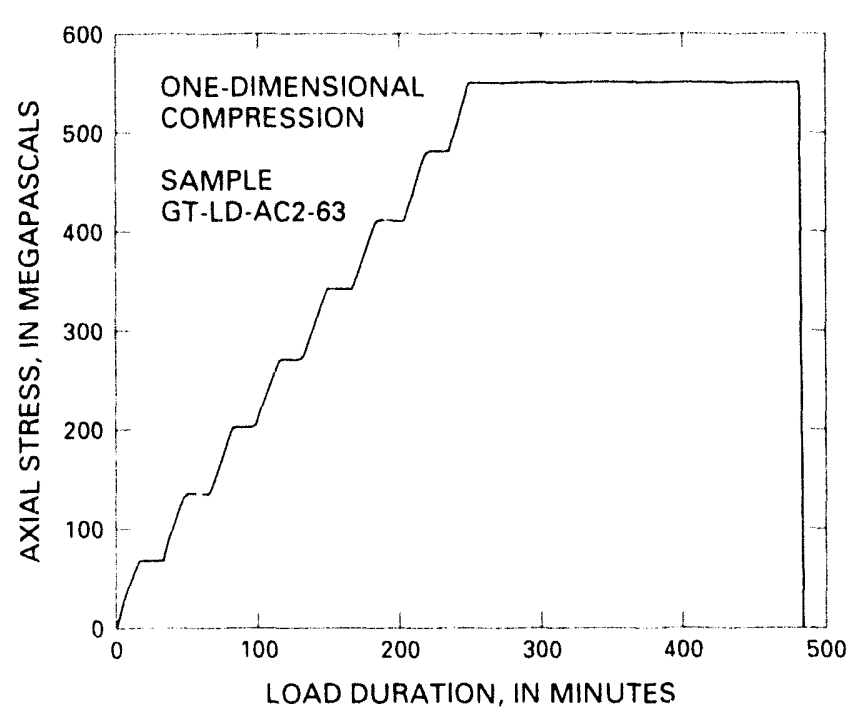

Figure 17. Loading history for one-dimensional compression of sample GT-LD-AC2-63.

At the maximum axial stress, after water expulsion (if any) has ceased and the core has stopped compacting, additional pore water may be extracted by injecting dry nitrogen ( $>99.999$ percent pure) gas into the pore space and forcing out pore water in the same manner as described for triaxial compression. Nitrogen pressure that ranged from 1.4 to $10.3 \mathrm{MPa}$ was applied through the piston from a nitrogen tank. Additional data and observations concerning gas injection are included in the section entitled "Additional Data for Pore-Water Extraction Using Gas Injection."

When pore-water extraction is completed, the test core is unloaded. Due to the large stresses used during one-dimensional compression, the test core is firmly seated in the sample sleeve and must be pressed out using the load frame. A steel cylinder that is slightly smaller in diameter than the core is used in conjunction with a support ring to press out the test core. After the core has been removed, the remaining components and fittings may be disassembled. Used syringes and nylon tubing are discarded; all components that contacted the core or the extracted water are washed, rinsed in deionized water, and thoroughly dried.

\section{Mechanical Data for One-Dimensional Compression}

Selected mechanical data collected from 32 pore-water-extraction tests using one-dimensional compression are summarized in table 3 . The data are divided into two sets according to the degree of welding of the samples. Supplemental mechanical data for one-dimensional compression tests are listed in table 4.

One-dimensional compression is an effective means of decreasing core porosity. Porosity decreases of 36 to 79 percent that have an average decrease of 63 percent were measured from nonwelded tuff tests. (Porosity reduction was calculated as the change in porosity divided by the initial porosity.) Densely welded tuff core porosity decreases ranged from 25 to 46 percent, and the average reduction was 37 percent. Total axial strains for nonwelded tuff tests ranged from 30 to 49 percent, and the average was 37 percent; densely welded tuff test strains varied from 6 to 13 percent, and the average was 9 percent. A representative axial stress-axial strain curve for a nonwelded tuff core tested using one-dimensional compression is illustrated in figure 18. A similar curve for one-dimensional compression of a densely welded tuff core is presented in figure 19. The short segments of the curves that indicate increasing axial strain at a constant axial stress represent creep as the core is held at various levels of axial stress.

Cores that have a larger initial moisture content produce more water than cores that have a smaller initial moisture content. The data for tests of nonwelded tuff cores (fig. 20) indicate this relation. The data for tests of densely welded tuff cores (fig. 20 and enlarged on fig. 21) indicate a similar, but less well defined relation between initial moisture content and total volume of pore water extracted. Excluding gas injection, the minimum initial moisture content for successful porewater extraction from nonwelded tuff cores was 7.6 percent and the initial saturation was 18 percent; the minimum initial moisture content for densely welded tuff cores was 7.7 percent and the minimum initial saturation was 74 percent. Injection of nitrogen gas while a core was compressed at the maximum axial stress did not produce additional pore water from nonwelded tuff cores. Gas injection produced all the water recovered from most of the densely welded tuff cores; gas injection reduced the minimum initial moisture content for successful pore-water extraction from densely welded tuff cores from 7.7 to 6.5 percent. Additional details concerning gas injection are included in the next section.

The one-dimensional compression process resulted in values of extraction success that ranged 
Table 3. Mechanical data for one-dimensional compression

[Moisture content in percent by weight; pct, percent; MPa, megapascals; inj., injection; min, minutes; mL. milliliters; tr, trace]

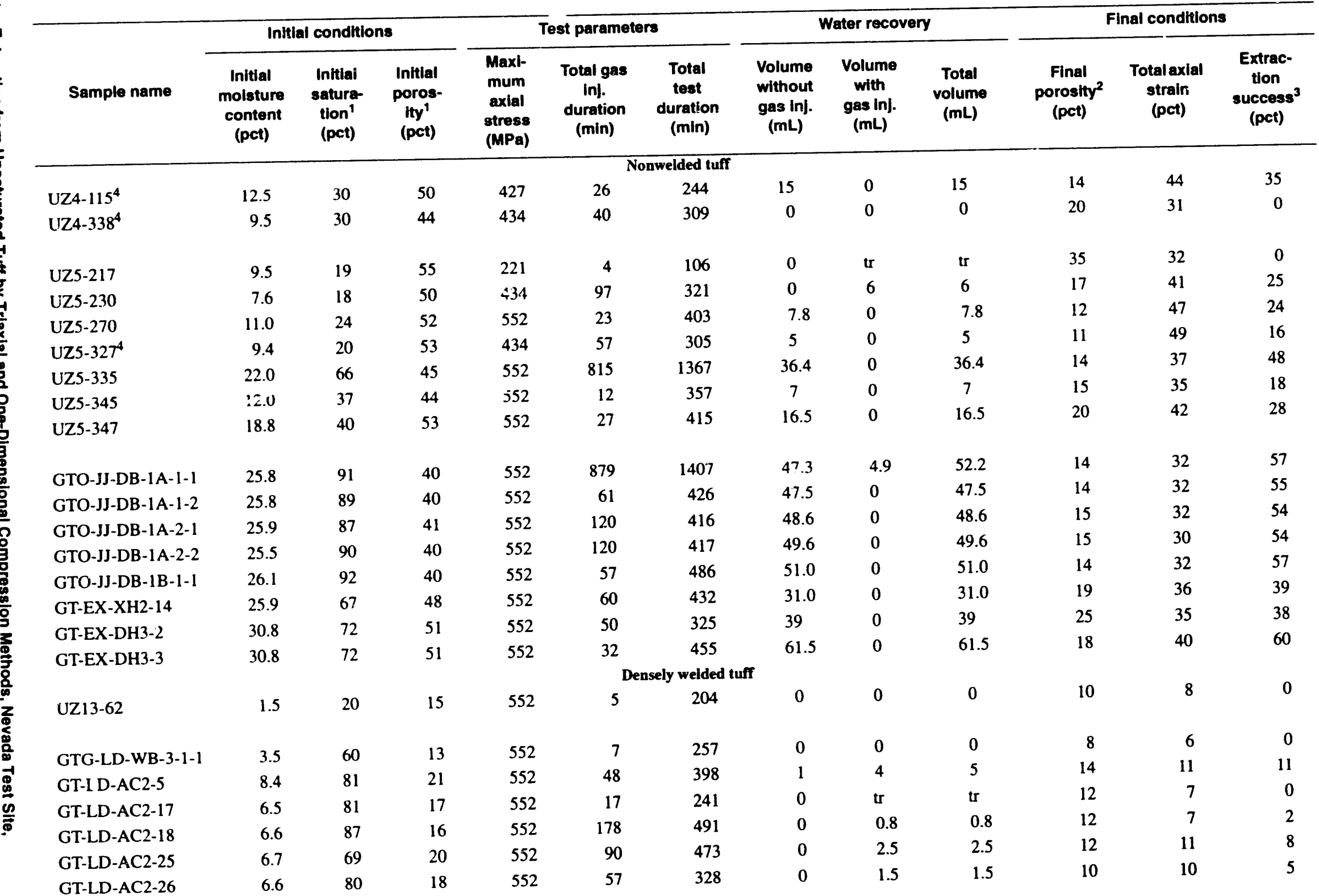


Table 3. Mechanical data for one-dimensional compression --Continued

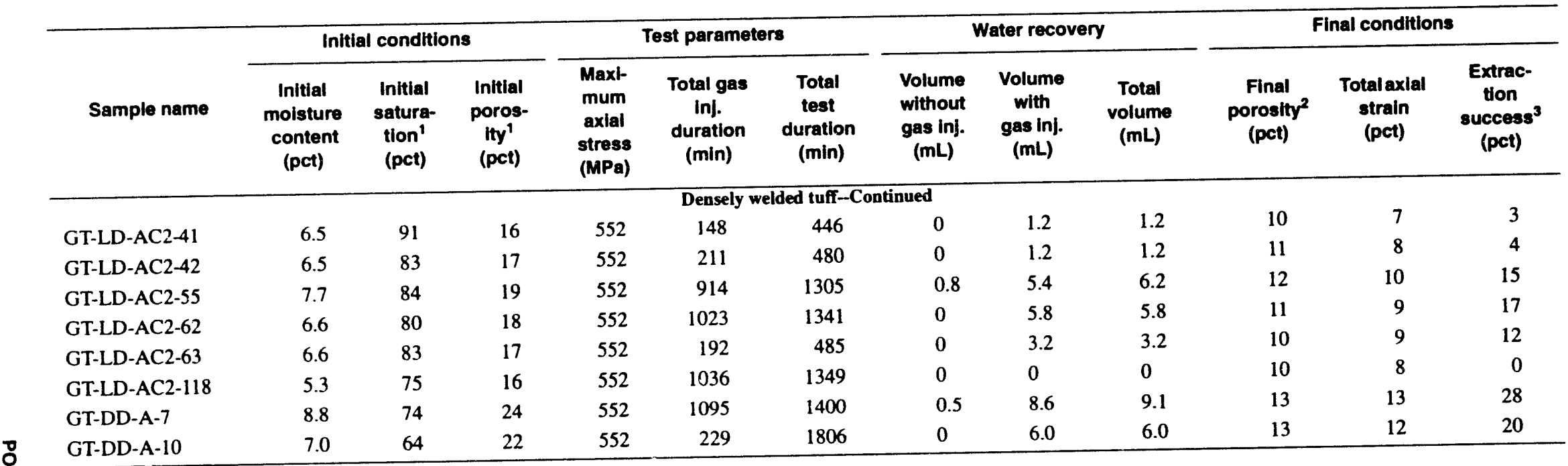

(Note that nonwelded tuff samples often contain zeolite and clay minerals which can. porosity calculated from moisture content and test specimen dimensions and weight. (Note that nonwelded in turn, affect the moisture content determined for a test specia axial strain.

${ }^{2}$ Final porosity calculated from initial porosity and total axial strain.

${ }^{4}$ Test core originally sealed in split PVC pipe. 
Table 4. Supplemental mechanical data for one-dimensional compression

[mm, millimeters; $\mathrm{g} / \mathrm{cm}^{3}$, grams per cubic centimeter; $\mathrm{mL}$, milliliters; pct, percent; --, no data available]

\begin{tabular}{|c|c|c|c|c|c|c|c|c|c|c|}
\hline Sample name & Test date & $\begin{array}{c}\text { Total } \\
\text { mass } \\
\text { (grams) }\end{array}$ & $\begin{array}{c}\text { Core } \\
\text { diameter } \\
(\mathbf{m m})\end{array}$ & $\begin{array}{l}\text { Core } \\
\text { length } \\
(\mathrm{mm})\end{array}$ & $\begin{array}{l}\text { Assumed } \\
\text { grain } \\
\text { density } \\
\left(\mathrm{g} / \mathrm{cm}^{3}\right) \\
\end{array}$ & $\begin{array}{c}\text { Total } \\
\text { water } \\
\text { volume } \\
\text { (mL) }\end{array}$ & $\begin{array}{c}\text { Initial dry } \\
\text { bulk } \\
\text { density } \\
\left(\mathrm{g} / \mathrm{cm}^{3}\right)\end{array}$ & $\begin{array}{c}\text { Initial } \\
\text { void ratio } \\
\text { (pct) }\end{array}$ & $\begin{array}{l}\text { Permanent } \\
\text { strain }^{2} \\
\text { (pct) }\end{array}$ & Formation ${ }^{3}$ \\
\hline \multicolumn{11}{|c|}{ Nonwelded tuff } \\
\hline UZ4-11 $5^{4}$ & $10 / 12 / 88$ & 385.2 & 60.5 & 99.8 & 2.40 & 42.8 & 1.20 & 1.01 & 39 & $\begin{array}{l}\text { Yucca Mountain Member } \\
\text { bedded }\end{array}$ \\
\hline$U Z 4-338^{4}$ & $10 / 31 / 88$ & 446.0 & 60.5 & 104.6 & 2.40 & 38.7 & 1.36 & 0.77 & 25 & \\
\hline UZ5-217 & $10 / 07 / 88$ & 343.8 & 60.5 & 100.3 & 2.40 & 29.8 & 1.09 & 1.20 & 28 & Pah Canyon Member \\
\hline$U Z 5-230^{4}$ & $11 / 04 / 88$ & 337.1 & 60.7 & 90.9 & 2.40 & 23.8 & 1.19 & 1.02 & 35 & Pah Canyon Member \\
\hline UZ5-270 & $08 / 04 / 89$ & 326.7 & 60.5 & 89.2 & 2.40 & 32.4 & 1.15 & 1.09 & 40 & $\begin{array}{l}\text { Pah Canyon Member } \\
\text { bedded }\end{array}$ \\
\hline$U Z 5-327^{4}$ & $11 / 09 / 88$ & 372.2 & 60.5 & 105.4 & 2.40 & 32.0 & 1.12 & 1.13 & 43 & \\
\hline UZ5-335 & $08 / 29-30 / 89$ & 418.4 & 60.7 & 89.2 & 2.40 & 75.4 & 1.33 & 0.81 & 29 & Topopah Spring Member \\
\hline$U Z 5-345^{4}$ & $02 / 21 / 89$ & 366.4 & 60.5 & 84.3 & 2.40 & 39.3 & 1.35 & 0.78 & 26 & Topopah Spring Member \\
\hline$U Z 5-347^{5}$ & $03 / 16 / 89$ & 366.7 & 60.7 & 94.2 & 2.40 & 58.0 & 1.13 & 1.12 & 33 & Topopah Spring Member \\
\hline GTO-JJ-DB-1A-1-1 & $08 / 17-18 / 89$ & 444.6 & 60.7 & 86.9 & 2.34 & 91.2 & 1.41 & 0.66 & 23 & Tunnel bed 5 \\
\hline GTO-JJ-DB-1A-1-2 & $10 / 04 / 89$ & 418.9 & 60.7 & 82.6 & 2.34 & 85.9 & 1.39 & 0.68 & 24 & Tunnel bed 5 \\
\hline GTO-JJ-DB-1A-2-1 & $09 / 01 / 89$ & 434.9 & 60.7 & 86.4 & 2.34 & 89.5 & 1.38 & 0.69 & 23 & Tunnel bed 5 \\
\hline GTO-JJ-DB-1A-2-2 & $09 / 08 / 89$ & 449.5 & 60.7 & 88.1 & 2.34 & 91.3 & 1.40 & 0.67 & 23 & Tunnel bed 5 \\
\hline GTO-JJ-DB-1B-1-1 & $08 / 09 / 89$ & 429.2 & 60.7 & 83.8 & 2.34 & 88.8 & 1.40 & 0.67 & 22 & Tunnel bed 5 \\
\hline GT-EX-XH2-14 & $10 / 13 / 89$ & 389.2 & 61.2 & 85.6 & 2.34 & 80.1 & 1.23 & 0.91 & 28 & Tunnel bed 5 \\
\hline GT-EX-DH3-2 & $02 / 27 / 89$ & 435.4 & 61.0 & 96.3 & 2.34 & 102.5 & 1.18 & 0.98 & -- & Tunnel bed 5 \\
\hline GT-EX-DH3-3 $3^{5}$ & $03 / 03 / 89$ & 433.4 & 60.5 & 97.3 & 2.34 & 102.1 & 1.19 & 0.97 & 32 & Tunnel bed 5 \\
\hline \multicolumn{11}{|c|}{ Densely welded tuff } \\
\hline UZ13-62 & $02 / 14 / 89$ & 610.9 & 61.0 & 98.3 & 2.48 & 9.0 & 2.10 & 0.18 & 3 & Tiva Canyon Member \\
\hline GTG-LD-WB-3-1 ${ }^{5}$ & $03 / 10 / 89$ & 641.0 & 61.6 & 94.0 & 2.60 & 21.7 & 2.26 & 0.15 & 1 & Grouse Canyon Member \\
\hline GT-LD-AC2-5 $5^{4}$ & $02 / 10 / 89$ & 603.7 & 61.0 & 92.7 & 2.60 & 46.8 & 2.05 & 0.27 & 2 & Grouse Canyon Member \\
\hline GT-LD-AC2-17 & $04 / 10 / 89$ & 612.9 & 61.2 & 90.9 & 2.60 & 37.4 & 2.15 & 0.21 & 2 & Grouse Canyon Member \\
\hline GT-LD-AC2-18 & $05 / 22 / 89$ & 590.2 & 61.2 & 86.6 & 2.60 & 36.5 & 2.17 & 0.20 & 2 & Grouse Canyon Member \\
\hline GT-LD-AC2-25 & $04 / 18 / 89$ & 484.9 & 61.2 & 74.4 & 2.60 & 30.4 & 2.07 & 0.25 & 4 & Grouse Canyon Member \\
\hline GT-LD-AC2-26 5 & $04 / 12 / 89$ & 515.8 & 61.2 & 76.7 & 2.60 & 31.9 & 2.14 & 0.21 & 3 & Grouse Canyon Member \\
\hline
\end{tabular}


Table 4. Supplemental mechanical data for one-dimensional compression --Continued

\begin{tabular}{|c|c|c|c|c|c|c|c|c|c|c|}
\hline Sample name & Test date & $\begin{array}{c}\text { Total } \\
\text { mass } \\
\text { (grams) }\end{array}$ & $\begin{array}{c}\text { Core } \\
\text { diameter } \\
(\mathrm{mm})\end{array}$ & $\begin{array}{l}\text { Core } \\
\text { length } \\
(\mathrm{mm})\end{array}$ & $\begin{array}{l}\text { Assumed } \\
\text { grain } \\
\text { density } \\
\left(g / \mathrm{cm}^{3}\right)\end{array}$ & $\begin{array}{c}\begin{array}{c}\text { Total } \\
\text { water } \\
\text { volume } \\
\text { (mL) }\end{array} \\
\end{array}$ & $\begin{array}{l}\text { Initial dry } \\
\text { bulk } \\
\text { density } \\
\left(g / \mathrm{cm}^{3}\right)\end{array}$ & $\begin{array}{c}\text { Initial } \\
\text { void ratio } \\
\text { (pct) }\end{array}$ & $\begin{array}{l}\text { Permanent } \\
\text { strain }{ }^{2} \\
\text { (pct) }\end{array}$ & Formation ${ }^{3}$ \\
\hline \multicolumn{11}{|c|}{ Densely welded tuff-Continued } \\
\hline $\begin{array}{l}\text { GT-LD-AC2-41 } \\
\text { GT-LD-AC2-42 }\end{array}$ & $04 / 27 / 89$ & 567.6 & 61.2 & 82.6 & 2.60 & 34.6 & 2.19 & 0.19 & 2 & Grouse Canyon Member \\
\hline $\begin{array}{l}\text { GT-LD-AC2-42 } \\
\text { GT-LD-AC2-55 }\end{array}$ & $05 / 02 / 89$ & 527.8 & 61.2 & 78.0 & 2.60 & 32.2 & 2.16 & 0.20 & 2 & Grouse Canyon Member \\
\hline $\begin{array}{l}\text { GT-LD-AC2-55 } \\
\text { GT-LD-AC2-62 }\end{array}$ & $05 / 25-26 / 89$ & 584.8 & 61.2 & 87.9 & 2.60 & 41.8 & 2.10 & 0.24 & 5 & Grouse Canyon Member \\
\hline $\begin{array}{l}\text { GT-LD-AC2-62 } \\
\text { GT-LD-AC2-63 }\end{array}$ & 06/01-02/89 & 546.5 & 61.2 & 81.3 & 2.60 & 33.8 & 2.14 & 0.21 & 3 & Grouse Canyon Member \\
\hline $\begin{array}{l}\text { GT-LD-AC2-63 } \\
\text { GT-LD-AC2-118 }\end{array}$ & 06/09/89 & 429.2 & 61.2 & 63.5 & 2.60 & 26.6 & 2.15 & $\begin{array}{l}0.21 \\
0.18\end{array}$ & $\begin{array}{l}2 \\
2\end{array}$ & $\begin{array}{l}\text { Grouse Canyon Member } \\
\text { Grouse Canyon Member }\end{array}$ \\
\hline & $\begin{array}{c}07 / 31- \\
08 / 01 / 89\end{array}$ & 484.4 & 60.7 & 72.4 & 2.60 & 24.4 & 2.20 & & & \\
\hline $\begin{array}{l}\text { GT-DD-A-7 } \\
\text { GT-DD-A-10 }\end{array}$ & $12 / 05-06 / 89$ & 399.1 & 61.5 & 62.2 & 2.60 & 32.3 & 1.99 & 0.31 & 6 & Grouse Canyon Member \\
\hline GT-DD-A-10 & $11 / 28-29 / 89$ & 458.2 & 61.2 & 71.9 & 2.60 & 30.0 & 2.02 & 0.28 & 6 & Grouse Canyon Member \\
\hline
\end{tabular}

ID ${ }_{1}^{1}$ Sources for grain density data: Manger. 1965; Price. 1983: Scott and others. 1983; Anderson. 1984; Rush and others, 1984: Tillerson and Nimick. 1984; Lappin and Nimick. 1985; Zimmerman and Finley, 1987: and J.P. Rousseau and W. Thordarson. U.S. Geological Survey, written commun.. 1989.

2Permanent strain is based on the sample length after the completion of a test (while subject to an axial load of about 9 kiloNeutons).

'Pertion of Tiva Canyon Mers

Sources: Byers and others, 1976; R.W. Spengler. U.S. Geological Survey, written commun.. 1985: M.P. Chornack, U.S. Geological Survey, personal commun.. 1989

${ }^{4}$ Test using smooth drainage plates; all other tests used grooved drainage plates.

SCore temperature monitored during compression. 


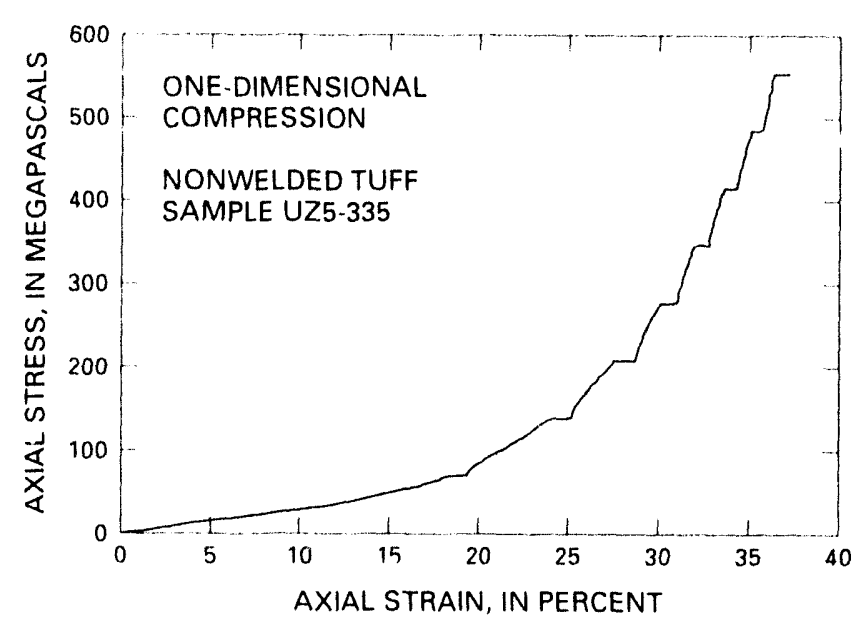

Figure 18. Relation between axial stress and axial strain for one-dimensional compression of a nonwelded tuff sample UZ5-335.

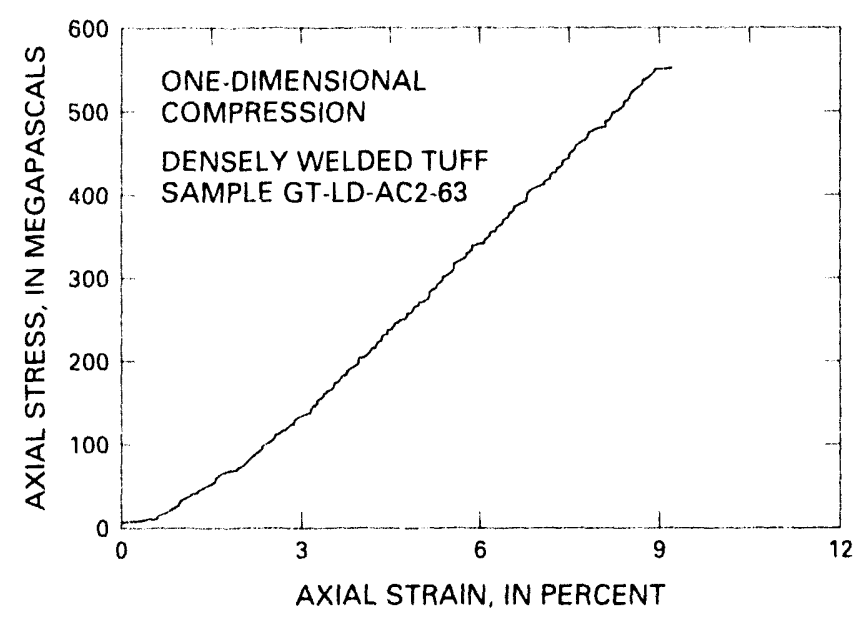

Figure 19. Relation between axial stress and axial strain for one-dimensional compression of a densely welded tuff sam. ple GT-LD-AC2-63.

from 16 to 60 percent of the total available water for nonwelded tuff cores, and 2 to 28 percent for densely welded tuff cores. The average extraction success (for compression tests that produced water) was 41 percent for nonwelded tuff cores, and 11 percent for densely welded tuff cores. Pore-water extraction success was calculated as the total volume of water extracted divided by the total volume of pore water in the test specimen. The degree of extraction success increases as the initial moisture content of the test core increases. This relation is illustrated by the nonwelded tuff test data on figure 22 , and to a lesser extent by the densely welded tuff test data on the same graph.

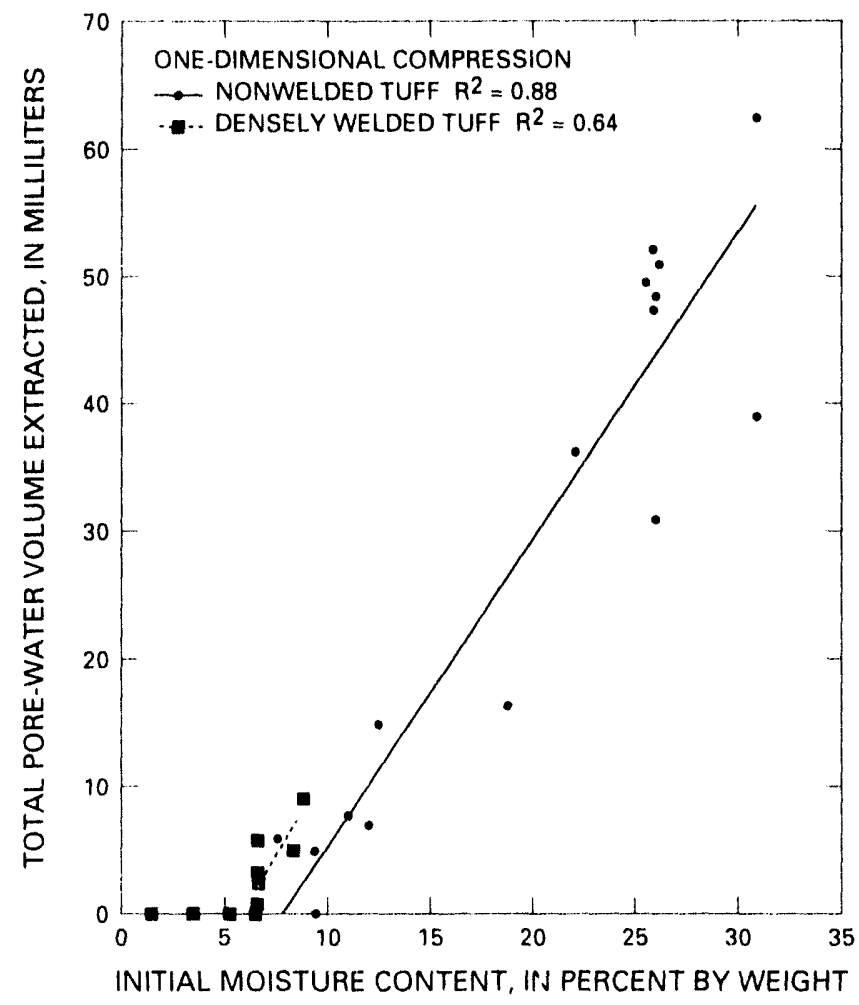

Figure 20. Relation between initial moisture content and volume of pore water extracted from cores using one-dimensional compression with gas injection.

The temperature of the test core during compression was measured during five of the 32 onedimensional compression tests. The core temperature was measured using a 30-gauge type $\mathrm{K}$ thermocouple that was threaded from the base of the core out through the water collection system. No temperature changes (except the initial warming of the test core from refrigerated conditions to room temperature) were noted during any of these tests. The core temperature during compression was not monitored on a routine basis because installation of the thermocouple significantly lengthened the test set-up time and increased the risk of pore-water leakage; the five measurements made were believed to be sufficient to demonstrate that the temperature of a core does not increase during onedimensional compression under the loading conditions used during this study.

\section{ADDITIONAL DATA FOR PORE-WATER EXTRACTION USING GAS INJECTION}

As previously mentioned, gas injection can be used to enhance pore water from a tuff core in addition 
to the pore water produced by compression. Detailed information concerning pore-water extraction using gas injection in conjunction with triaxial compression and one-dimensional compression is included in tables 5 and 6, respectively. Throughout this study, nitrogen gas was used for gas injection. Ultra-high purity (grade 5) nitrogen was chosen for its low moisture content (greater than 99.999 percent nitrogen, less than 1 part per million by volume water vapor) and low cost. (Nitrogen also has the additional advantage of not containing hydrogen, oxygen, or carbon isotopes that could introduce contamination if the isotopic composition of the extracted pore water were under examination.)

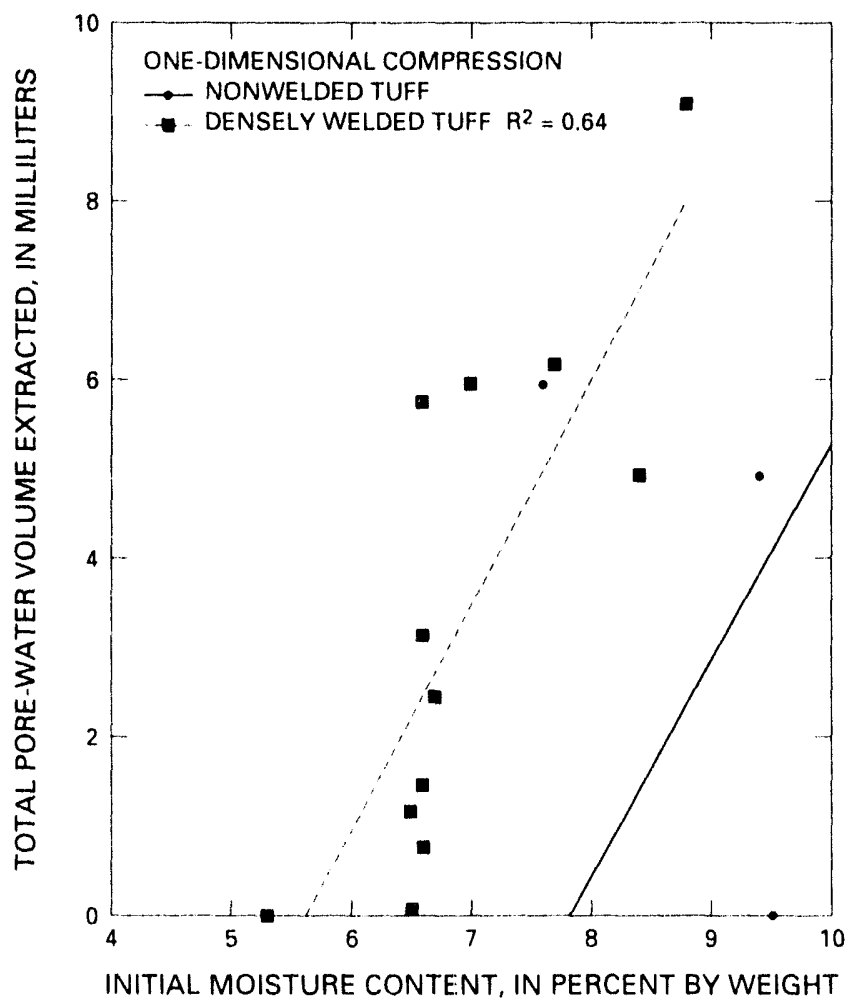

Figure 21. Relation between initial moisture content and volume of pore water extracted from densely welded cores using one-dimensional compression with gas injection. Only cores that had initial moisture contents less than 10 percent are shown

\section{Mechanics of Pore-Water Extraction by Gas Injection}

In a core that is fully water saturated, gas injection creates a pressure gradient in the pore water that, in turn, causes the water to flow out of the core. Darcy's Law describes this relation (Freeze and Cherry, 1979):

$$
Q=-K d h / d l A
$$

where:

$$
\begin{aligned}
Q & =\text { discharge or flow } 1 \text { ate } \\
K & =\text { hydraulic conductivity } \\
d h / d l & =\text { hydraulic gradient } \\
A & =\text { cross-sectional area of flow }
\end{aligned}
$$

The negative sign indicates flow is down the hydraulic gradient, from higher total head to lower total head. Hydraulic conductivity refers only to the flow of water; permeability $(k)$ is used to describe flow of fluids other than water.

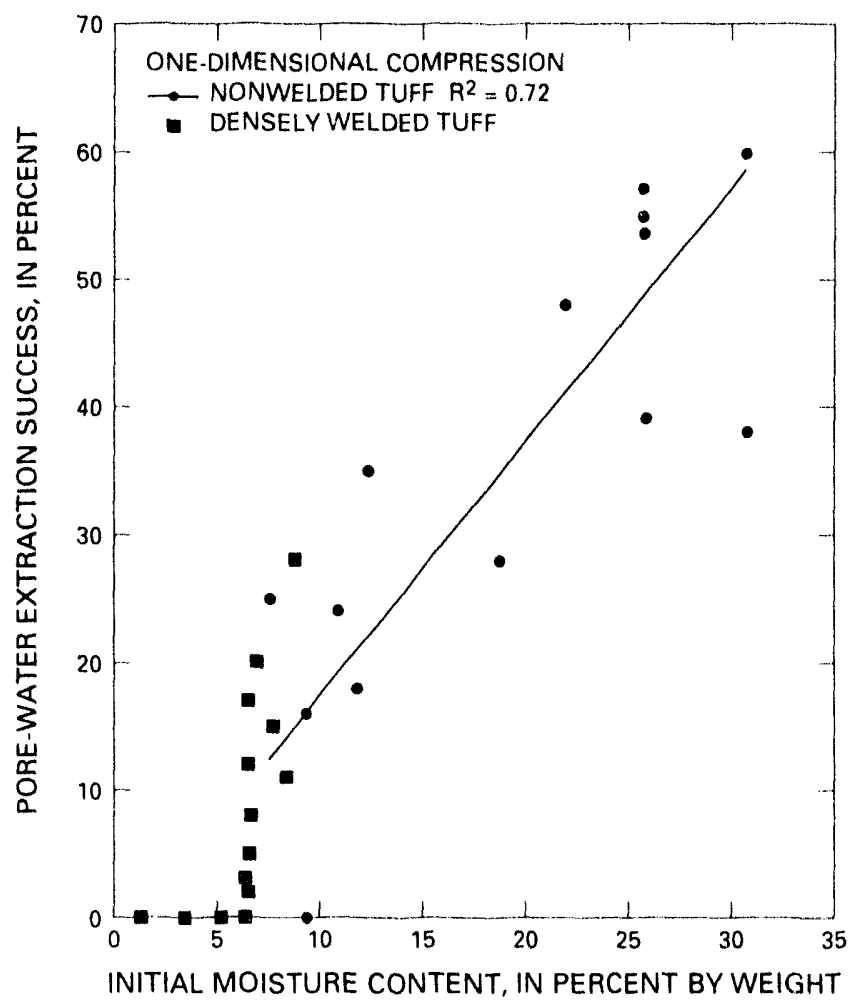

Figure 22. Relation between initial moisture content and pore-water extraction success for cores tested using onedimensional compression.

Applying gas pressure to one end of the core increases the hydraulic gradient. However, the rate of water discharge from the other end of the core also is dependent on the hydraulic conductivity and the crosssectional area. For cores of the same rock type (nonwelded tuffs, for example), the cross-sectional area of flow is approximately the same for any two test cores that have the same diameter. The hydraulic conductivity of any two cores may not be similar because the value of hydraulic conductivity will depend not only on 
Table 5. Data for triaxial compression using gas injection

[MPa, megapascals; $\mathrm{mL} / \mathrm{min}$, milliliters per minute; min, minutes; $\mathrm{mL}$, milliliters; -, no data available; >. greater than; <, less than]

\begin{tabular}{|c|c|c|c|c|c|c|c|}
\hline Sample name & $\begin{array}{c}\text { Axlal stress } \\
\text { (MPa) }\end{array}$ & $\begin{array}{c}\text { Gas } \\
\text { injection } \\
\text { pressure } \\
\text { (MPa) }\end{array}$ & $\begin{array}{c}\text { Gas flow } \\
\text { rate }^{2} \\
\text { (mUmin) }\end{array}$ & $\begin{array}{l}\text { Flow } \\
\text { duration } \\
\text { (min) }\end{array}$ & $\begin{array}{c}\text { Cumulative } \\
\text { injection } \\
\text { time } \\
\text { (min) }\end{array}$ & $\begin{array}{l}\text { Cumulative } \\
\text { water } \\
\text { volume4 } \\
\text { (mL) }\end{array}$ & Notes \\
\hline \multicolumn{8}{|c|}{ Nonwelded tuff } \\
\hline \multirow[t]{3}{*}{ UZA-182 } & 97 & 2.8 & 0 & 4 & 4 & 0 & \\
\hline & 97 & 2.8 & (14) & 7 & 11 & 2 & \\
\hline & 97 & 1.4 & -- & 15 & 36 & 4 & \\
\hline UZ4-190 & 152 & 0.3 & - & 50 & 50 & 0 & \\
\hline \multirow[t]{26}{*}{ UZA-237 } & 117 & 4.1 & 0 & 5 & 5 & 0 & \\
\hline & 117 & 4.1 & (6) & 5 & 10 & 2 & \\
\hline & 117 & 4.1 & (9) & 3 & 13 & 3 & \\
\hline & 117 & 4.1 & (13) & 3 & 16 & 3.5 & \\
\hline & 117 & 4.1 & (16) & 2 & 18 & 4 & \\
\hline & 117 & 4.1 & (18) & 1 & 19 & 4.5 & \\
\hline & 117 & 4.1 & (22) & 1 & 20 & 5 & \\
\hline & 117 & 4.1 & (22) & 3 & 23 & 5.5 & \\
\hline & 117 & 4.1 & (22) & 1 & 24 & 6 & \\
\hline & 117 & 4.1 & (22) & 2 & 26 & 6.5 & \\
\hline & 117 & 4.1 & (22) & 8 & 34 & 7 & \\
\hline & 117 & 4.1 & -- & 8 & 42 & 7.5 & \\
\hline & 117 & 4.1 & -- & 2 & 44 & 8.5 & \\
\hline & 117 & 4.1 & - & 2 & 46 & 9.5 & \\
\hline & 117 & 6.9 & - & 5 & 51 & 10 & \\
\hline & 117 & 6.9 & - & 2 & 53 & 10.5 & \\
\hline & 117 & 6.9 & -- & 4 & 57 & 11 & \\
\hline & 117 & 6.9 & -- & 2 & 59 & 11.5 & \\
\hline & 117 & 6.9 & -- & 2 & 61 & 12 & \\
\hline & 117 & 6.9 & -- & 2 & 63 & 12.5 & \\
\hline & 117 & 9.7 & -- & 4 & 67 & 13 & \\
\hline & 117 & 9.7 & -- & 2 & 69 & 13.5 & \\
\hline & 117 & 9.7 & - & 3 & 72 & 14 & \\
\hline & 117 & 9.7 & - & 3 & 75 & 14.5 & \\
\hline & 117 & 9.7 & -- & 6 & 81 & 15 & \\
\hline & 152 & 4.1 & (51) & 6 & 87 & 15 & \\
\hline
\end{tabular}


Table 5. Data for triaxial compression using gas injection --Continued

\begin{tabular}{|c|c|c|c|c|c|c|c|}
\hline Sample name & $\begin{array}{c}\text { Axial stress } \\
\text { (MPa) }\end{array}$ & $\begin{array}{c}\text { Gas } \\
\text { injection } \\
\text { pressure' } \\
\text { (MPa) }\end{array}$ & $\begin{array}{c}\text { Gas flow } \\
\text { rate } \\
\text { (mL/min) }\end{array}$ & $\begin{array}{l}\text { Flow } \\
\text { duration } \\
\text { (min) }\end{array}$ & $\begin{array}{l}\text { Cumulative } \\
\text { Injection } \\
\text { time } \\
\text { (min) }\end{array}$ & $\begin{array}{l}\text { Cumulative } \\
\text { water } \\
\text { volume` } \\
\text { (mL) }\end{array}$ & Notes \\
\hline & & & \multicolumn{4}{|c|}{ Nonwelded tuff-Continued } & \\
\hline \multirow{17}{*}{ UZ4-238 } & 117 & 4.1 & 0 & 8 & 8 & 0 & \\
\hline & 117 & 4.1 & (12) & 2 & 10 & 2.5 & \\
\hline & 117 & 4.1 & (12) & 3 & 13 & 3 & \\
\hline & 117 & 4.1 & (15) & 2 & 15 & 4 & \\
\hline & 117 & 4.1 & (30) & 1 & 16 & 4.5 & \\
\hline & 117 & 4.1 & (30) & 2 & 18 & 5 & \\
\hline & 117 & 4.1 & (30) & 3 & 21 & 5.5 & \\
\hline & 117 & 4.1 & (30) & 2 & 23 & 6 & \\
\hline & 117 & 6.9 & - & 15 & 38 & 9.5 & \\
\hline & 117 & 6.9 & -. & 5 & 43 & 10.5 & \\
\hline & 117 & 6.9 & -- & 2 & 45 & 11 & \\
\hline & 117 & 6.9 & -. & 5 & 50 & 12 & \\
\hline & 117 & 6.9 & - & 2 & 52 & 12.5 & \\
\hline & 117 & 6.9 & - & 5 & 57 & 13.5 & \\
\hline & 117 & 6.9 & - & 3 & 60 & 14 & \\
\hline & 117 & 6.9 & -- & 3 & 63 & 14.5 & \\
\hline & 117 & 6.9 & -. & 7 & 70 & 15 & \\
\hline \multirow[t]{9}{*}{ UZ4-240 } & 76 & 4.1 & 0 & 3 & 3 & 0 & \\
\hline & 76 & 4.1 & (15) & 4 & 7 & 0.5 & \\
\hline & 76 & 4.1 & (15) & 1 & 8 & 1 & \\
\hline & 76 & 4.1 & (20) & 2 & 10 & 1.5 & \\
\hline & 76 & 4.1 & (20) & 7 & 17 & 2.5 & \\
\hline & 76 & 4.1 & -- & 10 & 27 & 5 & \\
\hline & 76 & 4.1 & -- & 4 & 31 & 6 & \\
\hline & 76 & 4.1 & - & 5 & 36 & 8 & \\
\hline & 76 & 6.9 & - & 4 & 40 & 11.5 & \\
\hline \multirow[t]{5}{*}{ UZ4-241 } & 117 & 4.1 & 0 & 4 & 4 & 0 & \\
\hline & 117 & 4.1 & -- & 2 & 6 & 2 & \\
\hline & 117 & 4.1 & -- & 2 & 8 & 3.5 & \\
\hline & 117 & 4.1 & -- & 6 & 14 & 4.5 & \\
\hline & 117 & 4.1 & - & 16 & 30 & 7.5 & \\
\hline
\end{tabular}


Table 5. Data for triaxial compression using gas injection --Continued

\begin{tabular}{|c|c|c|c|c|c|c|}
\hline Sample name & $\begin{array}{l}\text { Axial stress } \\
\text { (MPa) }\end{array}$ & $\begin{array}{c}\text { Gas } \\
\text { Injection } \\
\text { pressure' } \\
\text { (MPa) }\end{array}$ & $\begin{array}{l}\text { Gas flow } \\
\text { rate } \\
\text { (mLmin) }\end{array}$ & $\begin{array}{c}\text { Flow } \\
\text { duration } \\
\text { (min) }\end{array}$ & $\begin{array}{l}\text { Cumulative } \\
\text { Injection } \\
\text { time } \\
\text { (min) }\end{array}$ & $\begin{array}{l}\text { Cumulath } \\
\text { water } \\
\text { volume } \\
\text { (mL) }\end{array}$ \\
\hline & \multicolumn{6}{|c|}{ Nonwelded tuff-Continued } \\
\hline \multirow[t]{2}{*}{ UZ4-241 (cont.) } & 117 & 4.1 & -- & 14 & 44 & 9 \\
\hline & 117 & 4.1 & - & 5 & 49 & 11 \\
\hline \multirow[t]{6}{*}{ UZ4-242 } & 165 & 2.8 & $\mathbf{0}$ & 9 & 9 & 0 \\
\hline & 165 & 4.1 & 0 & 6 & 15 & 0 \\
\hline & 165 & 4.1 & -- & 4 & 19 & 6 \\
\hline & 165 & 4.1 & -- & 11 & 30 & 8 \\
\hline & 165 & 6.9 & .- & 20 & 50 & 11.5 \\
\hline & 165 & 6.9 & .- & 20 & 70 & 13.5 \\
\hline
\end{tabular}

UZ5-223

UZ5-235

0

0.2

0.2

0

0

due to confining fluid leakage.

Gas injection duration short because platens were

displaced to nearly maximum extent at the start of injection; continued displacement of platens caused end of test to prevent damage to compression fittings on platens. 
Table 5. Data for triaxial compression using gas injection --Continued

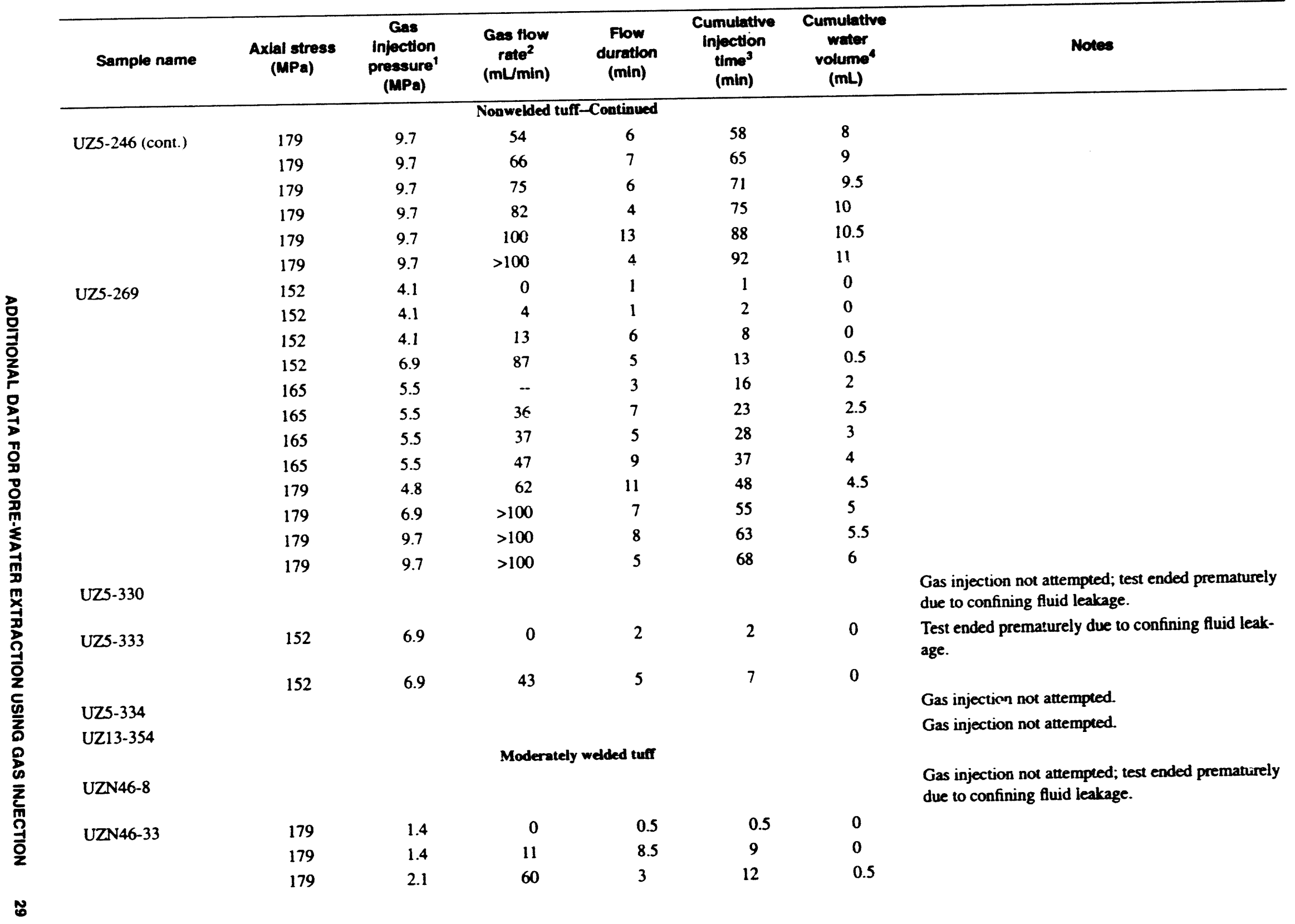


Table 5. Data for triaxial compression using gas injection --Continued

\begin{tabular}{|c|c|c|c|c|c|c|}
\hline Sample name & $\begin{array}{c}\text { Axial stress } \\
\text { (MPa) }\end{array}$ & $\begin{array}{c}\text { Gas } \\
\text { Injection } \\
\text { pressure' } \\
\text { (MPa) }\end{array}$ & $\begin{array}{l}\text { Gas flow } \\
\text { rate }^{2} \\
\text { (mL/min) }\end{array}$ & $\begin{array}{l}\text { Flow } \\
\text { duration } \\
\text { (min) }\end{array}$ & $\begin{array}{l}\text { Cumulative } \\
\text { Injection } \\
\text { time } \\
\text { (min) }\end{array}$ & $\begin{array}{r}\text { Cumula } \\
\text { watt } \\
\text { volum } \\
\text { (mL) }\end{array}$ \\
\hline & \multicolumn{6}{|c|}{ Moderately welded tuff-Continued } \\
\hline \multirow[t]{12}{*}{ UZN46-33 (cont.) } & 179 & 2.1 & 62 & 1 & 13 & 1 \\
\hline & 179 & 2.1 & 64 & 1 & 14 & 1. \\
\hline & 179 & 2.1 & 68 & 2 & 16 & 2 \\
\hline & 179 & 2.1 & 77 & 4 & 20 & 2. \\
\hline & 179 & 2.1 & 86 & 4 & 24 & 3 \\
\hline & 179 & 2.1 & $>100$ & 10 & 34 & 4 \\
\hline & 179 & 2.1 & $>100$ & 10 & 44 & 5 \\
\hline & 179 & 4.1 & $>100$ & 5 & 49 & 5. \\
\hline & 179 & 4.1 & $>100$ & 15 & 64 & 6 \\
\hline & 179 & 4.1 & $>100$ & 20 & 84 & 6 \\
\hline & 179 & 6.2 & $>100$ & 10 & 94 & 6 \\
\hline & 193 & 0.7 & 30 & 10 & 104 & 6 \\
\hline
\end{tabular}

${ }^{1}$ Gas injection pressure measured at regulator on gas tank before entry into top of triaxial cell. Accuracy of measurement is $\pm 0.3 \mathrm{MPa}$.

${ }^{2}$ Gas flow rate measured after water collection using flow meters; for values $<100 \mathrm{~mL}$ min, meter accuracy is $\pm 1 \mathrm{~mL} / \mathrm{min}$; for values $>100 \mathrm{~mL} / \mathrm{min}$, meter accuracy is $\pm 10 \mathrm{~mL}$ min. Where rate is enclosed in parentheses (). flow rate was approximated by measuring the time needed for gas to fill a 30 -mL syringe; measurement accuracy is approximately $\pm 1 \mathrm{~mL} / \mathrm{min}$ for rates $<10 \mathrm{~mL} / \mathrm{min}$. $\pm 5 \mathrm{~mL} / \mathrm{min}$ for rates between 10 and $50 \mathrm{~mL} / \mathrm{min}$. and $\pm 10 \mathrm{~mL} / \mathrm{min}$ for rates $>50 \mathrm{~mL} / \mathrm{min}$. Gas flow rate value represents rate at the end of the indicated flow duration.

${ }^{3}$ Cumulative time, in minutes, since the start of gas injection.

${ }^{4}$ Cumulative water volume recovered by gas injection only. Although water volumes increase in discrete steps in the table, expulsion of water was gradual; water volume data appear in steps because measurements of recovered water volume were not made as frequently as measurements of gas flow rate. 
Table 6. Data for one-dimensional compression using gas injection

[MPa. megapascals; $\mathrm{mL}$ min. milliliters per munute: $\mathrm{min}$. minutes: $\mathrm{mL}$. milliliters: <, less than: >, greater than: $-\cdots$, no data available]

\begin{tabular}{|c|c|c|c|c|c|c|c|}
\hline Sample name & $\begin{array}{l}\text { Axial } \\
\text { stress } \\
\text { (MPa) }\end{array}$ & $\begin{array}{c}\text { Gas } \\
\text { Injection } \\
\text { pressure' } \\
\text { (MPa) }\end{array}$ & $\begin{array}{l}\text { Gas flow } \\
\text { rate }{ }^{2} \\
\text { (mL } \\
\text { min) }\end{array}$ & $\begin{array}{l}\text { Flow } \\
\text { duration } \\
\text { (min) }\end{array}$ & $\begin{array}{l}\text { Cumulative } \\
\text { Injection time } \\
\text { (min) }\end{array}$ & $\begin{array}{l}\text { Cumulative } \\
\text { water } \\
\text { volume } \\
\text { (mL) }\end{array}$ & Notes \\
\hline \multicolumn{8}{|r|}{ Iniection unsuccessful due to mechanical failure of } \\
\hline UZ4-115 & 427 & 1.4 & $\mathbf{0}$ & 2 & 2 & $\mathbf{0}$ & $\begin{array}{l}\text { Injection unsuccessful due to mechanical failure of } \\
\text { drainage plates. }\end{array}$ \\
\hline & 427 & 2.8 & 0 & 3 & 5 & 0 & \\
\hline & 427 & 4.1 & 0 & 2 & 7 & 0 & \\
\hline & 427 & 6.9 & 0 & 3 & 10 & 0 & \\
\hline & 427 & 10.3 & 0 & 16 & 26 & 0 & \\
\hline \multirow[t]{9}{*}{ UZ4-338 } & 395 & 1.4 & 0 & 3 & 3 & 0 & Initial load to $434 \mathrm{MPa}$, then decrease to $395 \mathrm{MPa}$. \\
\hline & 395 & 2.8 & 0 & 3 & 6 & 0 & \\
\hline & 395 & 2.8 & (15) & 18 & 24 & 0 & \\
\hline & 395 & 2.8 & 0 & 6 & 30 & 0 & After unload to 0 axial stress and reload to $395 \mathrm{MPa}$. \\
\hline & 395 & 4.1 & 0 & 1 & 31 & 0 & \\
\hline & 395 & 5.5 & 0 & 1 & 32 & 0 & \\
\hline & 395 & 6.9 & 0 & 3 & 35 & 0 & \\
\hline & 395 & 6.9 & 1 & 3 & 38 & $\mathbf{0}$ & \\
\hline & 395 & 6.9 & 2 & 2 & 40 & 0 & \\
\hline \multirow[t]{2}{*}{ UZS-217 } & 221 & 2.8 & 0 & 2 & 2 & 0 & \\
\hline & 221 & 2.8 & (15) & 2 & 4 & trace & \\
\hline \multirow[t]{9}{*}{ UZ5-230 } & 351 & 2.8 & 0 & 5 & 5 & 0 & Initial load to $434 \mathrm{MPa}$, then decrease to $351 \mathrm{MPa}$. \\
\hline & 351 & 5.5 & 0 & 2 & 7 & 0 & \\
\hline & 351 & 5.5 & $(30)$ & 4 & 11 & 1 & \\
\hline & 351 & 5.5 & 1 & 2 & 13 & 1 & After reload to $434 \mathrm{MPa}$, then decrease to $351 \mathrm{MPa}$. \\
\hline & 351 & 5.5 & 4 & 3 & 16 & 1 & \\
\hline & 351 & 5.5 & 7 & 4 & 20 & 1 & \\
\hline & 351 & 5.5 & 8 & 9 & 29 & 1 & \\
\hline & 351 & 5.5 & 10 & 2 & 31 & 3 & \\
\hline & 351 & 5.5 & 14 & 8 & 39 & 3 & \\
\hline
\end{tabular}


Table 6. Data for one-dimensional compression using gas injection --Continued

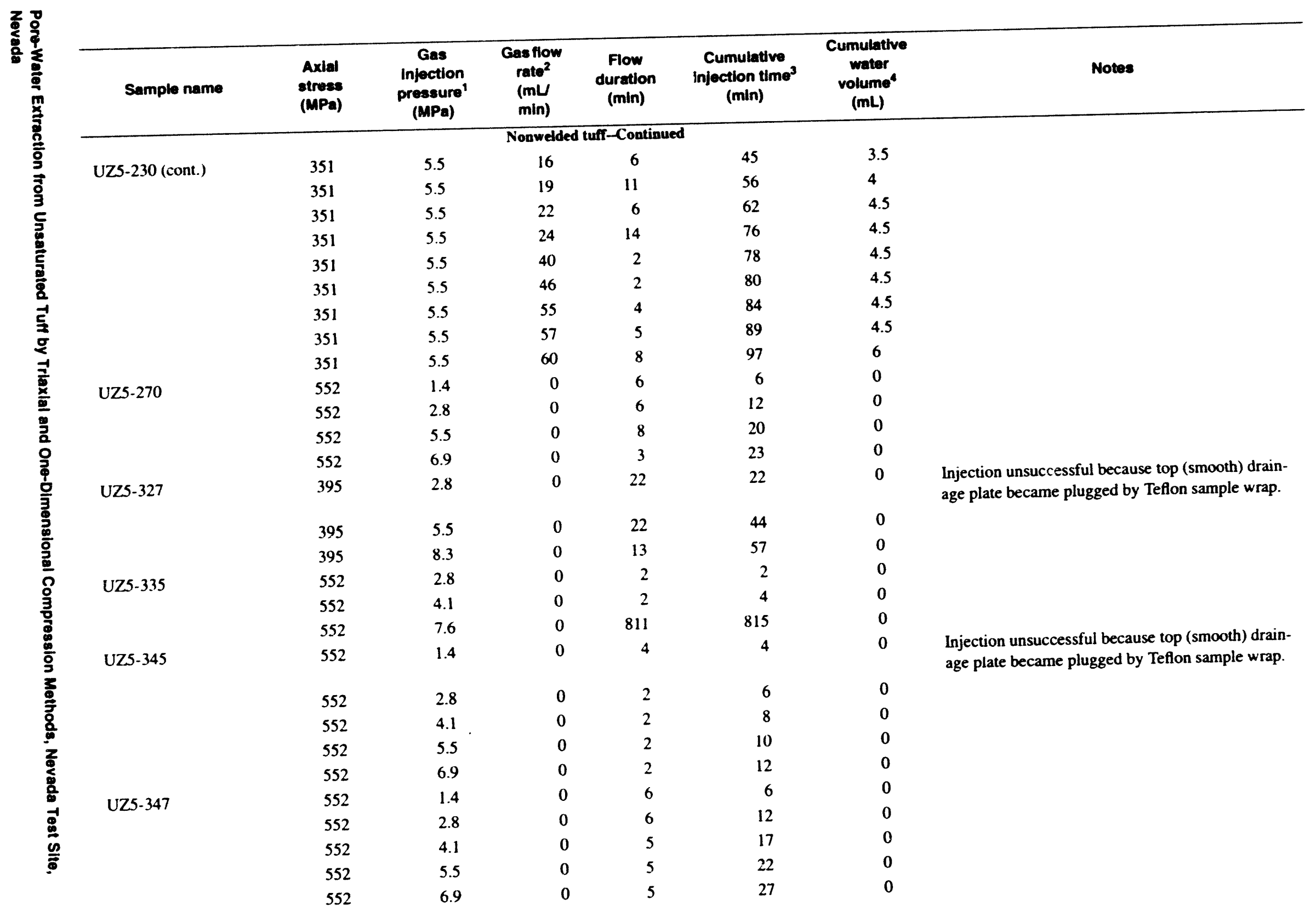


Table 6. Data for one-dimensional compression using gas injection --Continued

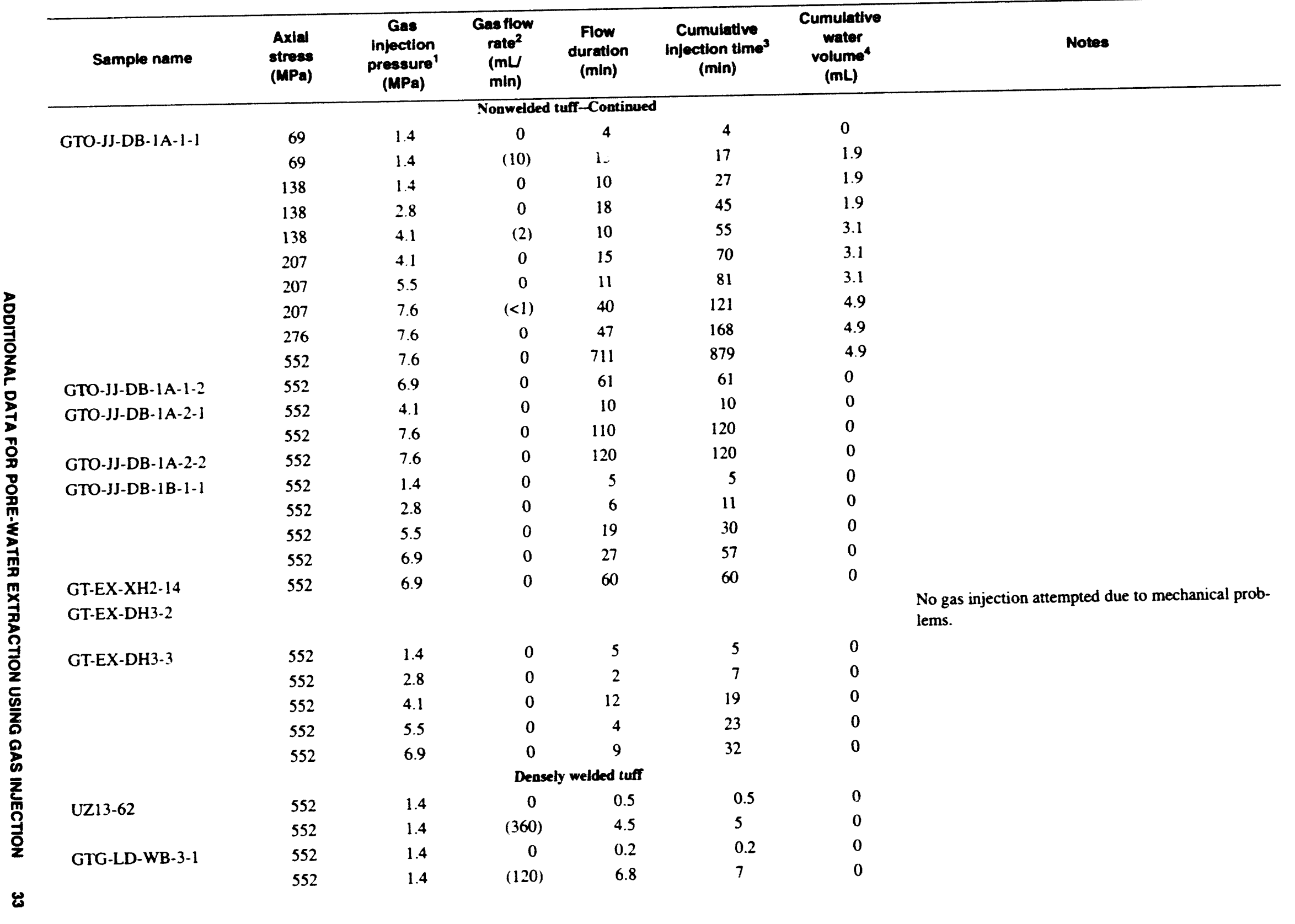


Table 6. Data for one-dimensional compression using gas injection --Continued

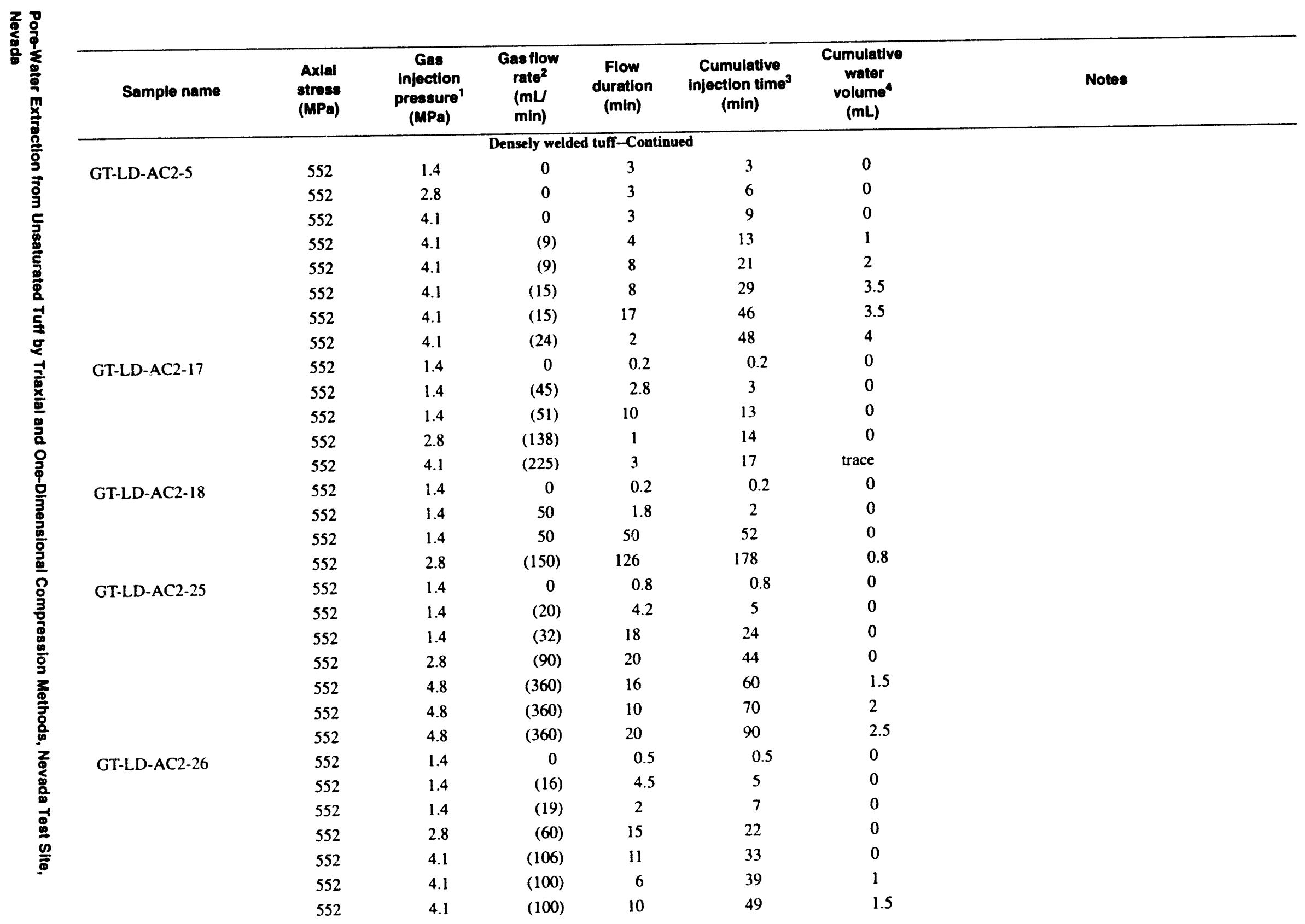


Table 6. Data for one-dimensional compression using gas injection --Continued

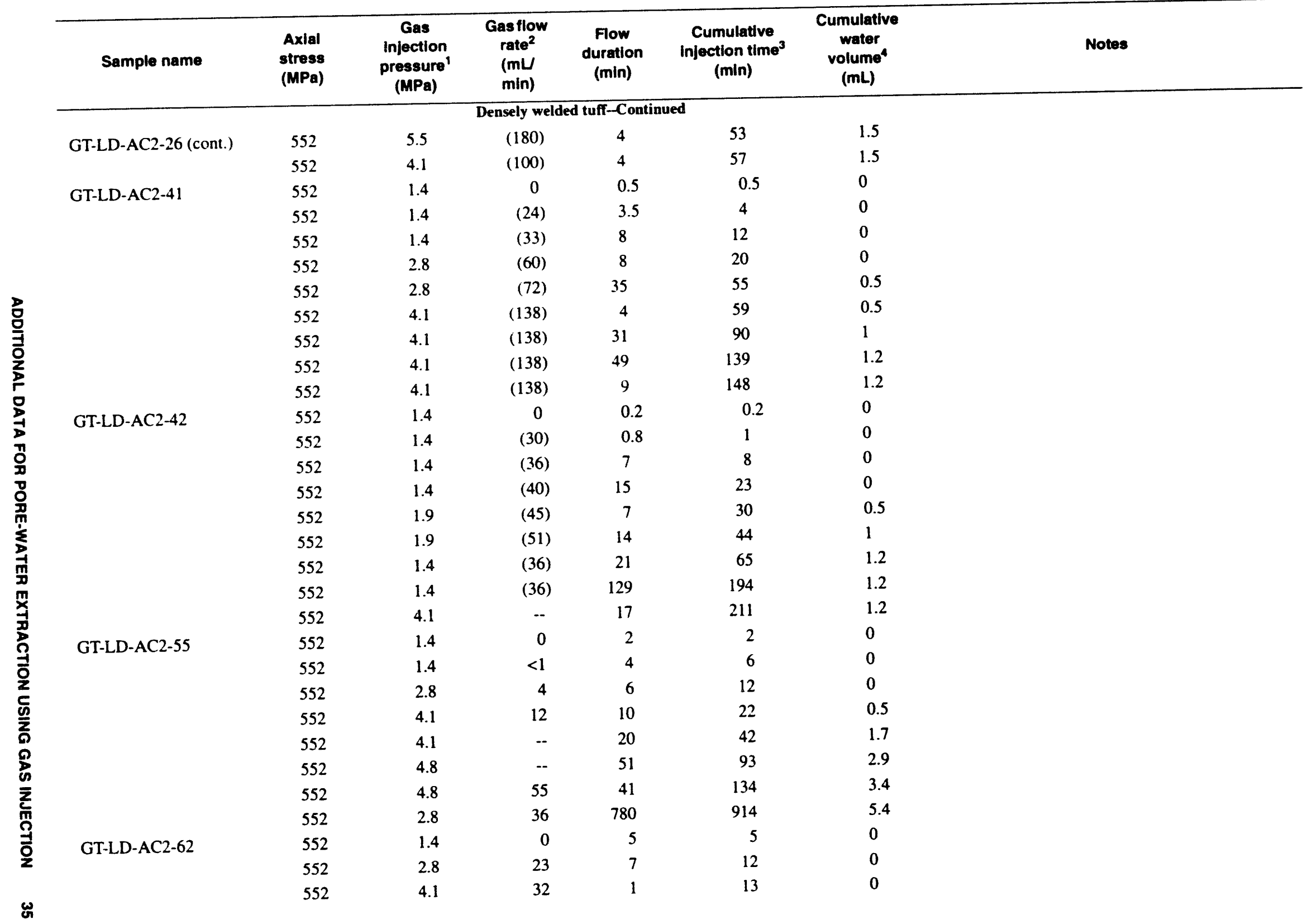


w Table 6. Data for one-dimensional compression using gas injection --Continued

\begin{tabular}{|c|c|c|c|c|c|c|c|}
\hline \multirow{12}{*}{ GT-LD-AC2-62 (cont.) } & & & ensely nweld & d tuff-Conti & & & \\
\hline & 552 & 4.1 & 45 & 13 & 26 & 0.6 & \\
\hline & 552 & 4.1 & 53 & 10 & 36 & 1.1 & \\
\hline & 552 & 4.1 & 62 & 14 & 50 & 1.6 & \\
\hline & 552 & 4.1 & 70 & 10 & 60 & 1.8 & \\
\hline & 552 & 4.1 & 80 & 20 & 80 & 1.8 & \\
\hline & 552 & 4.1 & 82 & 15 & 85 & 2.2 & \\
\hline & 552 & 4.1 & 90 & 20 & 105 & 2.4 & \\
\hline & 552 & 4.1 & 96 & 20 & 125 & 2.7 & \\
\hline & 552 & 4.1 & 100 & 10 & 135 & 2.8 & \\
\hline & 552 & 4.1 & $>100$ & 15 & 150 & 3.2 & \\
\hline & 552 & 4.1 & $>100$ & 42 & 192 & 3.4 & \\
\hline \multirow[t]{17}{*}{ GT-LD-AC2-63 } & 552 & 2.8 & 74 & 831 & 1023 & 5.8 & \\
\hline & $\begin{array}{l}552 \\
552\end{array}$ & 1.4 & 0 & 0.5 & 0.5 & 0 & \\
\hline & $\begin{array}{l}552 \\
552\end{array}$ & 1.4 & $<1$ & $\begin{array}{l}3.5 \\
0.5\end{array}$ & $\begin{array}{l}4 \\
4.5\end{array}$ & $\begin{array}{l}0 \\
0\end{array}$ & \\
\hline & $\begin{array}{l}552 \\
552\end{array}$ & $\begin{array}{l}2.8 \\
2.8\end{array}$ & $\begin{array}{l}37 \\
60\end{array}$ & $\begin{array}{l}0.5 \\
0.5\end{array}$ & $\begin{array}{l}4.3 \\
5\end{array}$ & $\begin{array}{l}0 \\
0\end{array}$ & \\
\hline & 552 & 2.8 & 78 & 5 & 10 & 0.5 & \\
\hline & 552 & 2.8 & 91 & 4 & 14 & 0.8 & \\
\hline & 552 & 2.8 & 103 & 4 & 18 & 1.0 & \\
\hline & 552 & 2.8 & 110 & 10 & 28 & 1.0 & \\
\hline & 552 & 2.8 & 125 & 7 & 35 & 1.3 & \\
\hline & 552 & 2.8 & 140 & 10 & 45 & 1.6 & \\
\hline & 552 & 2.8 & 150 & 16 & 61 & 1.8 & \\
\hline & 552 & 2.8 & 175 & 38 & 99 & 2.1 & \\
\hline & 552 & 2.8 & 180 & 33 & 132 & 2.6 & \\
\hline & 552 & 2.8 & 180 & 14 & 146 & 3.0 & \\
\hline & 552 & 2.8 & 180 & 21 & 167 & 3.0 & \\
\hline & 552 & 2.8 & 200 & 13 & 190 & 3.0 & \\
\hline & 552 & 4.1 & -- & 2 & 192 & 3.2 & \\
\hline \multirow{2}{*}{ GT-LD-AC2-118 } & 414 & 1.4 & 0 & 0.2 & 0.2 & 0 & \\
\hline & 414 & 1.4 & $>100$ & 0.3 & 0.5 & 0 & \\
\hline
\end{tabular}


Table 6. Data for one-dimensional compression using gas injection -Continued

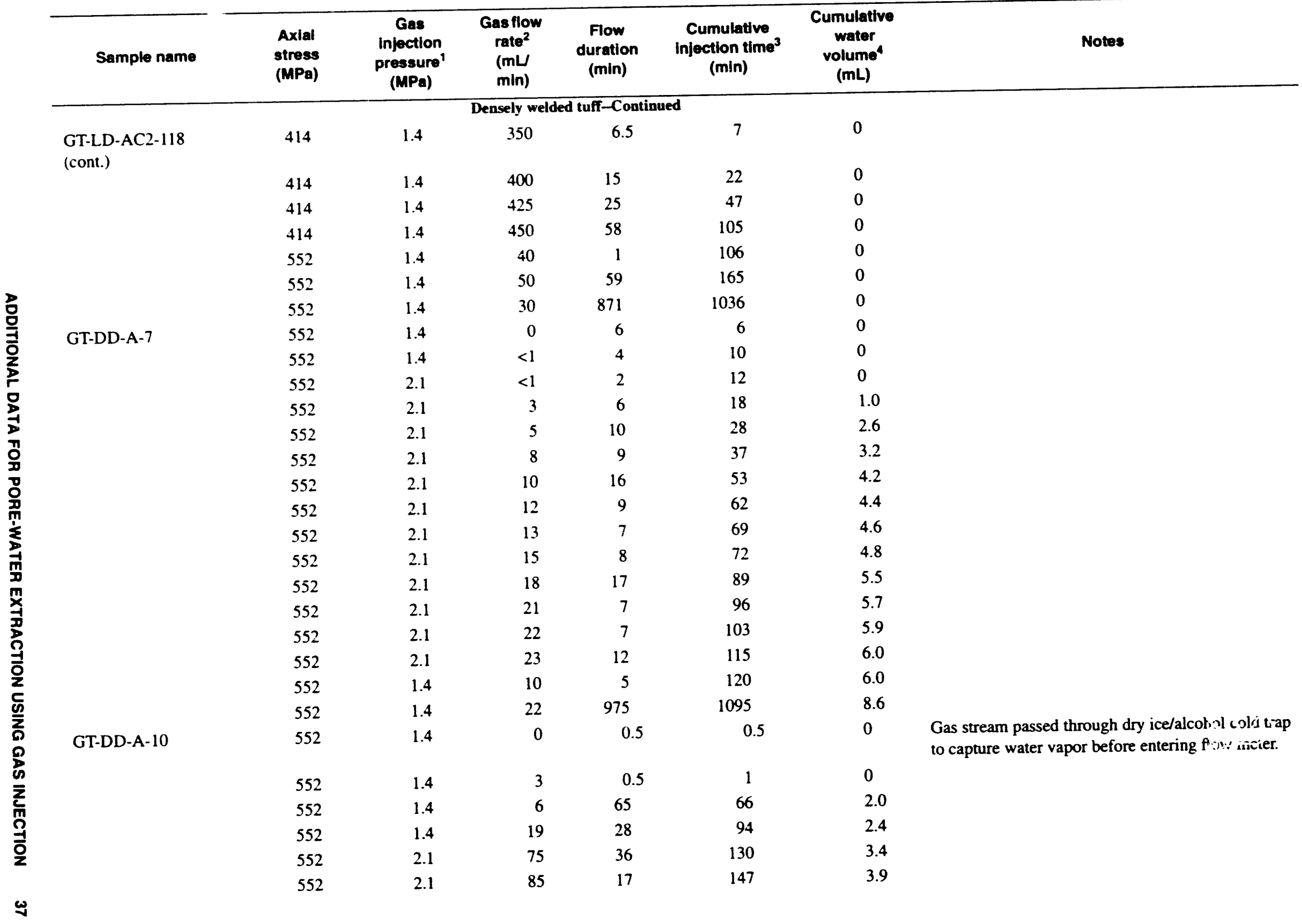


๘ Table 6. Data for one-dimensional compression using gas injection --Continued

\begin{tabular}{|c|c|c|c|c|c|c|c|}
\hline Sample name & $\begin{array}{l}\text { Axial } \\
\text { stress } \\
\text { (MPa) }\end{array}$ & $\begin{array}{c}\text { Gas } \\
\text { injection } \\
\text { pressure' } \\
\text { (MPa) }\end{array}$ & $\begin{array}{c}\text { Gas flow } \\
\text { rate }^{2} \\
(\mathrm{mU} \\
\mathrm{min}) \\
\end{array}$ & $\begin{array}{c}\text { Flow } \\
\text { duration } \\
\text { (min) }\end{array}$ & $\begin{array}{l}\text { Cumulative } \\
\text { injection time } \\
\text { (min) }\end{array}$ & $\begin{array}{l}\text { Cumulative } \\
\text { water } \\
\text { volume } \\
\text { (mL) }\end{array}$ & Notes \\
\hline \multicolumn{8}{|c|}{ Densely welded tuff-Continued } \\
\hline \multirow{4}{*}{ GT-DD-A-10 (cont.) } & 552 & 2.1 & 90 & 10 & 157 & 4.3 & \\
\hline & 552 & 2.1 & 93 & 6 & 163 & 4.4 & \\
\hline & 552 & 4.1 & 325 & 62 & 225 & 5.9 & \\
\hline & 552 & 4.1 & 450 & 4 & 229 & 6.0 & \\
\hline
\end{tabular}

${ }^{\prime}$ Gas injection pressure measured at regulator on gas tank before entry into top of one-dimensional compression cell. Accuracy of measurement is $\pm 0.3 \mathrm{MPa}$.

(is

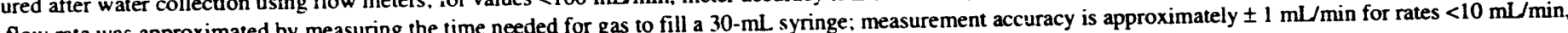
enclosed in parentheses (). flow rate was approximated by measuring the time needed for gas fos fow rate value represents rate at the end of the indicated flow duration.

$\pm 5 \mathrm{~mL} / \mathrm{min}$ for rates between 10 and $50 \mathrm{~mL} / \mathrm{min}$, and $\pm 10 \mathrm{~mL} / \mathrm{min}$.

${ }^{3}$ Cumulative time, in minutes, since the stan of gas injection. measurements of recovered water volume were not made as frequently as measurements of gas flow rate. 
the initial hydraulic conductivity (before compression) but also on how the pore structure and fracture system of the core changes during compression. Consequently, for two apparently similar tuff cores, the same applied gas injection pressure may not produce an equivalent rate-of-water expulsion.

The injected gas penetrates the pore system of the core and, given enough time, will flow out of the other end of the core. Because the gas will flow first through regions of highest permeability, not all of the pore water will be displaced from the core when gas begins to flow out of the exit side of the core. As the injected gas flows through the core, the gas may also cause water expulsion by a process termed "gas-flow traction" by Dropek and Levinson (1975). In a partially saturated core, the gaseous phase occupies the center of large pores and any water is located on the sides of pore walls and at the interstices between grains (pore throats). As gas flows through the pore system, the surface friction between the gas and the pore water "drags" the pore water along. The gas pressure also forces water through the pore throats. (Injection of a dry gas into a saturated or partially saturated core may induce evaporation of the pore water. This problem was examined experimentally and is discussed below in "OneDimensional Compression."

\section{Triaxial Compression}

With few exceptions, gas injection successfully produced additional water in pore-water-extraction tests using triaxial compresşion. Of the set of 17 triaxial compression tests, 11 tests used gas injection. (Four tests-UZ5-223, UZ5-330, UZ5-333, and UZN46-8ended prematurely due to confining fluid leakage; two tests-UZ5-334 and UZ13-354 - were done before gas injection was incorporated as part of the test procedure.) Of the 11 triaxial compression tests that used gas injection, nine produced additional water. (Note that sample UZN46-33, the single, successful triaxial compression test of a moderately welded tuff core, is combined with the remaining triaxial compression tests of nonwelded tuff cores in this discussion.) The volume of water produced by gas injection ranged from 4 to $15 \mathrm{~mL}$, and represented 7 to 100 percent of the total volume of pore water recovered. For tests that had successful pore-water expulsion by gas injection, an average of 69 percent of the total water recovered was produced by gas injection. For three tests of tuff cores that had small initial moisture contents (UZ5-246, UZ5-269, and UZN46-33), gas injection was responsible for all of the water recovered.
Two triaxial compression tests did not recover additional water by using gas injection. Sample UZ4-190 was compressed to $152 \mathrm{MPa}$ axial stress and was subjected to gas injection for 50 minutes using a gas pressure of $0.3 \mathrm{MPa}$. The reason that this sample did not produce additional pore water may be that $0.3 \mathrm{MPa}$ was not sufficient pressure to create a sufficiently large gradient in the pore water to result in water expulsion in 50 minutes. Higher gas pressures (up to $9.7 \mathrm{MPa}$ ) were used in subsequent triaxial compression tests to generate larger gradients in the pore water and more rapid water expulsion. Sample UZ5-235 was compressed to $193 \mathrm{MPa}$ axial stress and, also, did not produce additional water by gas injection. Even though the duration of gas injection was short (17 minutes), gas flow rates of greater than $100 \mathrm{~mL} / \mathrm{min}$ were measured at low injection pressures $(2.8 \mathrm{MPa})$. This sample had the smallest initial moisture content (6.8 percent) of any sample tested by triaxial compression. The reason gas injection was unsuccessful may be that the applied stress was not adequate to compress the sample to a critical state of 100 percent saturation.

Increasing the duration of gas injection increased the volume of pore water recovered for triaxial compression tests that used gas injection. The curves illustrating the nine triaxial compression tests that had successful gas injection indicate this general trend (fig. 23); sample UZA-238 is drawn alone on figure 24 as a representative example. Most of the curves in figure 23 indicate a generally linear relation between duration of gas injection and volume of pore water recovered. At some point during gas injection, however, the volume of extracted pore water begins to decrease-less and less pore water is produced per minute of gas injection. This point is located close to the end of gas injection for sample UZA-238 (fig. 24), but occurs early in the gas injection process for samples UZ5-246, UZ5-269, and UZN46-33. (Note that samples UZ5-246, UZ5-269, and UZN46-33 also have two other features in common: (1) they have the smallest initial moisture contents of all the triaxial compression samples that successfully produced water using gas injection, and (2) they did not produce any pore water until gas injection was applied.) Using gas injection with triaxial compression significantly increased porewater recovery in samples with large ( $>12$ percent) initial moisture contents. While gas injection was not as efficient in extracting pore water from samples that had smaller (11-12 percent) initial moisture contents, gas injection did successfully extract water that was not recoverable using triaxial compression alone. Gas injection was not effective in extracting pore water from samples that had initial moisture contents that were less than 11 percent. 


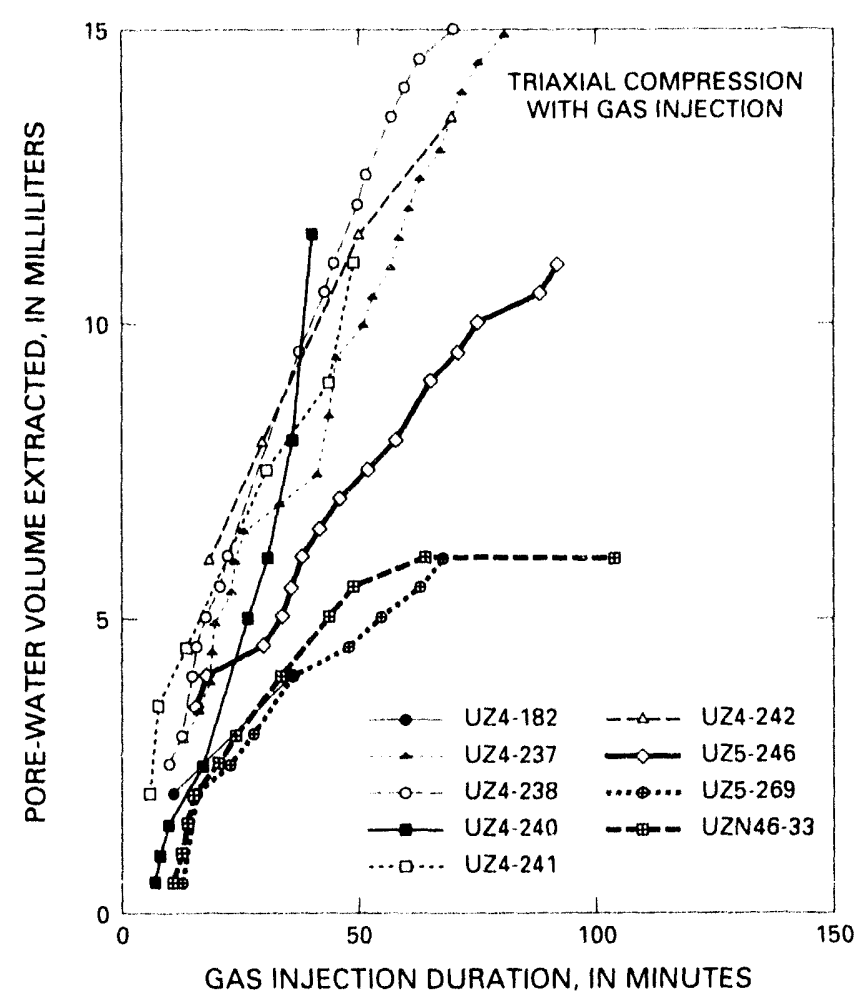

Figure 23. Volume of pore water extracted versus gas injection duration from tuff cores using triaxial compression with gas injection. All cores are nonwelded tuffs except sample $\mathrm{UZN}-33$, which is moderately welded tuff.

\section{One-Dimensional Compression}

Gas injection was used in conjunction with one-dimensional compression on 31 of the 32 onedimensional compression tests. (Gas injection was not attempted during the test of nonwelded tuff sample GT-EX-DH3-2 due to mechanical problems.) The following discussion of the results of gas injection is divided into two parts based on the degree of welding of the test cores.

\section{Nonwelded Tuff}

Gas injection using one-dimensional compression was successful in extracting pore water from nonwelded tuff cores in only a few cases. A description of the trials in which gas injection did not work may help explain why gas injection was successful on only three of the 16 one-dimensional compression tests of nonwelded tuff cores. Gas injection failed on tests UZA-115, UZ5-327, and UZ5-345 due to mechanical problems related to the use of the smooth pair of drainage plates. During these tests, the drainage channels in the top drainage plate became plugged by the Teflon sample wrap. This problem was solved on subsequent tests by using the grooved pair of drainage plates and by ensuring that the Teflon sample wrap did not extend above the top of the core after the core had been inserted into the sample sleeve. The reason the remaining unsuccessful tests did not produce additional pore water may be that the applied gas injection pressure was not sufficient to create a gradient in the pore water that was large enough to result in water expulsion during the short duration of the test. Compression of the pore structure of these nonwelded tuff cores may result in sample permeabilities that are too small to allow expulsion of pore water by gas injection within the time scale of the test.

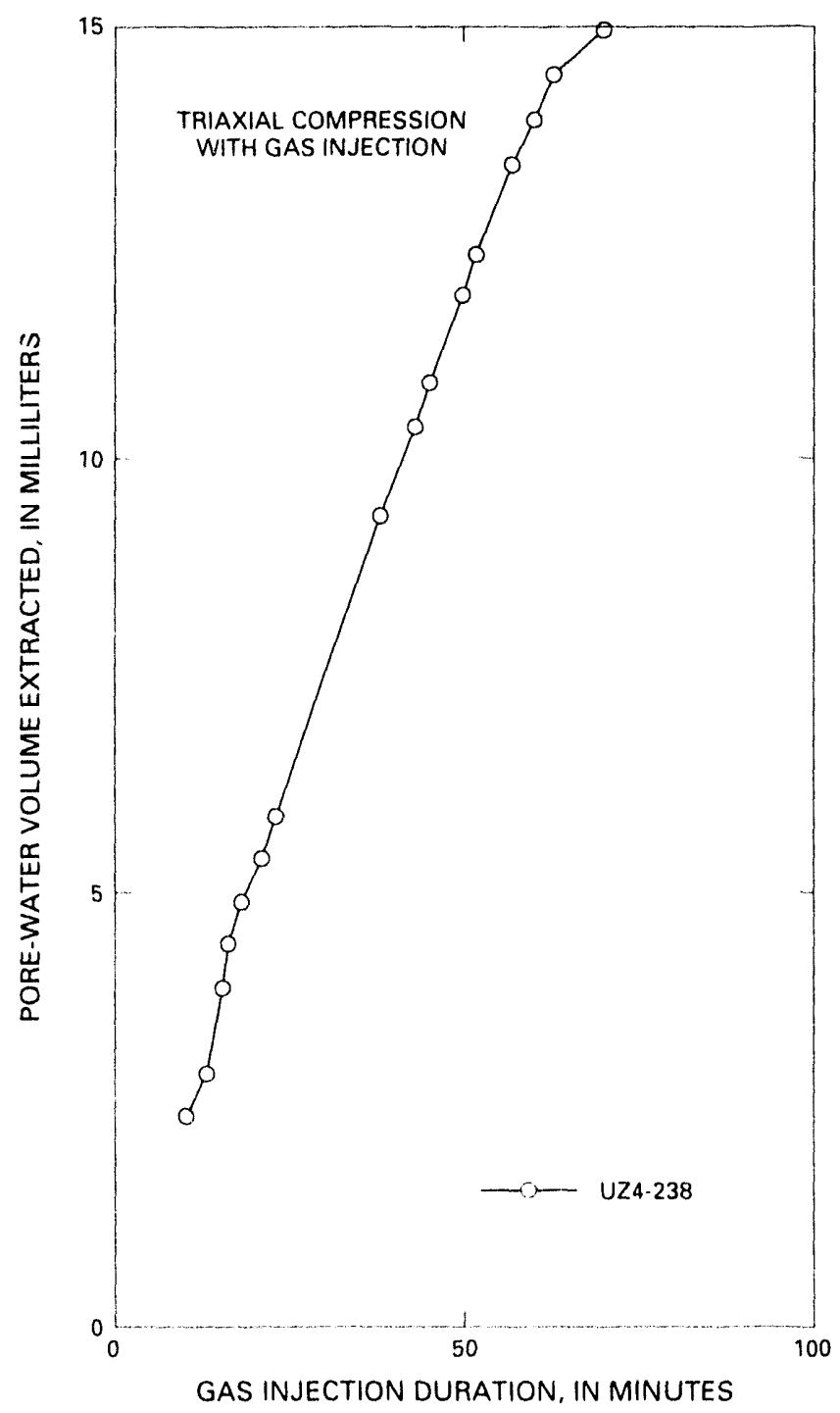

Figure 24. Volume of pore water extracted versus gas injection duration from sample UZ4-238 using triaxial compression with gas injection. 
Pore water was extracted using gas injection on only three of the 16 one-dimensional compression tests of nonwelded tuff cores. These three tests were: UZ5-217, UZ5-230, and GTO-JJ-DB-1A-1-1. Sample UZ5-217 was compressed to a maximum axial stress of $221 \mathrm{MPa}$ and was subjected to $2.8 \mathrm{MPa}$ gas pressure for 4 minutes. Only a trace of water was recovered when the one-dimensional compression cell was disassembled; more water might have been recovered if gas injection had been continued. Sample UZ5-230 was compressed to $434 \mathrm{MPa}$ maximum axial stress and then unloaded (due to operating constraints imposed by the load frame in use) to an axial stress of $351 \mathrm{MPa}$. Gas pressure ranging from 2.8 to $5.5 \mathrm{MPa}$ was applied for a total of 97 minutes; a total of $6 \mathrm{~mL}$ of water was recovered. The success of gas injection on this test may be due to the loading history used, the small (7.6 percent) initial moisture content of the core, or to other factors. Sample GTO-JJ-DB-1A-1-1 recovered water using gas injection only while the core was held at small axial stresses; this test is described in more detail below.

Sample GTO-JJ-DB-1A-1-1 was tested specifically to investigate the relation between applied axial stress and success or failure of gas injection. This sample was loaded using the same loading history as for most other one-dimensional compression tests of nonwelded tuff cores (refer to fig. 17). However, at each stress level, gas injection was attempted to determine if pore water could be extracted. The data for this test are summarized in table 7.

Table 7. Gas injection data for test GTO-JJ-DB-1A-1-1

[MPa, megapascals; min, minutes; $\mathrm{mL}$, milliliters; $\mathrm{mL} / \mathrm{min}$, milliliters per minute]

\begin{tabular}{rcccc}
\hline $\begin{array}{c}\text { Axial } \\
\text { stress } \\
\text { (MPa) }\end{array}$ & $\begin{array}{c}\text { Maximum } \\
\text { gas } \\
\text { injection } \\
\text { pressure } \\
\text { (MPa) }\end{array}$ & $\begin{array}{c}\text { Injection } \\
\text { duration } \\
(\mathrm{min})\end{array}$ & $\begin{array}{c}\text { Pore- } \\
\text { water } \\
\text { volume } \\
\text { extracted } \\
(\mathbf{m L})\end{array}$ & $\begin{array}{c}\text { Pore- } \\
\text { water } \\
\text { extraction } \\
\text { rate' } \\
(\mathrm{mL} / \mathrm{min})\end{array}$ \\
\hline 69 & 1.4 & 17 & 1.9 & 0.11 \\
138 & 4.1 & 38 & 1.2 & 0.032 \\
207 & 7.6 & 66 & 1.8 & 0.027 \\
276 & 7.6 & 47 & 0 & 0 \\
552 & 7.6 & 711 & 0 & 0 \\
\hline
\end{tabular}

\footnotetext{
'Pore-water extraction rate is pore-water volume extracted divided by injection duration.
}

The data from this test indicate that the effectiveness of gas injection decreases as axial stress is increased during tests of nonwelded tuff cores using one-dimensional compression. One-dimensional compression using gas injection was not successful in extracting pore water when the applied axial stress was $276 \mathrm{MPa}$ or greater. In addition, no gas flow through the core was measured at axial stresses greater than or equal to $276 \mathrm{MPa}$. Compaction of the pore system and a decrease in core permeability may be the cause of the decrease in effectiveness of gas injection as axial stress is increased.

\section{Densely Welded Tuff}

Gas injection using one-dimensional compression was most successful in extracting pore water from densely welded tuff cores. All of the 15 onedimensional compression tests of densely welded tuff cores used gas injection; twelve of these tests produced pore water from gas injection. The volume of water produced by gas injection ranged from a trace to $8.6 \mathrm{~mL}$, and represented 100 percent of the total volume of pore water extracted in all but three of the group of 12 tests.

The three tests (of the total 15 tests) that did not recover additional pore water using gas injection (UZ13-62, GTG-LD-WB-3-1-1, and GT-LD-AC2118) had the three smallest initial moisture contents of the group of densely welded tuff cores tested using onedimensional compression. These three samples produced no water-either by compression or using gas injection. The reason gas injection was unsuccessful for these three tests may be that the applied stress was not adequate to compress the samples to a state of 100 percent saturation. These three tests illustrate the importance of compression to the process of porewater extraction. Unless a core is compressed adequately to produce saturated conditions, injection of an inert gas does not expel pore water. Instead, the gas flows past pore water that is retained on the pore walls by capillary attraction.

Similar to triaxial compression, increasing the duration of gas injection increased the volume of pore water recovered for one-dimensional compression tests that used gas injection. Data for ten tests of densely welded tuff cores using one-dimensional compression are illustrated in figure 25. Data from tests GT-LDAC2-17 and GT-LD-AC2-18 are not plotted because these two tests had very small volumes of water recovered; data for one nonwelded tuff test (UZ5-230) are also included on figure 25 (to display the entire data set). Sample GT-LD-AC2-62 is drawn alone on figure 26 as a representative example of a onedimensional compression test of a densely welded tuff core using gas injection. Most of the curves in figure 25 indicate a generally linear relation between the duration of gas injection and the volume of pore water recovered. 


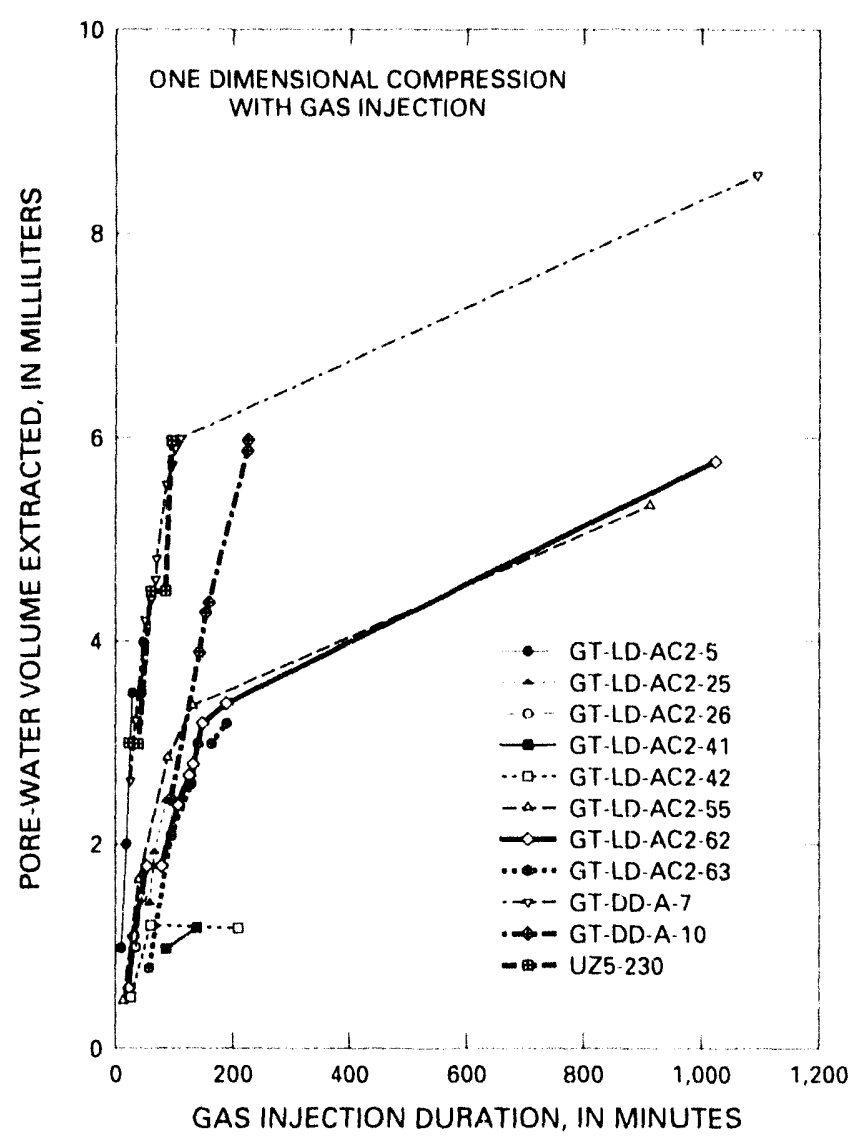

Figure 25. Volume of pore water extracted versus gas injection duration from tuff cores using one-dimensional compression with gas injection. All cores are densely welded tuffs except sample UZ5-230 which is nonwelded tuff.

Like triaxial compression, at some point during gas injection, the volume of extracted pore water begins to decrease-less and less pore water is produced per minute of gas injection. This relation is especially noticeable in tests with long duration gas injection (GT-LD-AC2-55, GT-LD-AC2-62, and GT-DD-A-7). Gas injection was responsible for nearly all the water recovered from one-dimensional compression tests of densely welded tuff cores that had initial moisture contents greater than 6.5 percent or initial saturations greater than 64 percent. Experience from tests of densely welded tuff cores using one-dimensional compression and gas injection indicated that if no water had been recovered after 60 minutes, continued gas injection was unlikely to produce any pore water.

The volume of water recovered from onedimensional compression tests using long duration gas injection may be affected by the evaporation of pore water into the injection gas. The potential for evaporation of pore water caused by the injection of dry gas

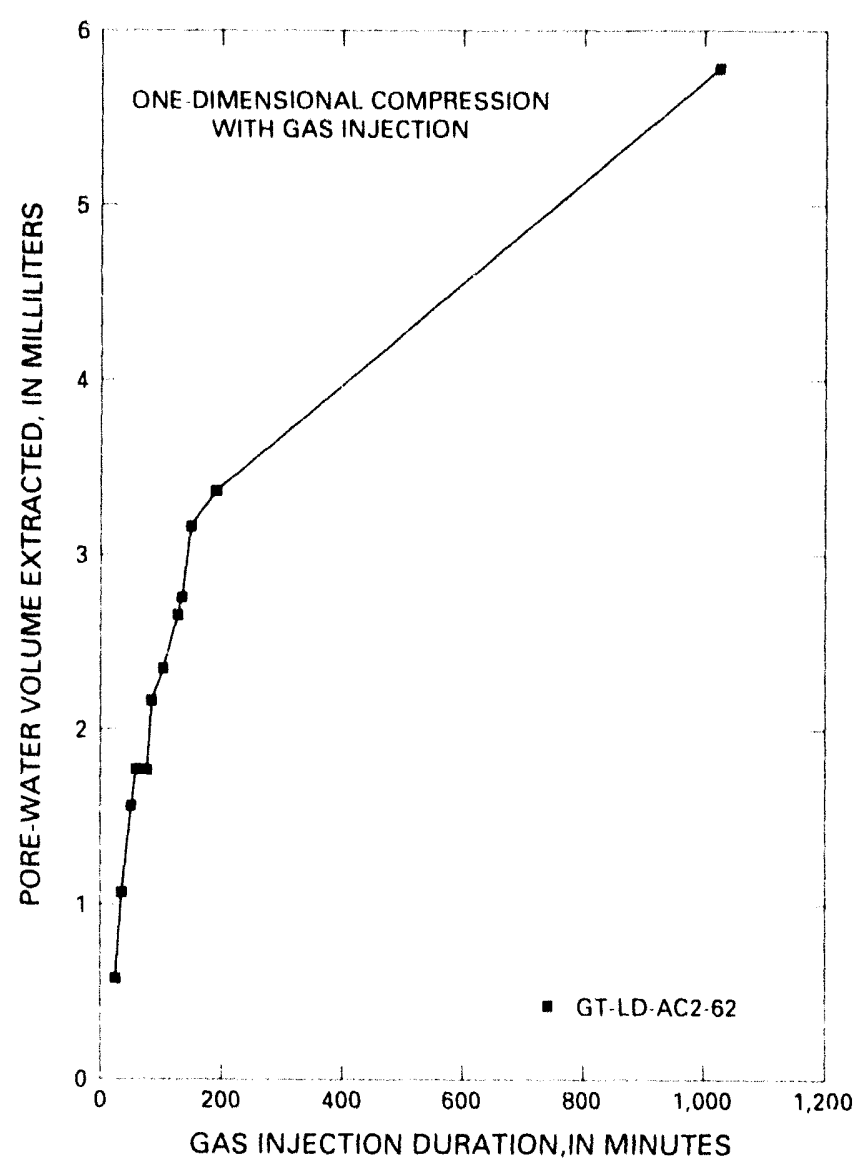

Figure 26. Volume of pore water extracted versus gas injection duration from sample GT-LD-AC2-62 using onedimensional compression with gas injection.

was investigated during the test of sample GT-DDA-10. A cold trap cooled to about $-78^{\circ} \mathrm{C}$ by a dry iceisopropyl alcohol slurry was inserted into the water collection system between the collection syringe and the gas flow meter. Any water vapor that passed the collection syringe was collected in the cold trap. The results of this investigation are detailed in table 8 and figure 27.

The volume of pore water evaporated (and collected in the cold trap) increased greatly between 5.6 and 22 liters of gas injected. The $0.4-\mathrm{mL}$ volume of water collected in the cold trap would represent about 7 percent of the total $6.0 \mathrm{~mL}$ of water collected using one-dimensional compression and gas injection for sample GT-DD-A-10. Evaporation of pore water would increase the concentrations of all the dissolved ions in the pore water; compression tests that use gas injection for long durations and/or large gas flow rates may exhibit increased ion concentrations in pore water 
recovered after large volumes of injected gas have passed through the core.

Table 8. Gas injection data for test GT-DD-A-10

[MPa, megapascals; $\mathrm{mL}$, milliliters]

\begin{tabular}{ccc}
\hline $\begin{array}{c}\text { Maximum gas } \\
\text { Injection } \\
\text { prossure } \\
\text { (MPa) }\end{array}$ & $\begin{array}{c}\text { Gas volume } \\
\text { Injocted } \\
\text { (Ilters) }\end{array}$ & $\begin{array}{c}\text { Water volume } \\
\text { recovored In } \\
\text { cold trap } \\
\text { (mL) }\end{array}$ \\
\hline 1.4 & 0.9 & 0 \\
2.1 & 5.6 & 0.02 \\
4.1 & 22 & 0.4 \\
\hline
\end{tabular}

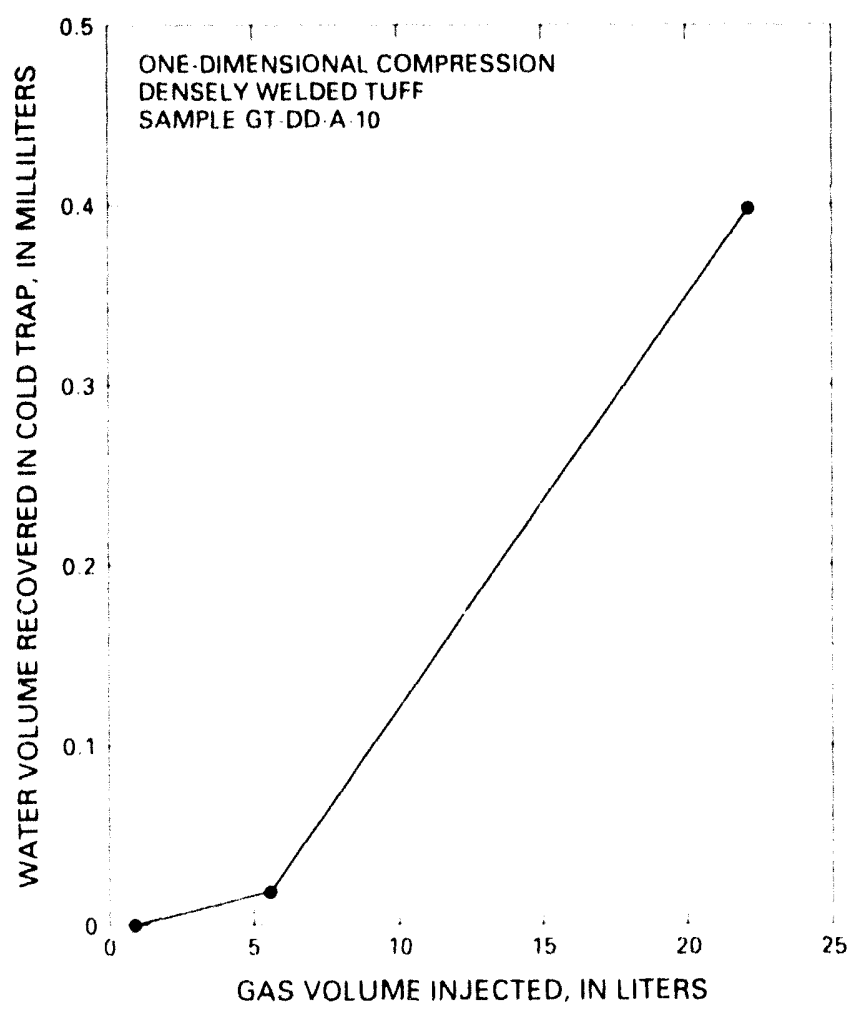

Figure 27. Volume of pore water collected by cold trap versus gas volume injected from sample GT-DD-A-10 during one-dimensional compression with gas injection.

\section{Gas Injection Summary}

Pore-water extraction from nonwelded tuff cores using gas injection in conjunction with either triaxial or one-dimensional compression was not successful at axial stresses greater than $276 \mathrm{MPa}$. (Sample UZ5-230 is the only exception to this ctatement from the group of 49 tests done for this study.) Compression of the pore system and a decrease in core permeability may be the cause of the decrease in effectiveness of gas injection as axial stress is increased. At axial stresses less than $276 \mathrm{MPa}$, gas injection was successful in expelling pore water from nonwelded tuff cores provided that: (1) the applied gas pressure was at least 1.4 MPa, and (2) the test core was compressed enough to fully saturate the pore system.

Gas injection was responsible for most of the water recovered from densely welded tuff cores during one-dimensional compression tests. For nine of the 12 one-dimensional compression tests that produced water using gas injection, all of the expelled water was recovered during gas injection. Gas injection successfully expelled pore water from densely welded tuff cores compressed at the maximum axial stress (552 MPa) provided the test core was compressed adequately to fully salturate the pore system.

Data from all of the compression tests that used gas injection indicate that increasing the duration of gas injection increased the volume of pore water expelled. The usual pattern of water expulsion included an initial period during which the volume of water extracted was roughly proportional to the duration of gas injection; afterwards, the volume of water expelled per minute of injection steadily decreased. The maximum duration of gas injection also is limited by the potential for evaporation of the pore water into the injected gas. One one-dimensional compression test of a densely welded tuff core indicated that evaporation may be a concern when the volume of injection gas exceeds about 6 liters, and that evaporation of pore water should be considered likely when the volume of injected gas is greater than about 20 liters.

Data collected from pore-water-extraction tests using triaxial compression and gas injection indicate that gas injection at a pressure of at least 1.4 MPa for at least 60 minutes is necessary for maximum water recovery from nonwelded tuff cores (provided axial stress is less than $276 \mathrm{MPa}$ ). For one-dimensional compression of densely welded tuff cores using gas injection, an injection pressure of at least 1.4 MPa for at least 180 minutes is needed for maximum water extraction.

\section{ADDITIONAL DATA FOR COMPRESSION}

\section{Tuff Mineralogy}

Determination of the mineralogical composition of tuff cores was done to characterize the rocks being compressed and will be used in the second phase of 
this study to aid in the interpretation of the dissolved ionic chemistry of extracted pore water. Samples of seven tuff cores that had been compressed using onedimensional compression were analyzed for quantitative mineralogical composition. The group of seven samples was selected based on two criteria: (1) availability of detailed pore-water chemistry analyses, and (2) applicability of the mineralogical results to the largest number of similar tuff cores. Samples were also chosen to provide a minimal check of analysis repeatability. Samples for mineralogical analysis (about 10 to $20 \mathrm{~g}$ ) were taken from the compressed cores or from the cut end pieces created during core preparation. Analyses were done by Crystal Research Laboratories, in Lander, Wyoming.

Whole-rock chemical analyses of the set of seven samples are listed in table 9. Analyses were done using standard methods of X-ray fluorescence (XRF) analysis (Jones, 1987). Data in table 9 are separated according to degree of welding and lithologic unit. For comparison, table 9 also includes two entries that represent averages of XRF analyses made by other investigators on samples from the same formations (Connolly and others, 1983; 1984). Analyses of samples from Tunnel bed 5 and from the Grouse Canyon Member indicate good internal consistency and agreement with other published analyses; the analyses of samples from the Topopah Spring Member display more variation.

Crystal Research Laboratories used the Quantitative Mineral Analysis System (QMAS) analysis program (Slaughter, 1990) to determine individual mineral components from the results of the XRF analyses.

$\mathrm{X}$-ray diffraction analysis and optical petrography supplemented XRF analysis in the determination of mineralogical composition. The mineralogical composition of the set of seven tuff samples is listed by weight in table 10 and by volume in table 11 . The zeolite mineral clinoptilolite was the most frequently occurring mineral in all of the nonwelded tuff samples; the clinoptilolite content of the five nonwelded tuff samples ranged from 53 to 76 percent. Clay minerals including illite, ferric illite (similar, but not identical to nontronite), montmorillonite, and chlorite were also found in the five nonwelded tuff samples; the total clay mineral content in these samples ranged from 3 to 30 percent. The presence of zeolite and clay minerals may be due to the hydration of original, unstable tuff components in the presence of ground water (White and others, 1980). Two feldspars, sanidine and albite, and quartz together composed about 90 percent of each of the two densely welded tuff samples. These two samples each contained about 10 percent clay minerals and almost no zeolites.
The cation exchange capacity of six of the seven samples also was analyzed by Crystal Research Laboratories (table 12). A standard wet-chemistry method utilizing ammonium $\left(\mathrm{NH}_{4}{ }^{+}\right)$ions to displace cations in the sample was used (Lieu and others, 1988). Zeolite minerals are known to have large cation exchange capacities (Hay, 1966; Sherry, 1971). The highly zeolitic nonwelded tuff samples have large cation exchange capacities; the densely welded tuff samples have small zeolite contents, and correspondingly small cation exchange capacities.

\section{Tuff Pore-Size Distribution}

Determination of the pore-size distribution of tuff cores was done to aid in the interpretation of the mechanisms involved in pore-space collapse during compression. Two subsamples were collected from each of four cores that had been compressed using one-dimensional compression. The four cores were: UZ5-335, GTO-JJ-DB-1A-2-1, GT-LD-AC2-55, and GT-LD-AC2-62. These four test cores were selected from the group of cores chosen for quantitative mineralogical analysis so that correlations between pore-size distribution and mineralogy would be possible. The four cores also were chosen to evenly divide the analyses between nonwelded and densely welded tuff cores. The two subsamples were collected from each test core to represent the core pore-size distribution before and after compression. The before-compression subsample (indicated by the suffix "-BC" added to the sample name) was collected from the cut end pieces created during preparation of the test core for compression. The after-compression subsample (indicated by the suffix "-AC" added to the sample name) was taken from the test core after the completion of compression testing.

Intact tuff fragments measuring about $25 \mathrm{~mm} \times$ $13 \mathrm{~mm} \times 13 \mathrm{~mm}$ were used for pore-size distribution analysis. The before-compression fragments were collected by breaking the core end pieces to create fragments of the correct size. After compression, test cores (especially the densely welded tuff cores) often were fractured and fragment selection was usually only a matter of choosing appropriately sized pieces from the compressed core samples. (Note that this small sample size probably represents intact rock with no regard to large scale fractures that may be present in the core.) Pore-size distributions were determined by Surtek, Inc., in Golden, Colorado, using mercury injection porosimetry. 
Table 9. Whole-rock chemical analyses of tufts'

[Content in percent by weight: <. less than: $\cdots$, not analyzed]

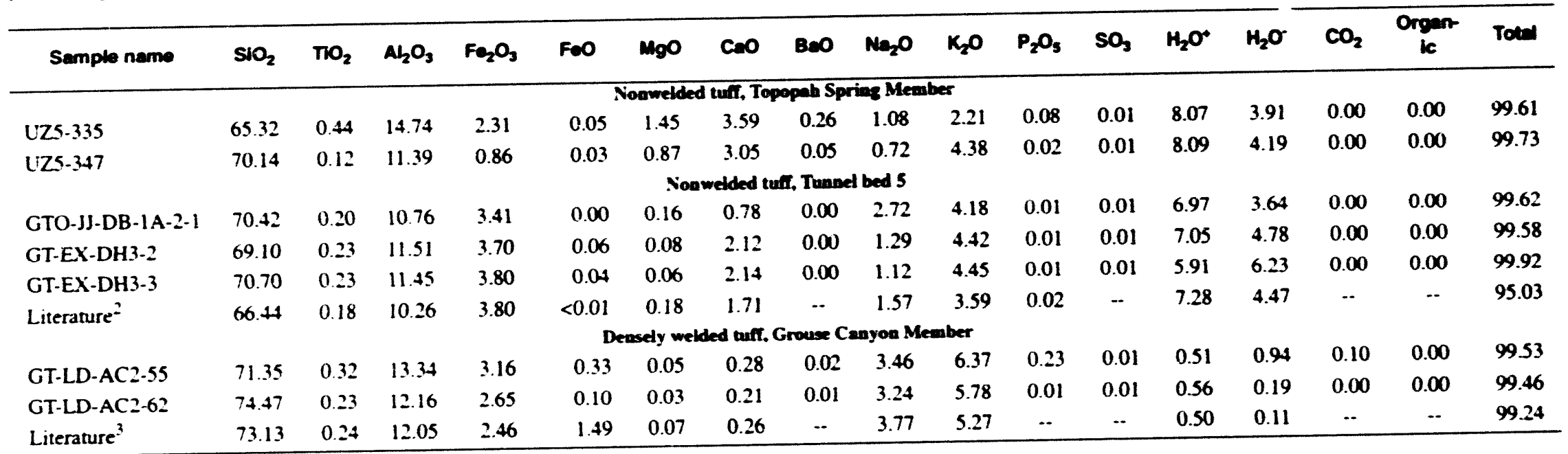

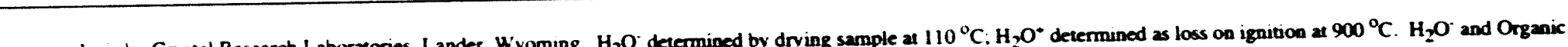

${ }^{1} \mathrm{X}$-ras fluoresence analysis by $\mathrm{C}$ ystal Research Laboratories. Lander. Wyoming. $\mathrm{H}_{2} \mathrm{O}^{-}$determined by drying sample at $110^{\circ} \mathrm{C}$ : $\mathrm{H}_{2} \mathrm{O}^{*}$ determined as loss on ignition at 900 are not included in the totals.

Average of 14 samples from Connolly and ochers. 1984

Average of four samples from Connolly and ochers. 1983. 
Table 10. Mineralogical composition of tuffis by weight ${ }^{1}$

[Mineral content in percent by weight: -- not found]

\begin{tabular}{|c|c|c|c|c|c|c|c|c|c|c|c|c|c|c|c|}
\hline Sample name & $\begin{array}{l}\text { Sant- } \\
\text { dine }\end{array}$ & Albite & Ouartz & $\begin{array}{l}\text { Cristo } \\
\text { bellte }\end{array}$ & $\begin{array}{l}\text { Amor- } \\
\text { phous } \\
\text { sllica }\end{array}$ & $\begin{array}{l}\text { Clln- } \\
\text { optil- } \\
\text { loits }\end{array}$ & $\begin{array}{l}\text { Forric } \\
\text { ithe }\end{array}$ & $\begin{array}{l}\text { milted } \\
\text { mont- } \\
\text { morlt- } \\
\text { lonito }\end{array}$ & $\begin{array}{c}\text { Chlor- } \\
\text { ne }\end{array}$ & Pyrthe & Rutlle & Coottine & Calctio & Blothe & Toted \\
\hline \multicolumn{16}{|c|}{ Nonwelded tuff, Topopab Spring Member } \\
\hline UZ5-335 & 2.01 & 2.38 & 3.15 & -- & 9.66 & 52.78 & 6.60 & 21.14 & 1.80 & $\mathbf{0}$ & 0.43 & -- & -. & - & 99.95 \\
\hline UZ5-347 & 6.26 & -. & 0.42 & 10.94 & .. & 76.07 & 2.56 & -. & 0.19 & 0 & -- & -- & -- & 3.42 & 99.86 \\
\hline GTO-JJ-DB-1A-2-1 & 9.63 & \multicolumn{14}{|c|}{ Nonwelded tuff, Tunnel bed 5} \\
\hline GT-EX-DH3-2 & 14.44 & $\begin{array}{l}.- \\
.-\end{array}$ & 3.46 & .. & -- & 75.75 & 10.56 & -- & 0.11 & 0 & 0.19 & 0.10 & -. & - & $\begin{array}{l}99.80 \\
0091\end{array}$ \\
\hline GT-EX-DH3-3 & 13.61 & $\begin{array}{l}-. \\
--\end{array}$ & 0.57 & -. & 11.09 & 61.00 & 11.92 & - & 0.57 & $\begin{array}{l}0.01 \\
0.01\end{array}$ & $\begin{array}{l}0.22 \\
0.22\end{array}$ & $\begin{array}{l}0.09 \\
0.08\end{array}$ & $\begin{array}{l}-. \\
.-\end{array}$ & - & $\begin{array}{l}99.91 \\
99.95\end{array}$ \\
\hline \multicolumn{16}{|c|}{ Densely welded tuff, Grouse Canyon Member } \\
\hline GT-LD-AC2-55 & 51.75 & 13.34 & 22.86 & -- & -. & -- & 10.56 & 0.55 & 0.17 & 0 & 0.33 & -- & 0.20 & - & 99.76 \\
\hline GT-LD-AC2-62 & 43.84 & 14.23 & 31.49 & -- & .. & 1.04 & 9.13 & .. & .. & 0 & 0.23 & -- & $-\cdot$ & - & 99.97 \\
\hline
\end{tabular}

'Mineralogical analysis by Crystal Research Laboratories. Lander. Wyoming using X-ray diffraction. X-ray fuoresence. optical petrography. and Quantitative Mineral Analysis System (QMAS) analysis program (Slaughter. 1990). 
Table 11. Mineralogical composition of tuft's by volume'

[Mineral content in percent by volume: $\cdots$, not found]

\begin{tabular}{|c|c|c|c|c|c|c|c|c|c|c|c|c|c|c|c|}
\hline Sample name & $\begin{array}{l}\text { Sani- } \\
\text { dine }\end{array}$ & Albite & Quartz & $\begin{array}{l}\text { Cristo } \\
\text { balite }\end{array}$ & $\begin{array}{l}\text { Amor- } \\
\text { phous } \\
\text { sllica }\end{array}$ & $\begin{array}{l}\text { Clin- } \\
\text { optst- } \\
\text { lolte }\end{array}$ & $\begin{array}{l}\text { Forric } \\
\text { Hilite }\end{array}$ & $\begin{array}{l}\text { Inthd } \\
\text { mont- } \\
\text { morlt- } \\
\text { lonite }\end{array}$ & $\begin{array}{c}\text { Chlor- } \\
\text { ite }\end{array}$ & Pyrite & Rutlle & Goothite & Calcite & Biodte & Total \\
\hline \multicolumn{16}{|c|}{ Nonwelded tuff, Topopah Spring Member } \\
\hline UZ5-335 & 1.81 & 2.08 & 2.74 & -- & 8.40 & 56.59 & 5.85 & 20.73 & 1.50 & 0 & 0.24 & - & $\cdot-$ & -- & 99.95 \\
\hline UZ5-347 & 5.47 & -- & 0.35 & 10.44 & -- & 78.72 & 2.19 & - & 0.15 & 0 & -- & - & - & 2.53 & 99.86 \\
\hline \multicolumn{16}{|c|}{ Nonwelded tuff, Tunnel bed 5} \\
\hline GTO-JJ-DB-IA-2-1 & 8.47 & - & 2.93 & -- & -- & 79.05 & 9.11 & - & 0.09 & 0 & 0.10 & 0.05 & -- & -- & 99.80 \\
\hline GT-EX-DH3-2 & 12.92 & -- & 0.49 & -- & 9.55 & 64.73 & 11.57 & - & 0.49 & 0 & 0.12 & 0.05 & $-\cdot$ & .- & 99.91 \\
\hline GT-EX-DH3-3 & 12.23 & - & 0.45 & -- & 12.04 & 62.64 & 11.89 & $-\cdot$ & 0.54 & 0 & 0.12 & 0.04 & $-\cdot$ & $\cdots$ & 99.95 \\
\hline \multicolumn{16}{|c|}{ Densely welded turf. Grouse Canyon Member } \\
\hline GT-LD-AC2-55 & 52.59 & 13.15 & 22.35 & -. & $-\cdot$ & .. & 10.53 & 0.61 & 0.16 & 0 & 0.20 & - & 0.19 & -- & 99.76 \\
\hline GT-LD-AC2-62 & 44.59 & 14.03 & 30.82 & -. & - & 1.25 & 8.97 & - & - & 0 & 0.14 & - & -- & - & 99.97 \\
\hline
\end{tabular}

'Mineralogical analysis by Crystal Research Laboratories, Lander, Wyoming using X-ray diffraction. X-ray fluoresence, optical petrography, and Quantitative Mineral Analysis System (QMAS) analysis program (Slaughter. 1990). 
Table 12. Cation exchange capacity data for tuffs

(Analysis by Crystal Research Laboratories, Lander, Wyoming; -., not analyzed]

\begin{tabular}{cc}
\hline Sample name & $\begin{array}{c}\text { Cation exchange capacity } \\
\text { (milliequivalents per 100 g) }\end{array}$ \\
\hline Nonwelded tuff, Topopah Spring Member \\
UZ5-335 & 91.4 \\
UZ5-374 & - \\
Nonwelded tuff, Tunnel bed 5 & \\
GTO-JJ-DB-1A-2-1 & 187.0 \\
GT-EX-DH3-2 & 163.5 \\
GT-EX-DH3-3 & 175.6 \\
Densely welded tuff, Grouse Canyon Member \\
GT-LD-AC2-55 \\
GT-LD-AC2-62 \\
\hline
\end{tabular}

Injection of mercury at various pressures into the air-filled pore space of a rock sample can be used to determine the relation between the applied mercury pressure and the volume of mercury that enters the pore space; this relation is commonly termed a capillary pressure curve (Purcell, 1949). The applied mercury pressure, or capillary pressure, is related to the size of the pore into which the mercury is injected by the following empirical equation (Dake, 1978):

$$
P_{c}=\frac{2 \sigma \cos \Theta}{r}
$$

where:

$$
\begin{aligned}
P_{c}= & \text { capillary pressure } \\
\sigma= & \text { interfacial tension (between mercury and } \\
& \text { air) } \\
\Theta= & \text { contact angle of the wetting fluid (between } \\
& \text { mercury and rock) } \\
r= & \text { capillary radius }
\end{aligned}
$$

The terms $\sigma$ and $\Theta$ are constants for a particular system; for the mercury-air-rock system $\sigma$ is about 480 dyne $/ \mathrm{cm}$ and $\Theta$ is about $140^{\circ}$ (Monicard, 1980). Surtek, Inc., used these values to calculate the capillary radius, $r$, from the measured values of the applied pressure, $P_{c}$. Mercury porosimetry data collected by Surtek, Inc., for the set of eight samples are listed in table 18 under "Supplemental Information."

Capillary pressure curves for the set of eight samples are presented in figures 38 through 41 under "Supplemental Information" (note that only the drainage segment, the portion of the data in which the capillary pressure is increasing, is plotted on these figures). Curves representing the before-compression sample and the after-compression sample for each test core are plotted together on the same graph to illustrate the change in mercury injection characteristics caused by one-dimensional compression. Only small changes are present in the shapes of the capillary pressure curves for the welded tuff samples; large differences are evident between the before-compression curves and the after-compression curves for the nonwelded tuff samples.

The capillary pressure data in table B-1 also can be used to determine the pore-size distribution of a sample. If it is assumed that mercury fills all the pores at the maximum capillary pressure, a pore-size frequency histogram can be constructed for each sample. (This statement assumes that the sample contains no pores smaller than $0.05 \mu \mathrm{m}$ and that all the pores are connected. While mercury injection at pressures greater than $13.8 \mathrm{MPa}$ would be required to assess the first assumption, the degree of pore interconnectivity was studied by Manger (1965). In ten samples of nonwelded tuff from the NTS, Manger found that the total amount of occluded (nonconnected) porosity was less than 0.1 percent.) Frequency histograms illustrating the distribution of pore sizes, both before and after compression, are presented in figures 28-31 for the four pairs of samples analyzed using mercury porosimetry.

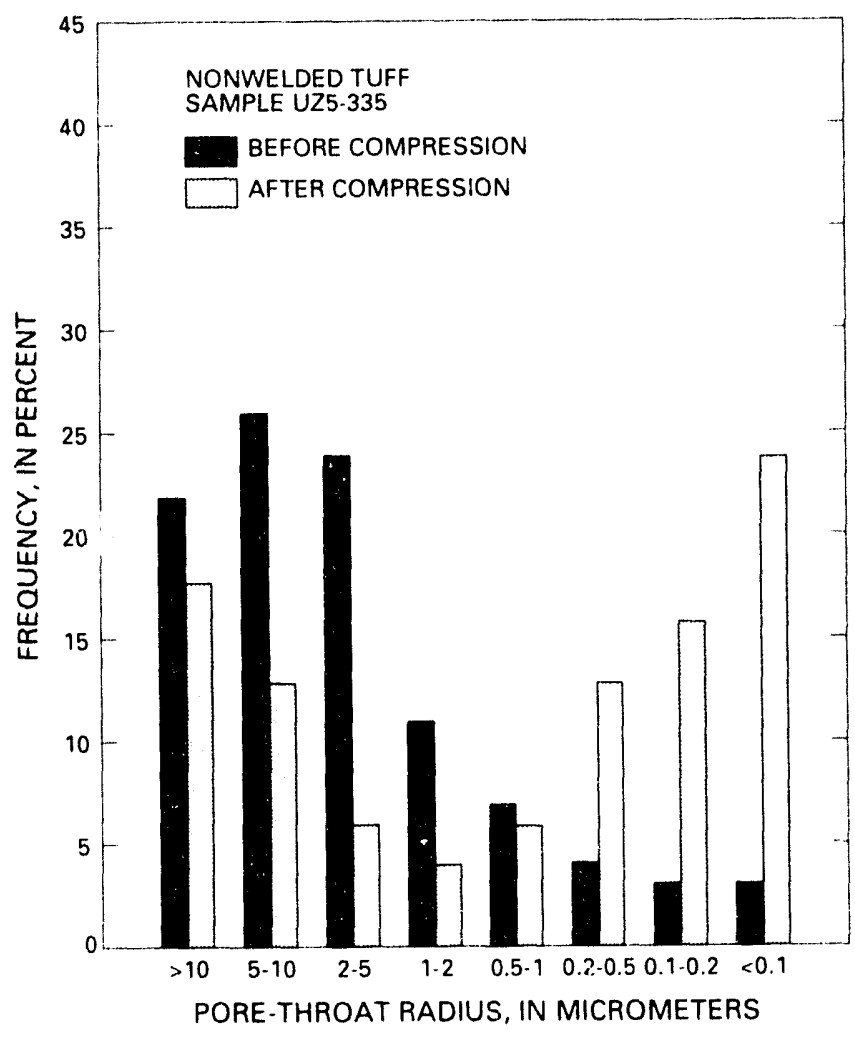

Figure 28. Pore-size distribution for sample UZ5-335. 


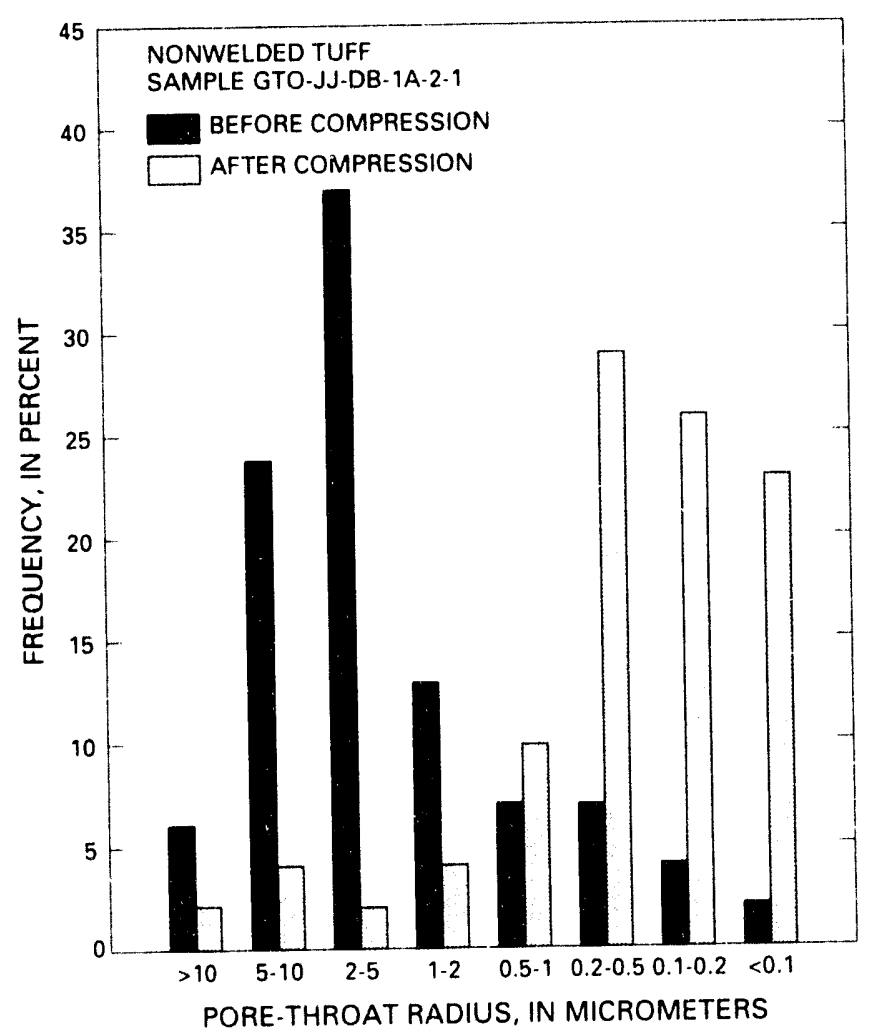

Figure 29. Pore-size distribution for sample GTO-JJ-DB1A-2-1.

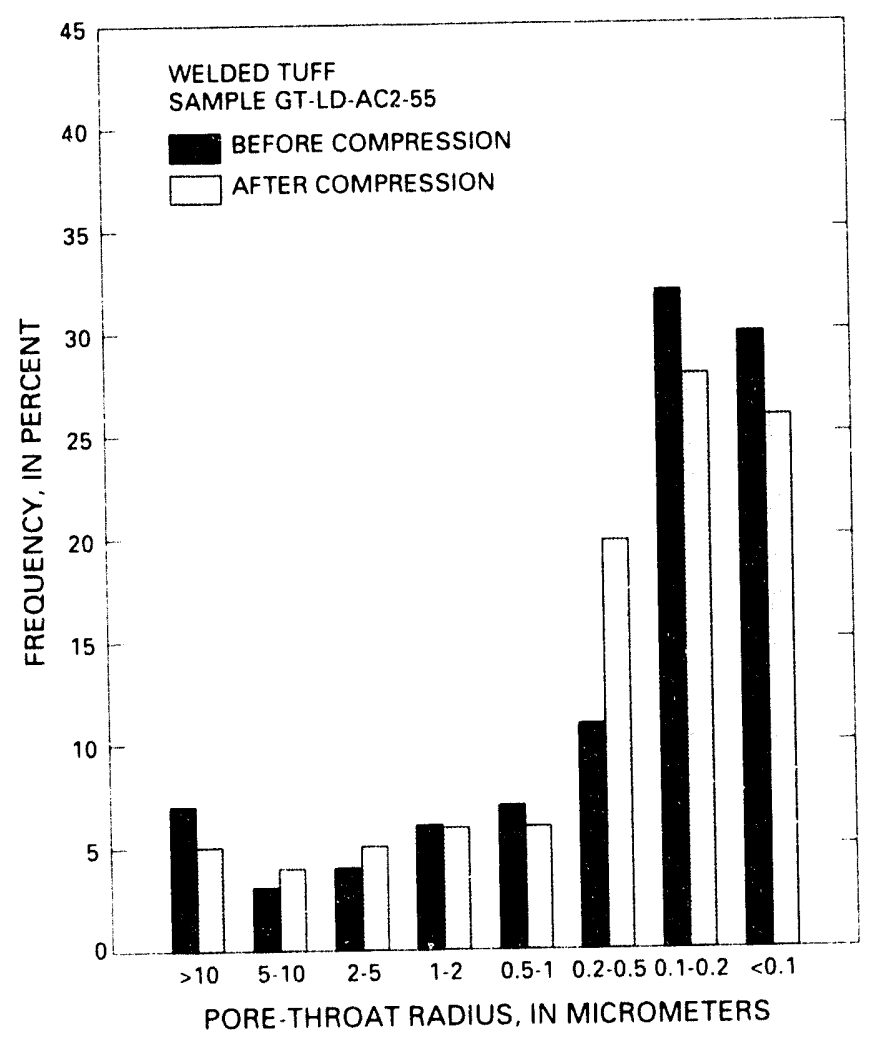

Figure 30. Pore-size distribution for sample GT-LD-AC2-55.

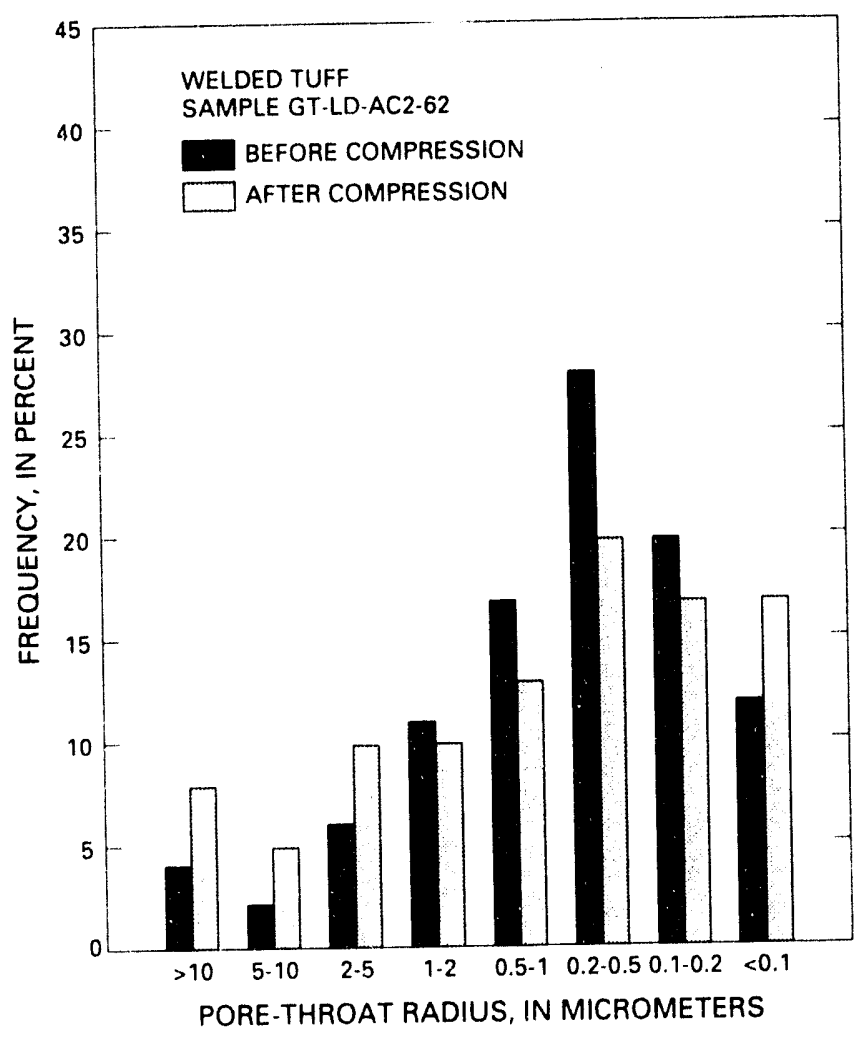

Figure 31. Pore-size distribution for sample GT-LD-AC2-62.

A summary of the pore-size distribution data is listed in table 13. Both nonwelded tuff samples had large percentages of large $(>2 \mu \mathrm{m})$ pores and small percentages of small $(<0.5 \mu \mathrm{m})$ pores before compression; however, after compression to $552 \mathrm{MPa}$ using onedimensional compression, both samples indicated a large decrease in the number of large pores and a large increase in the number of small pores. The simple conclusion from this observation is that, during onedimensional compression of nonwelded tuff cores, large pores are reduced in size as the total pore volume of the core is decreased.

Densely welded tuff sample GT-LD-AC2-55 displayed very little change in pore-size distribution between the before- and after-compression samples. Densely welded tuff sample GT-LD-AC2-62 exhibited more variation. Although the two densely welded tuff samples had similar pore-size distributions before compression, sample GT-LD-AC2-62 indicated an increase in large pores and a slight decrease in small pores after compression. This change in the pore-size distribution for sample GT-LD-AC2-62 may be real or may be caused by sample selection. Densely welded tuff samples used for one-dimensional compression tests occasionally contained small, porous pumice fragments within the densely welded matrix; inclusion of a highly 
porous pumice fragment in a sample used for mercury injection porosimetry could have a large impact on the resultant pore-size distribution. Although visible pumice fragments were avoided during sample selection from densely welded tuff cores, small pumice fragments within the interior of a sample may have been present. Data concerning sample porosity, discussed next, support a change in sample lithology as the explanation for the change in pore-size distribution observed in sample GT-LD-AC2-62.

Table 13. Pore-size distribution data for tuffs

1>, greater than; $\mu \mathrm{m}$, micrometer; <, less than; $\mathrm{BC}$, before compression; AC, after compression']

\begin{tabular}{|c|c|c|c|c|}
\hline \multirow{2}{*}{ Sample name } & \multicolumn{2}{|c|}{$\begin{array}{c}\text { Large pores } \\
\text { (percent }>2 \mu \mathrm{m} \text { ) }\end{array}$} & \multicolumn{2}{|c|}{$\begin{array}{c}\text { Small pores } \\
\text { (percent }<0.5 \mu \mathrm{m} \text { ) }\end{array}$} \\
\hline & BC & $A C$ & $\mathbf{B C}$ & $A C$ \\
\hline \multicolumn{5}{|c|}{ Nonwelded tuff } \\
\hline UZ5-335 & 72 & 37 & 10 & 53 \\
\hline GTO-JJ-DB-1 A-2-1 & 67 & 8 & 13 & 78 \\
\hline \multicolumn{5}{|c|}{ Densely weided tuff } \\
\hline GT-LD-AC2-55 & 14 & 14 & 73 & 74 \\
\hline GT-LD-AC2-62 & 12 & 23 & 60 & 54 \\
\hline
\end{tabular}

'All the samples listed as "after compression" were compressed to
a maximum axial stress of $552 \mathrm{MPa}$ using one-dimensional compression.

In addition to the capillary pressure measurements, Surtek, Inc. determined the porosity of each of the eight samples. Values of the grain volume of the samples were measured using an air comparison pycnometer (Beckman model 930). Data from the air pycnometer can be used in Boyle's Law $\left(P_{1} V_{1}=P_{2} V_{2}\right)$ to determine grain volume. Grain volume and the total sample volume (acquired during the capillary pressure measurements) were then used to calculate the sample porosity:

$$
n=\frac{V_{T}-V_{G}}{V_{G}}
$$

where:

$$
\begin{aligned}
& n=\text { porosity } \\
& V_{T}=\text { total volume } \\
& V_{G}=\text { grain volume }
\end{aligned}
$$

Porosity data for the set of eight samples are listed in table 14. Changes in sample porosity indicate similar relations between before- and aftercompression samples as were determined from the capillary pressure measurements. Both nonwelded tuff samples indicated a decrease in porosity from before compression to after compression. Densely welded tuff sample GT-LD-AC2-55 displayed little change in porosity due to compression. Porosity data for sample GT-LD-AC2-62 indicated a large increase in sample porosity from before-to-after compression. It is possible that the after-compression subsamples collected from the two densely welded tuff cores contained microfractures created by compression. However, the inclusion of fractures would not contribute significantly to the total sample porosity (Schlumberger, 1987). The apparent increase in the porosity of sample GT-LD-AC2-62 may be due to the inclusion of a highly porous pumice fragment as mentioned above.

Table 14. Porosity data for tuffs

[Data reported in units as received from Surtek, Inc., laboratory]

\begin{tabular}{lcc}
\hline Sample name & $\begin{array}{c}\text { Porosity } \\
\text { before } \\
\text { compression } \\
\text { (percent) }\end{array}$ & $\begin{array}{c}\text { Porosity after } \\
\text { compression } \\
\text { (percent) }\end{array}$ \\
\hline UZ5-335 & Nonwelded tuff & \\
GTO-JJ-DB-1A-2-1 & 24.40 & 18.48 \\
GT-LD-AC2-55 & 38.63 & 21.84 \\
GT-LD-AC2-62 & Densely welded tuff & \\
\hline
\end{tabular}

'All the samples listed were compressed to a maximum axial stress of $552 \mathrm{MPa}$ using one-dimensional compression.

The pore-size distribution and porosity data collected using mercury porosimetry indicate two conclusions that apply to the one-dimensional compression of tuff cores: (1) for nonwelded tuff cores, large pores are reduced in size as the total pore volume of the core is decreased, and (2) for densely welded tuff cores, compression does not have a large impact on the pore-size distribution.

\section{Optical Microscopic Studies}

Thin sections from samples of 16 of the tuff cores used for triaxial or one-dimensional compression were examined using a petrographic microscope to further investigate changes in the tuff pore structure caused by compression. The set of tuff cores was chosen using three selection criteria: (1) include cores compressed to different maximum axial stresses, (2) include cores from a variety of lithologic units, and (3) include all the samples in the group chosen for quantitative mineralogical analysis to allow direct 
comparison of optical characteristics to quantitative mineralogy. A list of these samples is included in table 15.

Table 15. Samples used for petrographic examination

[MPa, megapascals]

\begin{tabular}{|c|c|c|}
\hline Sample name & $\begin{array}{l}\text { Maxl- } \\
\text { mum } \\
\text { axlal } \\
\text { stress } \\
\text { (MPa) }\end{array}$ & Formation \\
\hline \multicolumn{3}{|c|}{ Triaxial compression } \\
\hline UZA-240 & 76 & Pah Canyon Member \\
\hline UZA-241 & 117 & Pah Canyon Member \\
\hline UZ4-242 & 165 & Pah Canyon Member \\
\hline UZ5-246 & 179 & Pah Canyon Member \\
\hline UZ5-269 & 179 & Pah Canyon Member \\
\hline UZ5-334 & 152 & Topopah Spring Member \\
\hline \multicolumn{3}{|c|}{ One-dimensional compression } \\
\hline UZA-115 & 427 & Yucca Mountain Member \\
\hline UZ5-335 & 552 & Topopah Spring Member \\
\hline UZ5-347 & 552 & Topopah Spring Member \\
\hline GTO-JJ-DB-1A-1-1 & 5.52 & Tunnel bed 5 \\
\hline GTO-JJ-DB-1A-2-1 & 552 & Tunnel bed 5 \\
\hline GTO-JJ-DB-1B-1-1 & 552 & Tunnel bed 5 \\
\hline GT-EX-DH3-2 & 552 & Tunnel bed 5 \\
\hline GT-EX-DH3-3 & 552 & Tunnel bed 5 \\
\hline GT-LD-AC2-55 & 552 & Grouse Canyon Member' \\
\hline GT-LD-AC.2-62 & 552 & Grouse Canyon Member' \\
\hline
\end{tabular}

'Densely welded tuff; all other samples are nonwelded tuffs.

Two subsamples were collected from each core to represent the tuff pore structure before and after compression. Fragments of the core end pieces cut during sample preparation were used for the beforecompression subsamples. Pieces of the compressed cores served as the after-compression subsamples. Two thin sections were made from each subsample. One thin section was cut parallel to the long axis of the core; one thin section was cut perpendicular to the long axis of the core. (For a thin section cut from a compressed core, the thin section parallel to the long axis of the core represented a view along the direction of stress application.) The locations of the thin sections were chosen as close together as possible to minimize varia- tion due to sample heterogeneity. All thin sections were standard size (about $22 \mathrm{~mm} \times 27 \mathrm{~mm}$ ) and were impregnated with blue epoxy to highlight the pore space. Thin sections were prepared by Petrographic Services, Inc., in Aurora and Montrose, Colorado.

A total of 64 thin sections were observed using an Olympus model BH-2 petrographic microscope. Magnification factors of $4 x$ and $10 x$ were used in examination of the thin sections. At a magnification of $10 \mathrm{x}$, the smallest feature measurable using the microscope cross-hair scale was about $5 \mu \mathrm{m}$; the smallest visible feature was about $1 \mu \mathrm{m}$. The thin sections cut from before-compression subsamples were examined to provide a basis for comparison to the after-compression subsamples for each individual core. The thin sections were examined only for evidence of changes in the matrix/pore structure, and not for mineralogical analysis.

Two main characteristics were examined in the analysis of the thin sections for changes in pore structure: (1) size and distribution of visible pores, and (2) frequency, size, and distribution of fractures. The following discussion of the results of the thin section analysis is separated into two parts based on the degree of welding of the tuff samples.

\section{Nonwelded Tuff}

The set of 64 thin sections included 56 thin sections from nonwelded tuff samples. Discussion of observations made on these thin sections is separated into sections according to lithologic unit.

\section{Tunnel Bed 5}

Determination of changes in the pore structure of the nonwelded tuff samples from Tunnel bed 5 was limited because these thin sections displayed a uniform, featureless matrix that contained few phenocrysts, pumice fragments, or lithic fragments. The thin sections of before-compression subsamples from Tunnel bed 5 contained many pores ranging in diameter from 20 to $50 \mu \mathrm{m}$. The after-compression thin sections, however, indicated that all of these pores were collapsed. Although the matrix showed the blue color of the impregnated epoxy (indicating porosity was present), the pore size in the matrix of the aftercompression thin sections was too small to observe using the petrographic microscope. The aftercompression thin sections from the Tunnel bed 5 samples (all compressed to $552 \mathrm{MPa}$ ) all displayed fracturing perpendicular to the direction of the applied axial stress. These thin sections also displayed fractures that 
had other orientations-both parallel to and at oblique angles to the direction of applied axial stress. The fractures oriented perpendicular to the direction of applied stress usually were confined to the tuff matrix and often extended the entire width of the thin section. These fractures oriented perpendicular to the applied stress may have resulted from the unloading of axial stress from the core after one-dimensional compression. Some of these fractures may have been created during extrusion of the sample from the one-dimensional compression cell.

\section{Yucca Mountain and Topopah Spring Members}

Observations of tuff samples from the Yucca Mountain and Topopah Spring Members were similar to those made for Tunnel bed 5 . Visible pores contained in the thin sections of the beforecompression subsamples were not contained in the after-compression thin sections. Samples from the Topopah Spring Member contained slightly more phenocrysts and lithic fragments than samples from Tunnel bed 5 . The phenocrysts and lithic fragments displayed increased numbers of fractures after compression. Some of the thin sections of the after-compression subsamples from the Topopah Spring Member also contained large, extensive fractures oriented perpendicular to the applied axial stress similar to those observed in thin sections from Tunnel bed 5 samples. Only samples UZ5-335 and UZ5-347 (that were compressed to $552 \mathrm{MPa}$ ) contained these large fractures; thin sections from sample UZ5-334 (compressed to $152 \mathrm{MPa}$ ) did not exhibit large, extensive fractures.

\section{Pah Canyon Member}

Only samples from the Pah Canyon Member displayed enough lithologic variability to allow detailed study of the changes in the distribution of fractures caused by compression. Thin sections of tuff cores from this unit contained numerous pumice fragments, lithic fragments, and phenocrysts in a matrix mainly composed of altered and unaltered glass shards. In thin sections of before-compression subsamples, pores within the matrix usually were not visible; however, pores that had an average diameter of about $20 \mu \mathrm{m}$ were common within pumice fragments. Very few fractures were present in the thin sections of the beforecompression subsamples; fractures that were present occurred only within phenocrysts. Pumice fragments in thin sections of after-compression subsamples were noticeably compressed and usually did not contain visible pores. After compression fractures through and around phenocrysts, lithic fragments, and pumice frag- ments were common; fractures through the matrix were observed less frequently.

Three sample sets ( 12 thin sections) representing cores from the Pah Canyon Member were examined in detail to make a more accurate estimate of the increase in the frequency of fracturing caused by compression. The three test cores (UZ4-240, UZ4-241, and UZ4-242) were adjacent pieces all obtained from the same original core segment. These three cores were compressed to different maximum axial stresses (76, 117, and $165 \mathrm{MPa}$, respectively) specifically for the purpose of providing samples for this detailed petrographic analysis. Both the before- and aftercompression subsamples contained four main lithologic components: phenocrysts, pumice fragments, lithic fragments, and matrix. In thin sections of all these samples, the phenocrysts were fractured the most frequently; therefore, the phenocrysts were selected for observation to study fracture density. Only phenocrysts that had long axes greater than about $250 \mu \mathrm{m}$ in length were used in the investigation to limit the total number of phenocrysts observed and to facilitate counting the fractures.

For the purposes of determining fracture density, only fractures that had widths greater than about $3 \mu \mathrm{m}$ were counted. This fracture width is arbitrary. However, because phenocrysts often contained many hairline $(<1$ to $2 \mu \mathrm{m})$ fractures, restricting the number of fractures counted was necessary. The density of fracturing within a phenocryst was divided into five categories based on the number of fractures contained in the phenocryst: zero, one, two, three, or four or more. The following procedure was used to determine the fracture density for each of the 12 thin sections. An area $20 \mathrm{~mm}$ by $20 \mathrm{~mm}$ in the center of each thin section was divided into 400 grid locations. Twenty of these grid locations were selected randomly for observation. (The selection was done by assigning each of the locations a value between 1 and 400 and using a random number table to choose 20 of the locations.) Using a point-counting stage on the microscope, each of the chosen locations was moved into view in turn. Using the microscope at $4 \mathrm{x}$ magnification, the fractures in each phenocryst more than 50 percent within the field of view were counted. Each phenocryst was assigned the appropriate fracture density classification according to the number of fractures it contained; the number of phenocrysts in each fracture density category was recorded for each of the 20 fields of view.

A total of 3,790 phenocrysts were counted to determine the density of fracturing present in the set of 12 thin sections. The results of this analysis are listed in table 16 and presented as a frequency histogram in figure 32 . The most elementary observation that may 
Table 16. Data for fracture density analysis

[Fracture density catagory indicates the number of fractures in each phenocryst]

\begin{tabular}{|c|c|c|c|c|c|c|c|c|c|c|c|}
\hline \multirow{3}{*}{ Sample name' } & \multicolumn{6}{|c|}{ Phenocrysts counted } & \multicolumn{5}{|c|}{ Relative frequency (percent) } \\
\hline & \multicolumn{6}{|c|}{ Fracture density category } & \multicolumn{5}{|c|}{ Fracture density category } \\
\hline & 0 & 1 & 2 & 3 & $\begin{array}{l}4 \text { or } \\
\text { more }\end{array}$ & Total & $\mathbf{0}$ & 1 & 2 & 3 & $\begin{array}{l}4 \text { or } \\
\text { more }\end{array}$ \\
\hline & \multicolumn{11}{|c|}{ Before compression } \\
\hline UZ4-240-BC-X & 273 & 43 & 16 & 2 & 1 & 335 & 81 & 13 & 5 & 1 & 0 \\
\hline UZ4-240-BC-Z & 186 & 23 & 1 & 0 & 0 & 210 & 89 & 11 & 0 & 0 & 0 \\
\hline UZ4-241-BC-X & 278 & 31 & 14 & 0 & 0 & 323 & 86 & 10 & 4 & 0 & 0 \\
\hline UZA-241-BC-Z & 266 & 29 & 16 & 1 & 0 & 312 & 86 & 9 & 5 & 0 & 0 \\
\hline $\mathrm{UZ4-242-BC-X}$ & 266 & 17 & 11 & 1 & 7 & 302 & 88 & 6 & 4 & 0 & 2 \\
\hline \multirow[t]{3}{*}{ UZ2-242-BC-Z } & \multirow[t]{2}{*}{263} & \multirow{2}{*}{39} & \multirow[t]{2}{*}{15} & \multirow[t]{2}{*}{4} & \multirow[t]{2}{*}{3} & 324 & 81 & 12 & 5 & 1 & 1 \\
\hline & & & & & & weighted average ${ }^{2}$ & 85 & 10 & 4 & 0 & 1 \\
\hline & & & & & \multicolumn{2}{|c|}{ After compression } & & & & & \\
\hline $\mathrm{UZ4}-240-\mathrm{AC}-\mathrm{X}^{3}$ & 264 & 45 & 13 & 8 & 6 & 336 & 79 & 13 & 4 & 2 & 2 \\
\hline \multirow[t]{2}{*}{$\mathrm{UZ} 4-240-\mathrm{AC}-\mathrm{Z}^{3}$} & \multirow[t]{2}{*}{242} & \multirow[t]{2}{*}{21} & \multirow[t]{2}{*}{11} & 1 & \multirow[t]{2}{*}{11} & 286 & 85 & 7 & 4 & 0 & 4 \\
\hline & & & & & & weighted average ${ }^{2}$ & 82 & 10 & 4 & 1 & 3 \\
\hline UZ4-241-AC- $X^{4}$ & 260 & 41 & 39 & 10 & 6 & 356 & 73 & 12 & 11 & 3 & 2 \\
\hline \multirow[t]{2}{*}{$\mathrm{UZ4-241-AC-Z^{4 }}$} & \multirow[t]{2}{*}{165} & \multirow[t]{2}{*}{35} & \multirow[t]{2}{*}{25} & 18 & \multirow[t]{2}{*}{22} & 265 & 62 & 13 & 9 & 7 & 8 \\
\hline & & & & & & weighted average ${ }^{2}$ & 68 & 12 & 10 & 5 & 5 \\
\hline UZ4-242-AC-X ${ }^{5}$ & 241 & 51 & 41 & 26 & 64 & 423 & 57 & 12 & 10 & 6 & 15 \\
\hline \multirow{2}{*}{$\mathrm{UZ4-242-AC-Z^{5 }}$} & \multirow[t]{2}{*}{176} & \multirow[t]{2}{*}{67} & \multirow[t]{2}{*}{27} & 27 & \multirow[t]{2}{*}{21} & 318 & 55 & 21 & 8 & 8 & 7 \\
\hline & & & & & & weighted average ${ }^{2}$ & 56 & 16 & 9 & 7 & 12 \\
\hline
\end{tabular}

1 . parallel to the long axis of the core.

2 Averages weighted using total number of phenocrysis counted.

${ }^{3}$ Sample UZ4-240 was compressed to a maximum axial stress of $76 \mathrm{MPa}$ using triaxial compression.

${ }^{4}$ Sample UZA-241 was compressed to a maximum axial stress of $117 \mathrm{MPa}$ using triaxial compression.

5 Sample UZA-242 was compressed to a maximum axial stress of $165 \mathrm{MPa}$ using triaxial compression. 
be made from these data is that the number of fractured phenocrysts increases as the applied axial stress is increased. Some refinements of this general trend are possible if the data are examined more closely. The only difference between samples subjected to no stress and samples compressed using an applied axial stress of $76 \mathrm{MPa}$ is a small increase in the number of phenocrysts that occupy the two categories that represent the most dense fracturing. However, when the applied axial stress was increased to 117 and then $165 \mathrm{MPa}$, the number of unbroken phenocrysts declined rapidly while the number of phenocrysts in all the classes of fracturing increased.

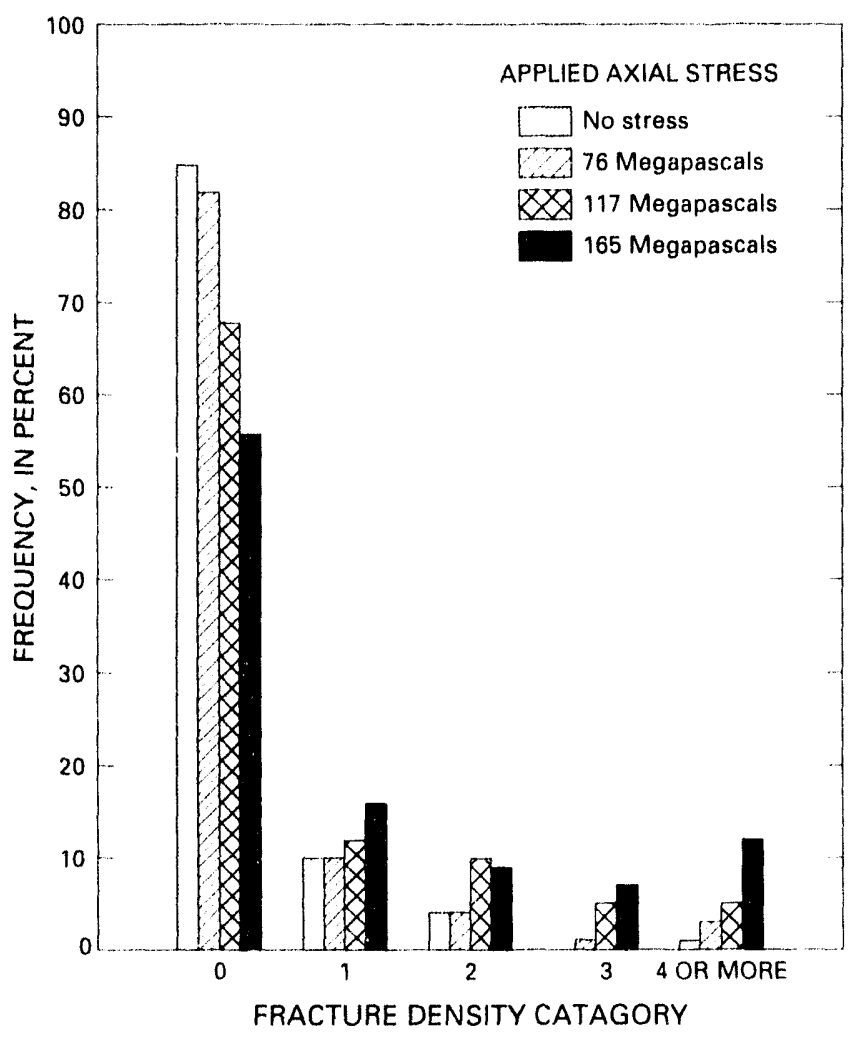

Figure 32. Relative density of fractures in phenocrysts in nonwelded tuff cores tested using triaxial compression. Fractures counted in thin sections from samples UZ4-240, UZ4-241, and UZ4-242.

\section{Nonwelded Tuff Summary}

The pore structure of nonwelded tuff cores does change as a result of compression. The following list summarizes the observations that support this statement:

1. Pores that were visible before compression were no longer visible after compression. The reduction in open pores was observed in nearly all the aftercompression thin sections.
2. Few fractures were present before compression; after compression, fractures were found within, around, and through lithic fragments and phenocrysts as well as through the tuff matrix. Large, extensive fractures oriented perpendicular to the applied axial stress occurred frequently in samples that were compressed to $552 \mathrm{MPa}$.

3. The density of fracturing within phenocrysts increased as applied axial stress was increased.

\section{Densely Welded Tuff}

The set of 64 thin sections contained a total of 8 densely welded tuff thin sections from the Grouse Canyon Member (samples GT-LD-AC2-55 and GT-LDAC2-62). The before-compression thin sections of samples from the Grouse Canyon Member displayed a varied distribution of pores. Numerous small $(<5 \mu \mathrm{m})$ pores were present in portions of the matrix, but other sections of the matrix exhibited no visible pores. Pores ranging in diameter from 5 to $30 \mu \mathrm{m}$ were also observed within large phenocrysts. A few large pores (up to $0.8 \mathrm{~mm}$ in diameter) were also present in zones that appeared to be zeolitized. The after-compression thin sections from samples of the Grouse Canyon Member displayed little change from the beforecompression subsamples-all the same classes of pores (even the large pores) were present in the aftercompression thin sections. However, the matrix and phenocrysts appeared much more densely fractured after compression. Note that fractures in the matrix of all the densely welded tuff samples most frequently passed directly through phenocrysts and not around them as was commonly observed in the nonwelded tuff samples.

\section{INTERPRETATION OF MECHANICAL DATA}

\section{Mechanical Behavior of Tuff}

Curves illustrating the relation between applied axial stress and measured axial strain are presented in figuie 33. Three curves are displayed: (1) nonwelded tuff using triaxial compression, (2) nonwelded tuff using one-dimensional compression, and (3) densely welded tuff using one-dimensional compression. (These three curves were constructed from the same data as presented in figures 11,18 , and 19 , respectively.)

Each of the two nonwelded tuff curves can be separated into three regions. Over the initial section of 
each curve (segment $A B$ ) axial strain increases more rapidly than axial stress; this part of the curve may represent the collapse of the largest pores. The middle section of each curve (segment BC) indicates a roughly linear relation between axial stress and axial strain. This section of the curve does not, however, represent elastic deformation. The amount of permanent strain remaining in the core after unloading was measured during 29 of the 32 compression tests done on nonwelded tuff cores; an average of 80 percent of the total axial strain was not recovered when the core was unloaded. (Refer to tables 2 and 4 for data concerning permanent, nonrecoverable strain.) The final section of the curve (segment CD) indicates creep in the core as the axial stress is held constant.

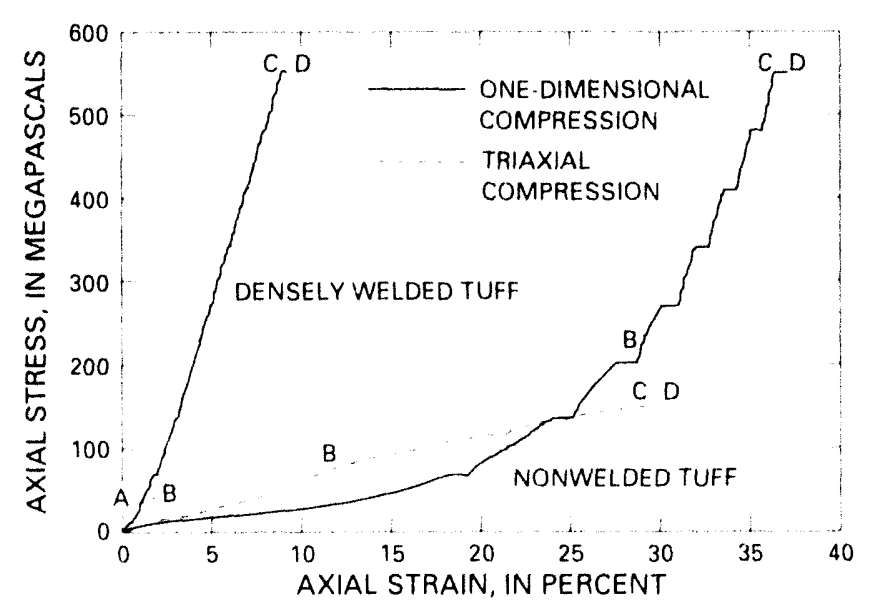

Figure 33. Deformational behavior of tuff cores during compression. Point $A$ is located at the origin of the graph.

The densely welded tuff curve can also be divided into three regions. The initial section of the curve (segment $A B$ ) is much shorter for the densely welded tuff curve than for the nonwelded tuff curve. The middle section of the curve (segment BC) displays a long linear region in which axial stress and axial strain are proportional. For densely welded tuff cores, this section of the curve probably does represent elastic deformation. The amount of permanent strain remaining in the core after unloading was measured during 16 of the 17 welded tuff compression tests; an average of 70 percent of the total axial strain was recovered when the core was unloaded (see tables 2 and 4 ). Similar to the nonwelded tuff curves, the final section of the curve (segment $C D$ ) indicates creep as axial strain continues at a constant axial stress.

Observations concerning core mineralogy, poresize distribution, and optical characteristics support the mechanical behavior of the tuff cores as described above. Nonwelded tuff cores exhibited a weak, inelas- tic deformational behavior. This statement is reinforced by the following observations: (1) nonwelded tuff cores had large values of initial porosity and were composed mainly of minerals that have small compressive strengths (zeolites and clay minerals), (2) lithologic components in nonwelded tuff cores were poorly held together (matrix fractures often bypassed phenocrysts and lithic fragments), and (3) compression created a noticeable decrease in the average pore diameter. Densely welded tuff cores, in contrast, displayed a strong, elastic deformational behavior. Observations of densely welded tuff cores that support this behavior include: (1) densely welded tuff cores had small values of initial porosity and were composed of minerals that have large compressive strengths (sanidine and quartz), (2) lithologic components in densely welded tuff cores were tightly connected by the matrix (fractures in the matrix usually passed through phenocrysts and lithic iragments), and (3) compression did not produce a noticeable change in the pore-size distribution.

Water expulsion from a densely welded or nonwelded tuff core may hegin at any point along the curve depending on the initial moisture content of the core. Cores that had large initial moisture contents produced water in segment $\mathrm{AB}$, while cores that contained less pore water yielded water in segment BC. The driest cores produced water only after gas injection while the core was held at a constant axial stress in segment $C D$. For example, nonwelded tuff sample GTO-JJ-DB-1A1-1 had an initial moisture content of about 26 percent, an initial saturation of 91 percent, and began producing water at an axial stress of about $36 \mathrm{MPa}$ - well within segment $A B$. Water recovery from nonwelded tuff sample UZ5-345 (initial moisture content about 12 percent and initial saturation of 37 percent) began in segment $\mathrm{BC}$ at an axial stress of about $410 \mathrm{MPa}$. Densely welded tuff sample GT-LD-AC2-62 had an initial moisture content of about 6.6 percent, an initial saturation of 80 percent and produced water using gas injection at an axial stress of $552 \mathrm{MPa}$-in segment $\mathrm{CD}$. A more detailed discussion of the relation between core moisture conditions and axial strain is presented below in "Volumetric Relations."

\section{Volumetric Relations}

Extraction of pore water from tuff cores using one-dimensional compression allows accurate volumetric calculations to be made as the core is compressed. (Because these same calculations are not possible for the triaxial compression system used in this study, only results from tests using onedimensional compression will be included in the fol- 
lowing discussion.) After a core has reached a state of 100 percent saturation, each increment of compression produces an increment of pore-water expulsion. For a core that has a diameter of $61 \mathrm{~mm}$, each $1 \mathrm{~mm}$ length reduction corresponds to $2.9 \mathrm{~mL}$ of pore-volume reduction. After enough water has been expelled from a core to completely fill the drainage system (up to the syringes), the incremental water expulsion can be measured in the collection syringes. The direct relation between length reduction (axial strain) and pore-water recovery was observed during one-dimensional compression of sample GT-EX-DH3-3 and is illustrated in figure 34. The same direct relation was found for 14 of the 17 nonwelded tuff cores tested using onedimensional compression; the other three cores (samples UZ4-338, UZ5-217, and UZ5-230) either did not produce water or only produced water when gas injection was used. This relation could not be demonstrated for densely welded tuff cores because none of the densely welded tuff cores produced sufficient water during core compression.

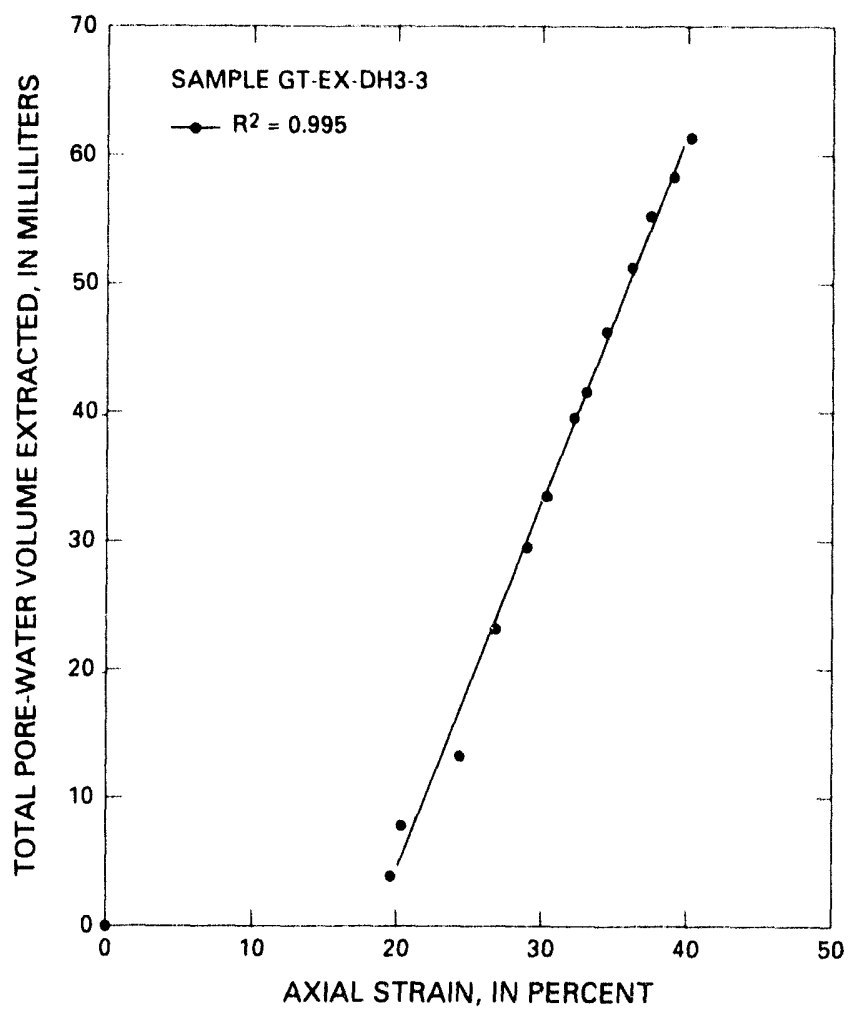

Figure 34. Relation between axial strain and volume of pore water extracted from sample GT-EX-DH-3 using one-dimensional compression.
The volumetric changes in a core during onedimensional compression can also be used to monitor the change in the moisture content of the core as it is compressed. As pore water is expelled from a core, the moisture content of the core continually decreases. Data from the same group of 14 nonwelded tuff cores mentioned above indicate this relation (fig. 35 ). The decrease in moisture content ranged from 16 to 60 percent, and the average decrease was 42 percent. (The decrease in moisture content was calculated as the difference between the initial and final moisture contents divided by the initial moisture content. The final core moisture content was calculated based on the initial moisture content and the volume of water extracted.) It is important to note in figure 35 that all the curves are roughly subparallel; the moisture content of this group of nonwelded tuff cores does not appear to decrease toward a single minimum value over the range of applied axial stress.

\section{Comparison Between Triaxial and One- Dimensional Compression}

The one-dimensional compression system was more effective in reducing pore space than the triaxial compression system used in this study. The onedimensional compression system also was more efficient in extracting pore water from nonwelded tuff cores that had small initial moisture contents. A list of the average values obtained from the tests done for this study is presented in table 17 . The enhanced effectiveness of the one-dimensional compression system in comparison to the triaxial compression system is due primarily to the much larger axial stress that the onedimensional compression cell can apply to a core.

Curves relating initial moisture content and volume of pore water extracted from nonwelded tuff cores using both triaxial and one-dimensional compression are displayed in figure 36 . The two curves indicate the same general trend-both compression methods are effective in removing pore water from nonwelded tuff cores. However, as indicated by the data for cores that had small initial moisture contents, one-dimensional compression is the more effective method for porewater extraction from dry nonwelded tuff cores. 
Table 17. Comparison of triaxial and one-dimensional compression

[pct, percent; --, no data available]

\begin{tabular}{|c|c|c|}
\hline & $\begin{array}{l}\text { Triaxial } \\
\text { compres- } \\
\text { slon }\end{array}$ & $\begin{array}{c}\text { One- } \\
\text { dimenalonal } \\
\text { compression }\end{array}$ \\
\hline \multicolumn{3}{|c|}{ Nonwelded turf } \\
\hline Porosity reduction (pct) & 37 & 63 \\
\hline Total axial strain (pct) & 24 & 37 \\
\hline $\begin{array}{l}\text { Pore-water extraction } \\
\text { success }^{1}(\mathrm{pct})\end{array}$ & 37 & 41 \\
\hline $\begin{array}{l}\text { Minimum initial moisture } \\
\text { content }^{2}(\mathrm{pct})\end{array}$ & 11 & 7.6 \\
\hline \multicolumn{3}{|c|}{ Densely welded tuff } \\
\hline Porosity reduction (pct) & -- & 37 \\
\hline Total axial strain (pct) & -- & 9 \\
\hline $\begin{array}{l}\text { Pore-water extraction } \\
\text { success }{ }^{\prime} \text { (pcl) }\end{array}$ & -- & 11 \\
\hline $\begin{array}{l}\text { Minimum initial moisture } \\
\text { content }^{2}(\mathrm{pct})\end{array}$ & $\cdots$ & 6.5 \\
\hline
\end{tabular}

All values (except minimum initial moisture content) represent average values.

'Pore-water extraction success is based on the total volume of pore water extracted-including water produced using gas injection.

${ }^{2}$ Minimum initial moisture content that resulted in extraction of pore water; includes use of gas injection.

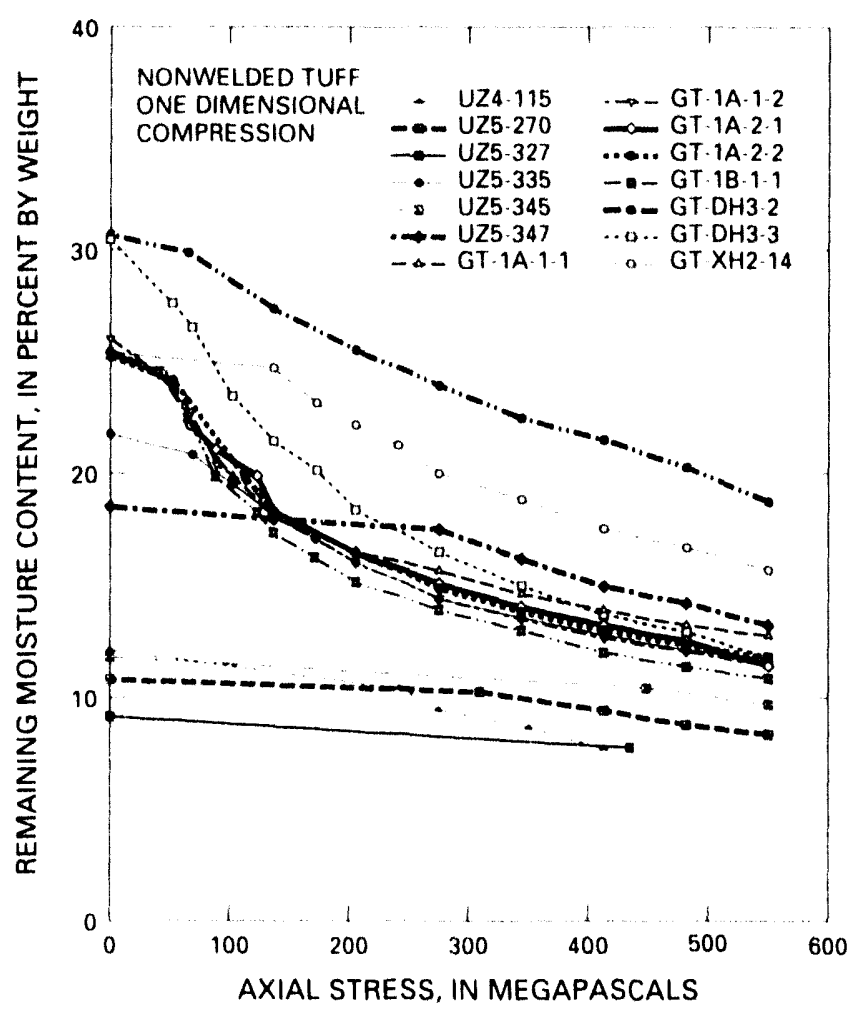

Figure 35. The effect of increasing axial stress on core moisture content for cores tested using one-dimensional compression.

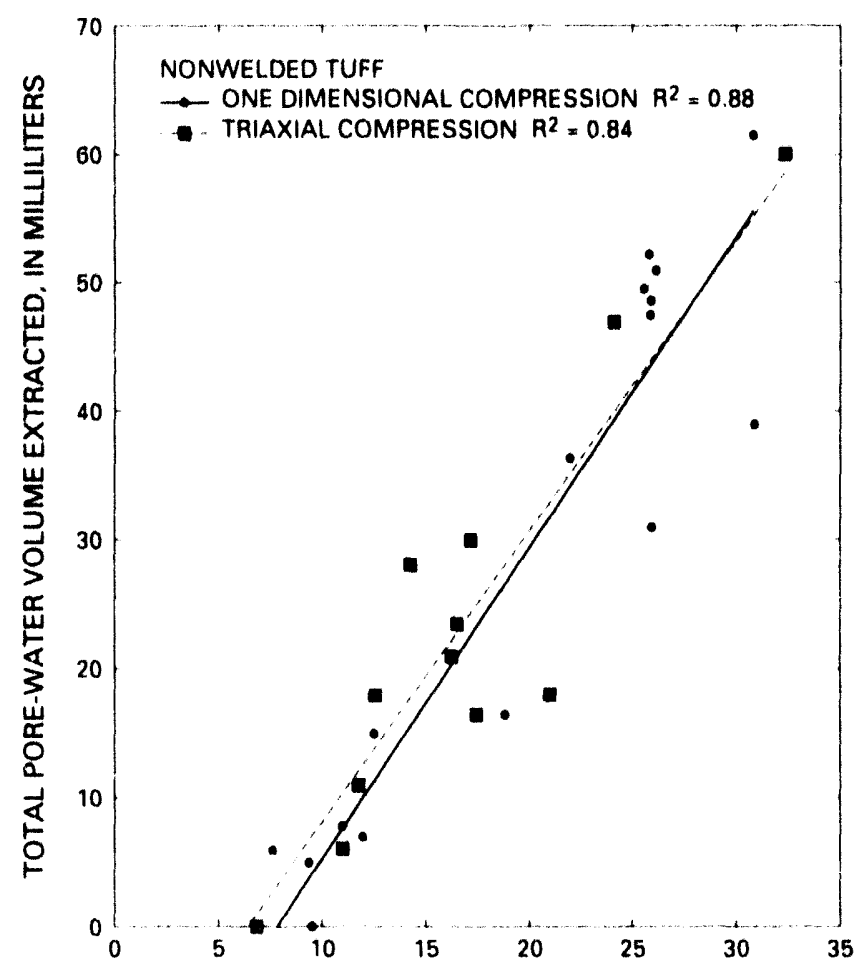

INITIAL MOISTURE CONTENT, IN PERCENT BY WEIGHT

Figure 36. Total volume of pore water extracted from nonwelded tuff cores using triaxial and one-dimensional compression. Volume of pore water recovered using gas injection is included for both compression methods.

\section{DISCUSSION}

\section{Advantages of One-Dimensional Compression}

For the extraction of pore water from unsaturated tuff cores, one-dimensional compression has many advantages over other pore-water extraction methods.

A list of these advantages, in comparison to triaxial compression, is presented below. Comparisons to centrifugation are included where adequate published information exists to support the comparison. Other extraction methods including: vacuum distillation, dilution, and immiscible displacement are not discussed because these methods, in general, are not suitable for pore-water extraction when accurate determination of the dissolved ionic chemistry of the pore water is necessary.

1. Larger applied axial stress. The onedimensional compression cell used in this study can apply more than 2.5 times the axial stress to a core than previously used triaxial compression cells. Larger 
axial stress causes more pore space to be eliminated during compression, which, in turn, results in increased water expulsion in nonwelded tuff cores. High levels of axial stress are required to cause water expulsion from cores of nonwelded tuffs that have initial moisture contents less than about 11 percent and from cores of densely welded tuffs that have initial moisture contents ranging from 6.5 to 8.8 percent.

2. Quantitative volumetric measurements. Because the core diameter is rigidly constrained during one-dimensional compression, accurate volumetric measurements are possible. Lateral strain can occur during triaxial compression, and, therefore, accurate volume change measurements cannot be made. (Measurements of lateral strain-not possible with the triaxial compression equipment used in this study - would allow approximate volumetric measurements during compression.) Volumetric measurements during centrifugation also are not possible due to the construction of most centrifuge rotors. Measurements of changes in core volume during compression are useful in predicting the approximate timing and volume of water expulsion.

3. Variable core length. The one-dimensional compression cell can accommodate a large range of core lengths. Standard triaxial compression cells and centrifuge rotors require closely constrained core sizes. (Modifications to standard triaxial compression and centrifugation equipment could reduce or eliminate this advantage.)

4. Smaller system volume. About $1 \mathrm{~mL}$ of water must be expelled into the collection system of the onedimensional compression cell before water recovery is observed in the collection syringes. The triaxial compression cell used in this study required about $8 \mathrm{~mL}$ to fill the collection system up to the syringes. (Again, modifications to the triaxial cell could reduce the required system volume.) Observation of water expulsion and direct measurement of water volume are not possible during centrifugation. A small system volume allows rapid recognition of water expulsion and minimizes the loss of water that adheres to the inside of the water drainage pathways.

5. Lower contamination risk. Because steel applies the confining force in the one-dimensional compression cell, there is no risk of contamination caused by leakage of the confining fluid as can occur in the triaxial compression cell.

Of all the listed advantages, the larger stress capacity of the one-dimensional compression cell is the most important. Larger axial stresses produce larger volumes of expelled pore water in nonwelded tuff cores that have similar initial moisture contents. Large axial stresses also enable extraction of pore water from non- welded tuff cores that have small initial moisture contents and from densely welded tuff cores; neither of these two groups of tuff samples would produce water using triaxial compression or centrifugation.

\section{Appropriate Pore-Water Extraction Method for Tuffs from Yucca Mountain}

The most appropriate method for pore-water extraction from tuffs from Yucca Mountain can be selected based on two criteria: (1) the minimum initial moisture content required for successful pore-water extraction, and (2) the impact the method has on the original, in-situ pore-water chemistry. The two methods investigated in this study-triaxial compression and one-dimensional compression-are considered below in relation to the two selection criteria.

\section{Minimum Initial Moisture Content}

The minimum initial moisture content for successful pore-water extraction from nonwelded tuff cores using triaxial compression was 11 percent; for one-dimensional compression, this value was 7.6 percent. Montazer and Wilson (1984) listed the average initial moisture content of nine nonwelded tuff samples from Yucca Mountain as 19 percent. The average initial moisture content of 11 nonwelded tuff cores from Yucca Mountain boreholes UE-25 UZ \#4 and UE-25 UZ \#5 tested in this study was 13 percent. (Note that this group of 11 cores excludes cores that had been sealed in PVC liner because moisture may have escaped from the PVC liner during storage.) Therefore, both extraction methods probably would be successful in removing pore water from Yucca Mountain nonwelded tuff cores that had average (13 to 19 percent) initial moisture contents. One-dimensional compression may be a more useful method for extracting pore water from cores that have initial moisture contents that are below average.

The minimum initial moisture content for extraction of pore water from densely welded tuff cores using one-dimensional compression was 6.5 percent. Calculations indicated that the triaxial compression cell used in this study could not apply enough axial stress to remove pore water from densely welded tuff cores. Montazer and Wilson (1984) also presented moisture content data for Yucca Mountain welded tuff samples. This report listed the average moisture content of 35 moderately to densely welded tuff samples as 5.5 percent; the reported standard deviation was 2.8 percent. While Yucca Mountain welded tuff cores that have an average ( 5.5 percent) initial moisture content may be 
too dry to yield water using one-dimensional compression, many the cores that have initial moisture contents that are above average may produce water using one-dimensional compression. One-dimensional compression may be capable of removing water from some Yucca Mountain welded tuff cores; the triaxial compression cell used in this study probably cannot be used to extract pore water from any Yucca Mountain welded tuff cores.

The stratigraphic section ahove the water table at Yucca Mountain contains a much thicker sequence of moderately to densely welded tuffs than nonwelded tuffs. Based on thicknesses reported in Montazer and Wilson (1984), the unsaturated zone at Yucca Mountain is about 90 percent moderately to densely welded tuffs and only about 10 percent nonwelded tuffs. The most appropriate pore-water extraction method must, consequently, be based mainly on the ability of the method to remove pore water from welded tuff cores. One-dimensional compression can expel pore water from densely welded tuff cores. In addition, onedimensional compression has a smaller required initial moisture content for pore-water extraction from nonwelded tuff cores than triaxial compression. Therefore, based on the mechanical capabilities of these extraction methods, one-dimensional compression is more appropriate for pore-water extraction from Yucca Mountain tuff cores than triaxial compression.

Now that the one-dimensional compression system has been proven to work successfully on tuff cores, a new system can be designed, constructed and tested to optimize the amount of pore-water expulsion. A new one-dimensional compression cell with a pressure capacity greater than the existing cell should allow extraction of water from welded tuffs that have water contents around the average reported for Yucca Mountain tuffs.

\section{Impacts on Pore-Water Chemistry}

The effects that a pore-water extraction method has on the original, in-situ pore-water composition also must be considered in determining whether the method is appropriate. This work is in progress.

\section{Recommended Method}

Based on the mechanical ability of a porewater-extraction method to remove water from welded and nonwelded Yucca Mountain tuff cores that have small initial moisture contents, one-dimensional compression is a more appropriate extraction method than triaxial compression. However, the effects that onedimensional compression has on pore-water chemistry are not known at this time (the study is in progress). Although one-dimensional compression may be the leading choice for pore-water extraction from Yucca Mountain tuff cores, this extraction method will not be truly appropriate until the impacts of one-dimensional compression on pore-water chemistry are defined.

Experience gained from compression tests done for this study can provide guidelines for future porewater extraction tests using one-dimensional compression. The recommended loading history for pore-water extraction from densely welded and nonwelded tuff cores using one-dimensional compression are illustrated on figure 37. These loading histories are designed to extract the maximum amount of pore water from rocks with low moisture contents and low initial saturations. If the rock has a high initial moisture content and degree of saturation, then a steadily increasing loading history may be adequate to extract the desired quantity of water. Also, these loading histories were designed to collect pore-water samples at different pressure levels so that water chemistry can be monitored as pressure increases.

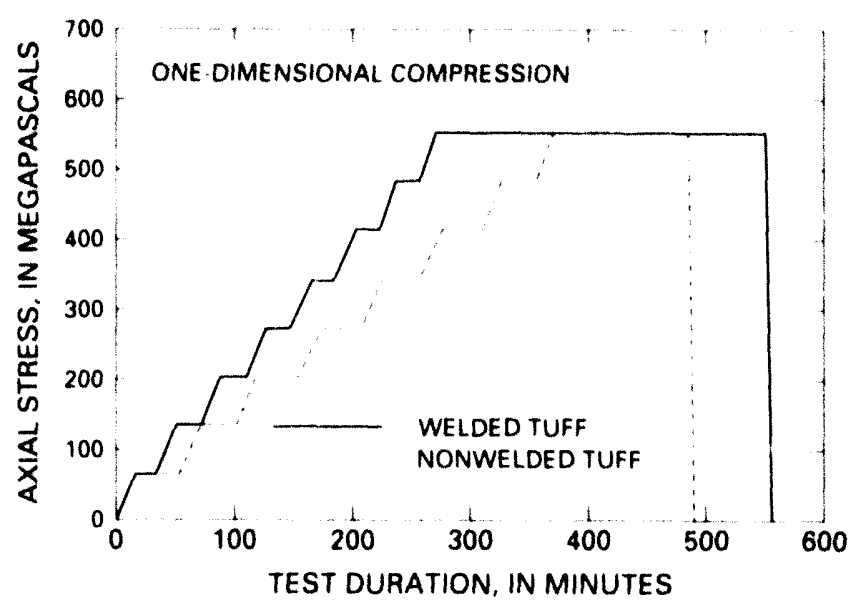

Figure 37. Recommended loading history for one-dimensional compression of densely welded and nonwelded tuff cores.

In addition to the suggested loading histories, the following procedural steps are recommended to maximize water recovery:

1. Axial stress should be maintained at each stress level until the rate-of-water expulsion into the collection system is less than $0.1 \mathrm{~mL}$ in 10 minutes.

2. Axial stress should be maintained at each stress level for at least 10 minutes (even if no water is expelled) to allow pore water time to move out of the core. This is particularly important at large axial stresses. 
3. For one-dimensional compression of densely welded tuff cores, after the maximum axial stress has been reached and water expulsion from the core has ceased, pressure from an inert gas should be applied to force out additional pore water. Injection of nitrogen gas at a pressure of at least $1.4 \mathrm{MPa}$ for at least 180 minutes is recommended to maximize pore-water recovery; however, the total volume of injected gas should not exceed 20 liters to reduce the potential for evaporation of pore water. Experience from testing during this study indicated that if no pore water had been recovered after about 60 minutes, continued gas injection was unlikely to produce any pore water.

4. For nonwelded tuff cores, one-dimensional compression to the maximum axial stress ( $552 \mathrm{MPa}$ ) probably eliminates the usefulness of gas injection due to either a large decrease in permeability because of closed pores or development of large fractures from brittle failure.

\section{SUMMARY AND CONCLUSION}

Study of the hydrologic system at Yucca Mountain requires the extraction of pore-water samples from welded and nonwelded, unsaturated tuffs. Two compression methods-triaxial compression and onedimensional compression-were examined for porewater extraction from unsaturated tuff cores. The two purposes of this study were: (1) to develop a repeatable technique for extracting pore water and gas from cores of unsaturated, nonwelded and densely welded tuffs, and (2) to investigate the effects of the extraction method on the original pore-fluid composition. A total of 17 iriaxial and 32 one-dimensional compression tests were done to develop extraction methods and to examine the causes of changes in pore-water chemistry due to the extraction process.

\section{Triaxial Compression}

Work done by other investigators using triaxial compression provided the starting point for the research undertaken in this study. A standard, commercially available triaxial cell was modified slightly and used to compress cores of nonwelded tuff. A maximum $193 \mathrm{MPa}$ axial stress was applied to the test core in a series of four steps $(76,117,152$, and $193 \mathrm{MPa})$ while a constant confining stress of $68 \mathrm{MPa}$ was maintained. For an average nonwelded tuff core $(102 \mathrm{~mm}$ long, $61 \mathrm{~mm}$ in diameter), the application of stress for a total of about 300 minutes caused the expulsion of pore water provided that the initial moisture content of the core was at least 13 percent by weight and the initial saturation was $\mathbf{4 2}$ percent.

The triaxial compression procedure was improved further by injecting nitrogen gas into the core while the core was compressed at the maximum axial stress to force out additional pore water. The addition of gas injection to the method reduced the minimum initial moisture content for successful porewater extraction from 13 to 11 percent and reduced the minimum initial saturation from 42 to 24 percent.

Experimental calculations plus experience gained from tests of two moderately welded tuff cores indicated that the triaxial compression cell used in this study could not apply adequate axial stress to expel pore water from cores of densely welded tuffs. This concern led to the design and fabrication of the one-dimensional compression system used in this research.

\section{One-Dimensional Compression}

The one-dimensional compression cell used in this study was constructed from hardened 4340-alloy and nickel-alloy steels. This device was designed to compress cores that were $61 \mathrm{~mm}$ in diameter and as long as $110 \mathrm{~mm}$ to a maximum axial stress of $552 \mathrm{MPa}$. Axial stress was applied to a core in eight equal steps from zero to the maximum axial stress of $552 \mathrm{MPa}$. The average total test duration for nonwelded tuff cores was about $\mathbf{4 8 0}$ minutes; for welded tuff cores, the average total test duration was approximately 540 minutes.

One-dimensional compression extracted pore water from nonwelded tuff cores that had initial moisture contents greater than about 7.6 percent and initial saturations greater than 18 percent. Injection of nitrogen gas did not produce additional pore water when the axial stress applied to a core was greater than $276 \mathrm{MPa}$. Subsequent analysis of the pore-size distribution and pore structure of nonwelded tuff cores subjected to $552 \mathrm{MPa}$ axial stress indicated that the reduction in pore diameter caused by compression may have prevented the penetration of gas into the pore system.

One-dimensional compression caused expulsion of pore water from densely welded tuff cores that had initial moisture contents greater than about 7.7 percent and initial saturations greater than 74 percent. Injection of nitrogen gas was responsible for most of the pore water recovered from densely welded tuff cores. Gas injection reduced the minimum initial moisture content required for water extraction to about 6.5 percent; and the initial saturation was reduced to 64 percent. 


\section{Gas Injection}

The injection of nitrogen gas into a core recovered additional pore water provided that the core had been compressed adequately to fully saturate the pore system. Gas injection in conjunction with the compression of nonwelded tuff cores was effective only when the axial stress applied to the core was less than $276 \mathrm{MPa}$; injection of gas into densely welded tuff cores produced additional pore water even at an axial stress of $552 \mathrm{MPa}$. An applied gas injection pressure of at least $1.4 \mathrm{MPa}$ was necessary to initiate pore-water expulsion.

Increasing the dura ion of gas injection generally increased the volume of pore water expelled. Water expulsion rates declined after 60 minutes of injection into nonwelded tuff cores and after injection had continued for 180 minutes into densely welded tuff cores. However, gas injection for extended periods may cause evaporation of pore water from the core and the collection system. Evaporation of pore water was determined to be a significant concern when the volume of gas passed through a core exceeded about 20 liters.

\section{Mineralogy and Pore Structure}

Quantitative mineralogical aıalysis of seven tuff samples was done to aid in the interpretation of porewater chemical data. Samples of nonwelded tuff cores from the Topopah Spring Member of the Paintbrush Tuff at Yucca Mountain and Tunnel bed 5 from G-Tunnel at Rainier Mesa contained between 53 and 76 percent zeolite (clinoptilolite) and lesser amounts of clay minerals. Samples of densely welded tuff cores from the Grouse Canyon Member of the Belted Range Tuff from G-Tunnel at Rainier Mesa contained mainly feldspars (sanidine and albite) and quartz, and included only small amounts of zeolites and clay minerals.

Analysis of the pore-size distribution and pore structure of samples of densely welded and nonwelded tuff cores was done to investigate the physical changes in the pore system of a tuff core caused by compression. Pore-size distributions-before and after compression to an axial stress of $552 \mathrm{MPa}$-were determined using mercury injection porosimetry. The diameter of most of the pore throats in nonwelded tuff cores decreased approximately ten-fold as a result of compression; the pore-size distributions for the samples of densely welded tuff cores were unchanged after compression.

Examination of thin sections using optical microscopy produced results in agreement with those of mercury injection porosimetry. Thin sections were cut from samples of tuff cores before and after compression to various levels of axial stress. Thin sections of nonwelded tuff cores compressed to $552 \mathrm{MPa}$ axial stress exhibited significantly fewer open pores than thin sections of uncompressed cores. Thin sections taken from densely welded tuff cores displayed little change in pore structure due to compression. The relative degree of fracturing was observed to increase as applied axial stress was increased in thin sections of both nonwelded and densely welded tuff cores.

\section{Mechanical Relations}

The deformational behavior observed in nonwelded and densely welded tuff cores was supported by the mineralogical composition and pore structure of each type of tuff. Nonwelded tuff cores exhibited large amounts of axial strain when subjected to relatively small ( $<200 \mathrm{MPa}$ ) axial stresses. The large initial porosities and large percentages of weak minerals probably are responsible for the inelastic behavior obstrved during the compression of nonwelded tuff cores. Densely welded tuff cores, in contrast, displayed much smaller amounts of axial strain even when compressed to $552 \mathrm{MPa}$. Small initial porosities and large proportions of strong minerals may cause the elastic response observed in densely welded tuff cores during compression.

Accurate volumetric measurements recorded during one-dimensional compression indicated that, after a core had been compressed adequately to reach a state of 100 percent saturation, the volume of water expelled was directly related to the axial strain. Each $1 \mathrm{~mm}$ of length reduction expelled $2.9 \mathrm{~mL}$ of pore water-just as predicted by the simple decrease in volume. While this is not an unexpected result, the direct correlation does confirm that accurate volumetric measurements can be made during one-dimensional compression.

\section{Conclusion}

Based on data in this report and published values, the average moisture content of nonwelded tuffs from Yucca Mountain ranges from 13 to 19 percent. The minimum initial moisture content for successful porewater extraction from nonwelded tuff cores using triaxial compression was 11 percent ( 24 percent initial saturation); for one-dimensional compression, this value was 7.6 percent (18 percent initial saturation). Both extraction methods probabiy would be successful in 
removing pore water from most Yucca Mountain nonwelded tuff cores.

Welded tuffs from Yucca Mountain, however, have much smaller initial moisture contents than nonwelded tuffs. Data reported by other investigators indicated the average moisture content of Yucca Mountain welded tuffs is about 5.5 percent. Experimental calculations plus experience gained from tests of two moderately welded tuff cores indicated that the triaxial compression cell used in this study could not apply adequate axial stress to expel pore water from cores of densely welded tuffs. The minimum initial moisture content for extraction of pore water from densely welded tuff cores using one-dimensional compression was 6.5 percent (64 percent initial saturation). Onedimensional compression may be capable of removing water from some Yucca Mountain welded tuff cores; the triaxial compression cell used in this study probably cannot be used to extract pore water from Yucca Mountain welded tuff cores.

The effects that a pore-water extraction method has on the original, in-situ pore-water composition also was investigated. The triaxial compression tests done on nonwelded tuff cores for this study did not produce suites of extracted water samples over a range of axial stress. The limited number of pore-water samples recovered using triaxial compression prevented direct analysis of the impacts of triaxial compression on porewater chemistry.

The large number of pore-water samples from nonwelded tuff cores recovered over the entire range of applied axial stress using one-dimensional compression will allow analysis of the effects of onedimensional compression on pore-water chemistry. The lack of suites of water samples over a range of axial stress prevent direct examination of the effects of one-dimensional compression on the pore water in densely welded tuff cores. Therefore, additional extraction tests are required on welded tuff cores to collect pore-water samples at various strese levels.

Based on the mechanical ability of a porewater-extraction method to remove water from welded and nonwelded Yucca Mountain tuff cores, onedimensional compression is a more appropriate extraction method than triaxial compression. However, the effects that one-dimensional compression has on porewater chemistry are not completely understood. Additional testing and water analyses will be needed to verify that this method is completely suitable for porewater extraction from Yucca Mountain tuffs. Water analyses should provide information on whether compression does alter pore-water chemistry, and if it does, the extent of that alteration.

\section{SELECTED REFERENCES}

American Society for Testing and Materials, 1988a, Laboratory determination of water (moisture) conient of soil, rock, and soil-aggregate mixtures: Annual Book of ASTM Standards, v. 4.08, D 2216-80, p. 262-264. (NNA.940606.0059)

American Society for Testing and Materials, 1988b, Triaxial compressive strength of undrained rock core specimens without pore pressure measurements: Annual Book of ASTM Standards, v. 4.08, D 2664-86, p. 307-309. (NNA.940606.0060)

American Society for Testing and Materials, 1988c, Standard practice for preparing rock core specimens and determining dimensional and shape tolerances: Annual Book of ASTM Standards, v. 4.08, D 4543-85, p. 727-730. (NNA.940606.0061)

Baidyuk, B.V., 1967, Mechanical properties of rocks at high temperatures and pressures: Consultants Bureau, Plenum Publishing Company, New York, 75 p. (NNA.940617.0032)

Barneyback, R.S., Jr., and Diamond, S., 1981, Expression and analysis of pore fluids from hardened cement pastes and mortars: Cement and Concrete Research, v. 11, p. 279285. (NNA.940617.0033)

Byers, F.M. Jr., Carr, W.J., Orkild, P.P., Quinlivan, W.D., and Sargent, K.A., 1976, Volcanic suites and related cauldrons of Timber Mountain-Oasis Valley Caldera Complex, southern Nevada: U.S. Geological Survey Professional Paper 919, 70 p. (NNA.870406.0239)

Connolly, J.R., Keil, K., Mansker, W.L., Allen, C.C., Husler, J., Lowy, R., Fortney, D.R., and Lappin, A.R., 1984, Petrology and geochemistry of samples from bedcontact zones in Tunnel bed 5, U12g-Tunnel, Nevada Test Site: Sandia National Laboratories Report SAND84-1060, 44 p. (NNA.900810.0672)

Connolly, J.R., Mansker, W.L., Hicks, R., Allen, C.C., Husler, J., Keil, K., and Lappin, A.R., 1983, Petrology and geochemistry of the Grouse Canyon Member of the Belted Range Tuff, Rock-mechanics drift, U12g Tunnel, Nevada Test Site: Sandia National Laboratories Report SAND81-1970, 72 p. (NNA.900702.0024)

Dake, L.P., 1978, Fundamentals of reservoir engineering: Elseveir Scientific Publishing Company, Amsterdam, Netherlands, 443 p. (NNA.940606.0062)

Devine, S.B., Ferrel, R.E., Jr., and Billings, G.K., 1973, The significance of ion exchange to interstitial solutions in clayey sediments: Chemical Geology, v. 12, p. 219-228. (NNA.940617.0034)

Draper, N.R., and Smith, H., 1966, Applied regression analysis: John Wiley and Sons, New York, NY, p. 1-35. (NNA.940617.0035) 
Dropek, R.K., and Levinson, A., 1975, Progress report IIWater extraction from Nevada Test Site tuffs:

Terra Tek Report TR 75-52, 357 p.

(NNA.940617.0036)

Edmunds, W.M., and Bath, A.H., 1976, Centrifuge extraction and chemical analysis of interstitial waters: Environmental Science and Technology, v. 10, p. 467472. (NNA.940617.0037)

Freeze, R.A., and Cherry, J.A., 1979, Groundwater: Prentice-Hall Inc., Englewood Cliffs, NJ, 604 p. (NNA.870406.0444)

Gibbons, A.B., Hinrichs, E.N., Hansen, W.R., and Lemke, R.W., 1963, Geology of the Rainier Mesa Quadrangle, Nye County, Nevada: U.S. Geological Survey Geologic Quadrangle Map GQ-215. (NNA.911114.0028)

Handin, J., and Hager, R.V., Jr., 1957, Experimental deformation of sedimentary rocks under confining pressure: tests at room temperature on dry samples: American Association of Petroleum Geologists Bulletin, v. 41, p. 1-50. (NNA.940520.0068)

Hay, R.L., 1966, Zeolites and zeolitic reactions in sedimentary rocks: Geological Society of America Special Paper 85, 130 p. (NNA.940520.0069)

Jones, M.P., 1987, Applied mineralogy: A quantitative approach: Graham and Trotman, London, UK, 259 p. (NNA.940602.0455)

Knowlton, G.D., and McKague, H.L., 1976, A study of the water content in zeolitic tuffs from the Nevada Test Site: Lawrence Livermore Laboratory Preprint UCRL-78013, 15 p. (NNA.940617.0038)

Lieu, K., Williford, C.W., Jr., and Reynolds, W.R., 1988, Comparison of wet chemistry CEC determinations, in Occurrence, properties, and utilization of natural zeolites, Kallo, D., and Sherry, H.S., eds., 1988, Akademiai Kaido, Budapest, Hungary, p. 541-550. (NNA.940525.0012)

Lipman, P.W., Christiansen, R.L., and O'Connor, J.T., 1966, A compositionally zoned ash-flow sheet in southern Nevada: U.S. Geological Survey Professional Paper 524F, 47 p. (NNA.870519.0035)

Manger, G.E., 1965, The best value of porosity of lapilli tuff from the Nevada Test Site: U.S. Geological Survey Professional Paper 525-B, p. B146-B150. (NNA.940602.0263)

Manheim, F.T., 1974, Comparative studies on extraction of sediment interstitial waters: Discussion and comment on the current state of interstitial water studies: Clay and Clay Minerals, v. 22, p. 337-343. (NNA.940602.0263)

Monicard, R.P., 1980, Properties of reservoir rocks: Core analysis: Gulf Publishing Company, Book Division, Houston, Texas, 168 p. (NNA.940602.0456)

Montazer, P., and Wilson, W.E., 1984, Conceptual hydrologic model of flow in the unsaturated zone, Yucca
Mountain, Nevada: U.S. Geological Survey WaterResources Investigations Report 84-4345, 55 p. (NNA.870519.0109)

Purcell, W.R., 1949, Capillary pressures-their measurement using mercury and calculation of permeability therefrom: Petroleum Transactions, AIME, February issue, p. 39-48. (NNA.890522.0236)

Rieke, H.H., III, Chilingarian, G.V., and Robertson, J.O., Jr., 1964, High-pressure (up to $500,000 \mathrm{psi}$ ) compaction studies on various clays: International Geological Congress, 22nd, part 15, p. 22-38. (NNA.940621.0003)

Rieke, H.H., III, and Chilingarian, G.V., 1974, Compaction of argillaceous sediments: Developments in Sedimentology, v. 16, Elsevier, Amsterdam, 424 p. (NNA.940606.0013)

Sayre, T.M., 1985, Pore-water extraction by triaxial compression from unsaturated tuff, Yucca Mountain, Nevada: Master of Engineering Report ER-3121, Colorado School of Mines, Golden, Colorado, $138 \mathrm{p}$. (NNA.940606.0063)

Schlumberger, Inc., 1987, Log interpretation principles/ applications: Schlumberger Educational Services, Houston, TX, 198 p. (NNA.940606.0064)

Scholl, D.W., 1963, Techniques for removing interstitial water from coarse-grained sediments for chemical analyses: Sedimentology, v. 2, p. 156-163. (NNA.940602.0267)

Sherry, H.S., 1971, Cation exchange on zeolites: in Molecular Sieve Zeolites-I, Flanigen, E., and Sand, L.B., co-chairmen, American Chemical Society, Washington, D.C., p. 350-379. (NNA.940617.0039)

Singer, A., and Muller, G., 1983, Diagenesis in argillaceous sediments, in: Diagenesis in sediments and sedimentary rocks, 2, Larsen, G., and Chilingar, G.V., eds., Elsevier Scientific Publishing Company, Amsterdam, Netherlands, p. 115-212. (NNA.940606.0014)

Slaughter, M., 1990, Quantitative determination of clays and other minerals in rock, in Clay Mineral Society workshop lectures, vol. 1, Quantitative mineral analysis of clays, Pevear, D.R., and Mumpton, F.A., eds., Clay Mineral Society, Evergreen, Colorado, p. 120-151. (NNA.921124.0009)

Stumm, W., and Morgan, J.J., 1981, Aquatic chemistry-an introduction emphasizing chemical equilibria in natural waters: John Wiley \& Sons, New York, NY, 2nd ed., 780 p. (NNA.940606.0015)

White, A.F., Claassen, H.C., and Benson, L.V., 1980, The effect of dissolution of volcanic glass on the water chemistry in a tuffaceous aquifer, Rainier Mesa, Nevada: U.S. Geological Survey Water-Supply Paper 1535-Q, 34 p. (HQS.880517.1868)

Yang, I.C., Davis, G.S., and Sayre, T.M., 1990, Comparison of pore-water extraction by triaxial compression and high-speed centrifugation methods: in Proceedings of 
the 1990 Spring Meeting, March 12-16, 1990 , American Institute of Hydrology, St. Paul, MN. (HQX.910205.0055)

Yang, I.C., Turner, A.K., Sayre, T.M., and Montazer, P., 1988, Triaxial-compression extraction of pore water from unsaturated tuff, Yucca Mountain, Nevada: U.S. Geological Survey Water-Resources Investigations Report 88-4189, 68 p. (NNA.890309.0161)
Zimmerman, R.M., and Finley, R.E., 1987, Summary of geomechanical measurements taken in and around G-Tunnel Underground Facility, NTS: Sandia National Laboratories Report SAND86-1015, 152 p. (NNA.870526.0015) 
SUPPLEMENTAL INFORMATION 


\section{SAMPLE NAMING CONVENTION}

66 Pore-Water Extraction from Unsaturated Tuff by Triaxial and One-Dimensional Compression Methods, Nevada Test Site, Nevada 


\section{SAMPLE NAMING CONVENTION}

The sample naming convention used in this report was designed only to reduce the length of sample names while maintaining an appropriate and unique name for each test specimen. The naming system is not designed to include the complete borehole name in each sample name nor is it a standard system used in naming samples from the NTS.

\section{Yucca Mountain Samples}

All Yucca Mountain samples are taken from the following vertical boreholes: UE-25 UZ \#4, UE-25 UZ \#5, USW UZ-13, and USW UZ-N46. Core samples from Yucca Mountain boreholes are designated in this report by the abbreviated borehole name and the depth from surface, rounded to the nearest foot, from which the core was taken in that borehole. For example:

\section{Example Yucca Mountain sample name:} UZ5-235

Sample description: Borehole UE-25 UZ \#5, depth 235 feet

Using this naming method, and depending upon the location of a particular test specimen within a core segment, two test cores may have the same sample name. To create a unique name in these instances, a second core that would have a repeat name was assigned the next nearest footage location. This occasionally occurred when two adjacent test specimens were cut from the same core segment as is illustrated in the following example:

Test specimen 1:

Borehole: UE-25 UZ \#5

Depth to middle of specimen: 333.7 feet

Sample name: UZ5-334

Test specimen 2:

Borehole: UE-25 UZ \#5

Depth to middle of specimen: $334.3 \mathrm{feet}$

Sample name: UZ5-334

Modified sample name: UZ5-335

For Yucca Mountain borehole core samples, test specimens that have consecutive names were, in fact, adjacent pieces of a single core segment. (The only exception to this statement is sample UZ5-333. Sample UZ5-333 was not directly adjacent to sample UZ5-334 in the same core segment.)

\section{G-Tunnel Samples}

Samples that were collected in G-Tunnel originated in one of two forms-as cores taken from horizontal boreholes or as blocks of blast rubble created by the excavation of a drift.

\section{Cores}

Cores collected from horizontal boreholes are designated by the prefix "GT". The second set of letters represents the drift in G-Tunnel where the borehole is located. The third letter/number combination stands for the name of the borehole. The final number is the depth from the drift face in feet from which the core was taken. The following list shows all the drifts and boreholes from which core samples were obtained and their corresponding letter codes.

$\begin{array}{ll}\begin{array}{l}\text { Drifts used for core } \\ \text { samples: }\end{array} & \text { Borehole: } \\ \begin{array}{l}\text { Laser drift (LD) } \\ \text { Extension drift (EX) }\end{array} & \text { Air Core \#2 (AC2) } \\ & \text { Drill Hole \#3 (DH3) } \\ \text { Demonstration drift (DD) } & \text { "A" Hole (A) }\end{array}$

Example G-Tunnel borehole core sample name:

Sample name: GT-LD-AC2-25

Sample description: G-Tunnel core, Laser drift, borehole Air Core \#2, depth 25 feet

Duplicate sample names were avoided using the same method as described for Yucca Mountain borehole cores. For all G-Tunnel borehole cores, consecutive sample names indicate that the specimens originally were adjacent pieces in the same core segment.

\section{Blast-Rubble Blocks}

Cores which were cut in the U.S. Bureau of Reclamation Earth Mechanics Laboratory (at the Denver Federal Center) from blocks of G-Tunnel blast rubble are designated with the efix "GTO" or "GTG". (The trailing "O" or "G" stanc.s for an individual prototype test for which the rubble block was excavated.) The second set of letters represents the drift where the rubble was excavated. The third set of letters describes the drilling method used to drill the holes for the blasting explosives (DB for dry-drilled, WB for wet-drilled). The fourth number or number/letter combination identifies an individual block among a group taken from the same blast round. (A number/letter pair is used when a single block is cut or broken into more than one piece; 
the pieces are labeled "A", "B", etc. depending on the number of pieces.) The fifth number indicates a single core among several cores taken from the same block. The sixth, and final, number identifies a particular specimen taken from a single core. The drifts from which rubble blocks were collected are listed below with the corresponding abbreviations.

Drifts used for rubble samples:

Junior J drift (JJ)

Laser drift (LD)

Example G-Tunnel blast rubble core sample name:

Sample name: GTO-JJ-DB-1A-2-1

Sample description: G-Tunnel rubble block core, Junior J drift, dry-drilled blast holes, block 1, piece A, core 2 (from block 1A), test specimen 1 (from core 2)

As is evident from the example, one rubble block may be subdivided into several subsamples, one block may have several cores taken from it, and one core may provide several test specimens. Although the names of test specimens are long, they uniquely identify each sample without the need for a cross-reference.

\section{Extracted Water Samples}

The identifier for each water sample is added to the end of the name of the test core. Water samples extracted from each test specimen are numbered consecutively as they are collected during pore-water extraction.

Example water sample name:

Sample name: GTO-JJ-DB-1A-2-1-7

Sample description: G-Tunnel rubble block core, Junior J drift, dry-drilled blast holes, block 1, piece A, core 2 (from block 1A), test specimen 1 (from core 2), water sample 7. 


\section{MERCURY INJECTION DATA FOR TUFFS}




\section{Table 18. Mercury injection data for tuffs}

(Data reported in units as received from Surtek, Inc., laboratory; psia, pounds per square inch, absolute. All aftercompression samples listed in this table were compressed to a maximum axial stress of $552 \mathrm{MPa}$ using one-dimensional compression]

\begin{tabular}{|c|c|c|c|}
\hline Sample name' & $\begin{array}{l}\text { Mercury saturation } \\
\text { (percent) }\end{array}$ & $\begin{array}{c}\text { Caplliary pressure } \\
\text { (psia) }\end{array}$ & $\begin{array}{l}\text { Pore-throat radlus } \\
\text { (micrometer) }\end{array}$ \\
\hline \multicolumn{4}{|c|}{ Drainage } \\
\hline \multirow[t]{33}{*}{ UZ5-335-BC } & 0.0 & 4.1 & 26.0 \\
\hline & 1.1 & 4.6 & 23.2 \\
\hline & 3.3 & 7.1 & 15.2 \\
\hline & 5.5 & 9.5 & 11.3 \\
\hline & 10.4 & 12.0 & 8.95 \\
\hline & 19.7 & 16.0 & 6.71 \\
\hline & 21.9 & 20.0 & 5.37 \\
\hline & 24.7 & 26.0 & 4.13 \\
\hline & 31.2 & 32.0 & 3.36 \\
\hline & 32.3 & 42.0 & 2.56 \\
\hline & 37.3 & 62.0 & 1.73 \\
\hline & 40.0 & 82.0 & 1.31 \\
\hline & 40.5 & 112.0 & 0.96 \\
\hline & 43.3 & 162.0 & 0.66 \\
\hline & 43.8 & 212.0 & 0.51 \\
\hline & 44.9 & 312.0 & 0.34 \\
\hline & 46.0 & 412.0 & 0.26 \\
\hline & 46.0 & 612.0 & 0.18 \\
\hline & 47.1 & 812.0 & 0.13 \\
\hline & 47.7 & 1012.0 & 0.11 \\
\hline & 48.2 & 1212.0 & 0.09 \\
\hline & 48.8 & 1612.0 & 0.07 \\
\hline & 49.3 & 2012.0 & 0.05 \\
\hline & \multicolumn{2}{|c|}{ Imbibition } & \\
\hline & 49.9 & 1212.0 & 0.09 \\
\hline & 49.3 & 812.0 & 0.13 \\
\hline & 47.7 & 412.0 & 0.26 \\
\hline & 47.1 & 212.0 & 0.51 \\
\hline & 46.0 & 112.0 & 0.96 \\
\hline & 45.5 & 62.0 & 1.73 \\
\hline & 43.8 & 32.0 & 3.36 \\
\hline & 42.2 & 12.0 & 8.95 \\
\hline & 31.2 & 4.1 & 26.0 \\
\hline
\end{tabular}


Table 18. Mercury injection data for tufts ..Continued

\begin{tabular}{|c|c|c|c|}
\hline Sample name' & $\begin{array}{l}\text { Mercury saturation } \\
\text { (percent) }\end{array}$ & $\begin{array}{c}\text { Capillary pressure } \\
\text { (pola) }\end{array}$ & $\begin{array}{l}\text { Pore-throet radlus } \\
\text { (micrometer) }\end{array}$ \\
\hline \multicolumn{4}{|c|}{ Drainage } \\
\hline \multirow[t]{33}{*}{ UZ5-335-AC } & 0.0 & 4.1 & 26.0 \\
\hline & 2.8 & 4.6 & 23.2 \\
\hline & 5.1 & 7.1 & 15.2 \\
\hline & 6.2 & 9.5 & 11.3 \\
\hline & 7.6 & 12.0 & 8.95 \\
\hline & 11.2 & 16.0 & 6.71 \\
\hline & 13.5 & 20.0 & 5.37 \\
\hline & 14.3 & 26.0 & 4.13 \\
\hline & 14.6 & 32.0 & 3.36 \\
\hline & 14.6 & 42.0 & 2.56 \\
\hline & 16.9 & 62.0 & 1.73 \\
\hline & 16.9 & 82.0 & 1.31 \\
\hline & 17.4 & 112.0 & 0.96 \\
\hline & 19.1 & 162.0 & 0.66 \\
\hline & 20.2 & 212.0 & 0.51 \\
\hline & 23.0 & 312.0 & 0.34 \\
\hline & 23.6 & 412.0 & 0.26 \\
\hline & 27.5 & 612.0 & 0.18 \\
\hline & 29.8 & 812.0 & 0,13 \\
\hline & 31.5 & 1012.0 & 0.11 \\
\hline & 34.3 & 1212.0 & 0.09 \\
\hline & 39.3 & 1612.0 & 0.07 \\
\hline & 43.3 & 2012.0 & 0.05 \\
\hline & \multicolumn{2}{|c|}{ Imbibition } & \\
\hline & 38.2 & 1212.0 & 0.09 \\
\hline & 35.4 & 812.0 & 0.13 \\
\hline & 34.3 & 412.0 & 0.26 \\
\hline & 31.5 & 212.0 & 0.51 \\
\hline & 30.9 & 112.0 & 0.96 \\
\hline & 30.3 & 62.0 & 1.73 \\
\hline & 29.2 & 32.0 & 3.36 \\
\hline & 28.1 & 12.0 & 8.95 \\
\hline & 27.5 & 4.1 & 26.0 \\
\hline
\end{tabular}


Table 18. Mercury injection data for tuffs -..Continued

\begin{tabular}{|c|c|c|c|}
\hline Sample name' & $\begin{array}{l}\text { Mercury saturation } \\
\text { (percent) }\end{array}$ & $\begin{array}{c}\text { Capillary pressure } \\
\text { (pala) }\end{array}$ & $\begin{array}{l}\text { Pore-throat radlus } \\
\text { (micrometer) }\end{array}$ \\
\hline \multicolumn{4}{|c|}{ Drainage } \\
\hline \multirow{32}{*}{ GTO-J]-DB-IA-2-1-BC } & 0.0 & 3.3 & 32.8 \\
\hline & 0.0 & 4.7 & 22.6 \\
\hline & 1.0 & 7.2 & 14.9 \\
\hline & 2.0 & 9.7 & 11.1 \\
\hline & 5.1 & 12.1 & 8.86 \\
\hline & 6.1 & 16.1 & 6.66 \\
\hline & 27.9 & 26.1 & 4.11 \\
\hline & 34.0 & 32.1 & 3.34 \\
\hline & 43.1 & 42.1 & 2.55 \\
\hline & 49.2 & 62.1 & 1.73 \\
\hline & 52.8 & 82.1 & 1.31 \\
\hline & 56.3 & 112.1 & 0.96 \\
\hline & 57.9 & 162.1 & 0.66 \\
\hline & 60.9 & 212.1 & 0.51 \\
\hline & 62.9 & 312.1 & 0.34 \\
\hline & 63.5 & 412.1 & 0.26 \\
\hline & 66.0 & 612.1 & 0.18 \\
\hline & 67.5 & 812.1 & 0.13 \\
\hline & 68.5 & 1012.1 & 0.11 \\
\hline & 69.0 & 1212.1 & 0.09 \\
\hline & 69.5 & 1612.1 & 0.07 \\
\hline & 70.1 & 2012.1 & 0.05 \\
\hline & \multicolumn{2}{|c|}{ Imbibition } & \\
\hline & 69.5 & 1212.1 & 0.09 \\
\hline & 69.0 & 812.1 & 0.13 \\
\hline & 68.5 & 412.1 & 0.26 \\
\hline & 68.0 & 212.1 & 0.51 \\
\hline & 66.0 & 112.1 & 0.96 \\
\hline & 64.5 & 62.1 & 1.73 \\
\hline & 62.9 & 32.1 & 3.34 \\
\hline & 61.4 & 12.1 & 8.86 \\
\hline & 59.9 & 3.3 & 32.8 \\
\hline
\end{tabular}


Table 18. Mercury injection data for tufls -.-Continued

\begin{tabular}{|c|c|c|c|}
\hline Sample name' & $\begin{array}{l}\text { Morcury saturation } \\
\text { (percent) }\end{array}$ & $\begin{array}{c}\text { Capillary prosesuro } \\
\text { (psia) }\end{array}$ & $\begin{array}{l}\text { Pore-throat radius } \\
\text { (micromotor) }\end{array}$ \\
\hline \multicolumn{4}{|c|}{ Drainage } \\
\hline \multirow[t]{33}{*}{ GTO-JJ-DB-1A-2-1-AC } & 0.0 & 4.2 & 25.5 \\
\hline & 0.5 & 4.7 & 22.8 \\
\hline & 0.5 & 7.2 & 15.0 \\
\hline & 1.1 & 9.6 & 11.2 \\
\hline & 1.4 & 12.1 & 8.89 \\
\hline & 2.2 & 16.1 & 6.68 \\
\hline & 3.2 & 20.1 & 5.35 \\
\hline & 3.5 & 26.1 & 4.12 \\
\hline & 3.8 & 32.1 & 3.35 \\
\hline & 4.3 & 42.1 & 2.55 \\
\hline & 5.4 & 62.1 & 1.73 \\
\hline & 5.9 & 82.1 & 1.31 \\
\hline & 6.5 & 112.1 & 0.96 \\
\hline & 8.6 & 162.1 & 0.66 \\
\hline & 10.3 & 212.1 & 0.51 \\
\hline & 18.9 & 312.1 & 0.34 \\
\hline & 24.3 & 412.1 & 0.26 \\
\hline & 32.4 & 612.1 & 0.18 \\
\hline & 36.2 & 812.1 & 0.13 \\
\hline & 41.6 & 1012.1 & 0.11 \\
\hline & 45.9 & 1212.1 & 0.09 \\
\hline & 52.4 & 1612.1 & 0.07 \\
\hline & 56.8 & 2012.1 & 0.05 \\
\hline & \multicolumn{2}{|c|}{ Imbibition } & \\
\hline & 54.6 & 1212.1 & 0.09 \\
\hline & $\$ 1.9$ & 812.1 & 0.13 \\
\hline & 47.6 & 412.1 & 0.26 \\
\hline & 43.8 & 212.1 & 0.51 \\
\hline & 39.5 & 112.1 & 0.96 \\
\hline & 37.8 & 62.1 & 1.73 \\
\hline & 36.8 & 32.1 & 3.35 \\
\hline & 33.5 & 12.1 & 8.89 \\
\hline & 33.0 & 4.2 & 25.5 \\
\hline
\end{tabular}


Table 18. Mercury injection data for tults --Continued

\begin{tabular}{|c|c|c|c|}
\hline Sample name' & $\begin{array}{l}\text { Mercury saturation } \\
\text { (percent) }\end{array}$ & $\begin{array}{l}\text { Capilitary proseure } \\
\text { (pala) }\end{array}$ & $\begin{array}{l}\text { Pora-throat radlus } \\
\text { (mlerometer) }\end{array}$ \\
\hline \multicolumn{4}{|c|}{ Drainage } \\
\hline \multirow[t]{33}{*}{ GT-LD-AC2-55-BC } & 0.0 & 4.1 & 26.0 \\
\hline & 1.5 & 4.6 & 23.2 \\
\hline & 1.9 & 7.1 & 15.2 \\
\hline & 2.9 & 9.5 & 11.3 \\
\hline & 4.1 & 12.0 & 8.95 \\
\hline & 4.8 & 16.0 & 6.71 \\
\hline & 4.8 & 20.0 & 5.37 \\
\hline & 5.6 & 26.0 & 4.13 \\
\hline & 5.8 & 32.0 & 3.36 \\
\hline & 6.8 & 42.0 & 2.56 \\
\hline & 8.2 & 62.0 & 1.73 \\
\hline & 9.2 & 82.0 & 1.31 \\
\hline & 10.2 & 112.0 & 0.96 \\
\hline & 15.0 & 162.0 & 0.66 \\
\hline & 14.5 & 212.0 & 0.51 \\
\hline & 16.0 & 312.0 & 0.34 \\
\hline & 17.4 & 412.0 & 0.26 \\
\hline & 21.8 & 612.0 & 0.18 \\
\hline & 29.1 & 812.0 & 0.13 \\
\hline & 35.4 & 1012.0 & 0.11 \\
\hline & 42.1 & 1212.0 & 0.09 \\
\hline & 49.4 & 1612.0 & 0.07 \\
\hline & 54.2 & 2012.0 & 0.05 \\
\hline & \multicolumn{2}{|c|}{ Imbibition } & \\
\hline & 55.2 & 1212.0 & 0.09 \\
\hline & 54.2 & 812.0 & 0.13 \\
\hline & 52.3 & 412.0 & 0.26 \\
\hline & 41.6 & 212.0 & 0.51 \\
\hline & 40.2 & 112.0 & 0.96 \\
\hline & 37.8 & 62.0 & 1.73 \\
\hline & 36.3 & 32.0 & 3.36 \\
\hline & 35.8 & 12.0 & 8.95 \\
\hline & 35.4 & 4.1 & 26.0 \\
\hline
\end{tabular}


Table 18. Mercury injection data for tuffs --Continued

\begin{tabular}{|c|c|c|c|}
\hline Sample name' & $\begin{array}{l}\text { Mercury saturation } \\
\text { (percent) }\end{array}$ & $\begin{array}{c}\text { Capillary pressure } \\
\text { (psia) }\end{array}$ & $\begin{array}{l}\text { Pore-throat radius } \\
\text { (micrometer) }\end{array}$ \\
\hline \multicolumn{4}{|c|}{ Drainage } \\
\hline \multirow[t]{33}{*}{ GT-LD-AC2-55-AC } & 0.0 & 4.2 & 25.5 \\
\hline & 0.6 & 4.7 & 22.8 \\
\hline & 1.7 & 7.2 & 15.0 \\
\hline & 2.8 & 9.6 & 11.2 \\
\hline & 3.1 & 12.1 & 8.89 \\
\hline & 4.5 & 16.1 & 6.68 \\
\hline & 4.5 & 20.1 & 5.35 \\
\hline & 6.0 & 26.1 & 4.12 \\
\hline & 6.3 & 32.1 & 3.35 \\
\hline & 6.8 & 42.1 & 2.55 \\
\hline & 8.5 & 62.1 & 1.73 \\
\hline & 10.2 & 82.1 & 1.31 \\
\hline & 11.4 & 112.1 & 0.96 \\
\hline & 13.6 & 162.1 & 0.66 \\
\hline & 14.8 & 212.1 & 0.51 \\
\hline & 17.6 & 312.1 & 0.34 \\
\hline & 19.3 & 412.1 & 0.26 \\
\hline & 27.8 & 612.1 & 0.18 \\
\hline & 35.8 & 812.1 & 0.13 \\
\hline & 40.9 & 1012.1 & 0.11 \\
\hline & 45.5 & 1212.1 & 0.09 \\
\hline & 51.1 & 1612.1 & 0.07 \\
\hline & 56.2 & 2012.1 & 0.05 \\
\hline & \multicolumn{2}{|c|}{ Imbibition } & \\
\hline & 54.0 & 1212.1 & 0.09 \\
\hline & 52.3 & 812.1 & 0.13 \\
\hline & 50.6 & 412.1 & 0.26 \\
\hline & 47.2 & 212.1 & 0.51 \\
\hline & 44.3 & 112.1 & 0.96 \\
\hline & 43.8 & 62.1 & 1.73 \\
\hline & 43.2 & 32.1 & 3.35 \\
\hline & 41.5 & 12.1 & 8.89 \\
\hline & 40.9 & 4.2 & 25.5 \\
\hline
\end{tabular}


Table 18. Mercury injection data for tuffs --Continued

\begin{tabular}{|c|c|c|c|}
\hline Sample name' & $\begin{array}{l}\text { Mercury saturation } \\
\text { (percent) }\end{array}$ & $\begin{array}{c}\text { Capillary pressure } \\
\text { (psia) }\end{array}$ & $\begin{array}{l}\text { Pore-throat radius } \\
\text { (micrometer) }\end{array}$ \\
\hline \multicolumn{4}{|c|}{ Drainage } \\
\hline \multirow[t]{33}{*}{ GT-LD-AC2-62-BC } & 0.0 & 3.2 & 33.2 \\
\hline & 0.6 & 4.7 & 22.8 \\
\hline & 2.3 & 7.2 & 15.0 \\
\hline & 2.3 & 9.6 & 11.2 \\
\hline & 2.9 & 12.1 & 8.89 \\
\hline & 2.9 & 16.1 & 6.68 \\
\hline & 4.0 & 20.1 & 5.35 \\
\hline & 4.6 & 26.1 & 4.12 \\
\hline & 5.2 & 32.1 & 3.35 \\
\hline & 6.9 & 42.1 & 2.55 \\
\hline & 8.0 & $62 . i$ & 1.73 \\
\hline & 10.9 & 82.1 & 1.31 \\
\hline & 14.9 & 112.1 & 0.96 \\
\hline & 19.5 & 162.1 & 0.66 \\
\hline & 25.3 & 212.1 & 0.51 \\
\hline & 31.0 & 312.1 & 0.34 \\
\hline & 36.2 & 412.1 & 0.26 \\
\hline & 45.4 & 612.1 & 0.18 \\
\hline & 50.6 & 812.1 & 0.13 \\
\hline & 54.6 & 1012.1 & 0.11 \\
\hline & 58.0 & 1212.1 & 0.09 \\
\hline & 62.6 & 1612.1 & 0.07 \\
\hline & 63.2 & 2012.1 & 0.05 \\
\hline & \multicolumn{2}{|c|}{ Imbibition } & \\
\hline & 63.2 & 1212.1 & 0.09 \\
\hline & 62.6 & 812.1 & 0.13 \\
\hline & 62.6 & 412.1 & 0.26 \\
\hline & 62.1 & 212.1 & 0.51 \\
\hline & 61.5 & 112.1 & 0.96 \\
\hline & 60.3 & 62.1 & 1.73 \\
\hline & 59.8 & 32.1 & 3.35 \\
\hline & 59.2 & 12.1 & 8.89 \\
\hline & 58.0 & 3.2 & 33.2 \\
\hline
\end{tabular}


Table 18. Mercury injection data for tuffs --Continued

\begin{tabular}{|c|c|c|c|}
\hline Sample name ${ }^{1}$ & $\begin{array}{l}\text { Mercury saturation } \\
\text { (percent) }\end{array}$ & $\begin{array}{l}\text { Capillary pressure } \\
\text { (psia) }\end{array}$ & $\begin{array}{l}\text { Pore-throat radlus } \\
\text { (micrometer) }\end{array}$ \\
\hline \multicolumn{4}{|c|}{ Drainage } \\
\hline \multirow[t]{33}{*}{ GT-LD-AC2-62-AC } & 0.0 & 4.2 & 25.5 \\
\hline & 0.7 & 4.7 & 22.8 \\
\hline & 2.2 & 7.2 & 15.0 \\
\hline & 2.9 & 9.6 & 11.2 \\
\hline & 3.8 & 12.1 & 8.89 \\
\hline & 6.5 & 16.1 & 6.68 \\
\hline & 7.6 & 20.1 & 5.35 \\
\hline & 8.1 & 26.1 & 4.12 \\
\hline & 8.3 & 32.1 & 3.35 \\
\hline & 10.5 & 42.1 & 2.55 \\
\hline & 12.3 & 62.1 & 1.73 \\
\hline & 14.1 & 82.1 & 1.31 \\
\hline & 16.2 & 112.1 & 0.96 \\
\hline & 19.8 & 162.1 & 0.66 \\
\hline & 22.3 & 212.1 & 0.51 \\
\hline & 26.7 & 312.1 & 0.34 \\
\hline & 29.9 & 412.1 & 0.26 \\
\hline & 36.0 & 612.1 & 0.18 \\
\hline & 39.6 & 812.1 & 0.13 \\
\hline & 42.2 & 1012.1 & 0.11 \\
\hline & 44.3 & 1212.1 & 0.09 \\
\hline & 48.3 & 1612.1 & 0.07 \\
\hline & 51.2 & 2012.1 & 0.05 \\
\hline & \multicolumn{2}{|c|}{ Imbibition } & \\
\hline & 49.4 & 1212.1 & 0.09 \\
\hline & 48.3 & 812.1 & 0.13 \\
\hline & 47.2 & 412.1 & 0.26 \\
\hline & 45.8 & 212.1 & 0.51 \\
\hline & 44.0 & 112.1 & 0.96 \\
\hline & 42.9 & 62.1 & 1.73 \\
\hline & 41.1 & 32.1 & 3.35 \\
\hline & 39.3 & 12.1 & 8.89 \\
\hline & 36.8 & 4.2 & 25.5 \\
\hline
\end{tabular}

${ }^{1}$ Sample names ending with the suffix "-BC" indicate subsamples collected from end pieces created during preparation of the test cores before compression.

${ }^{2}$ Sample names ending with the suffix "-AC" indicate subsamples collected from test cores after compression. 


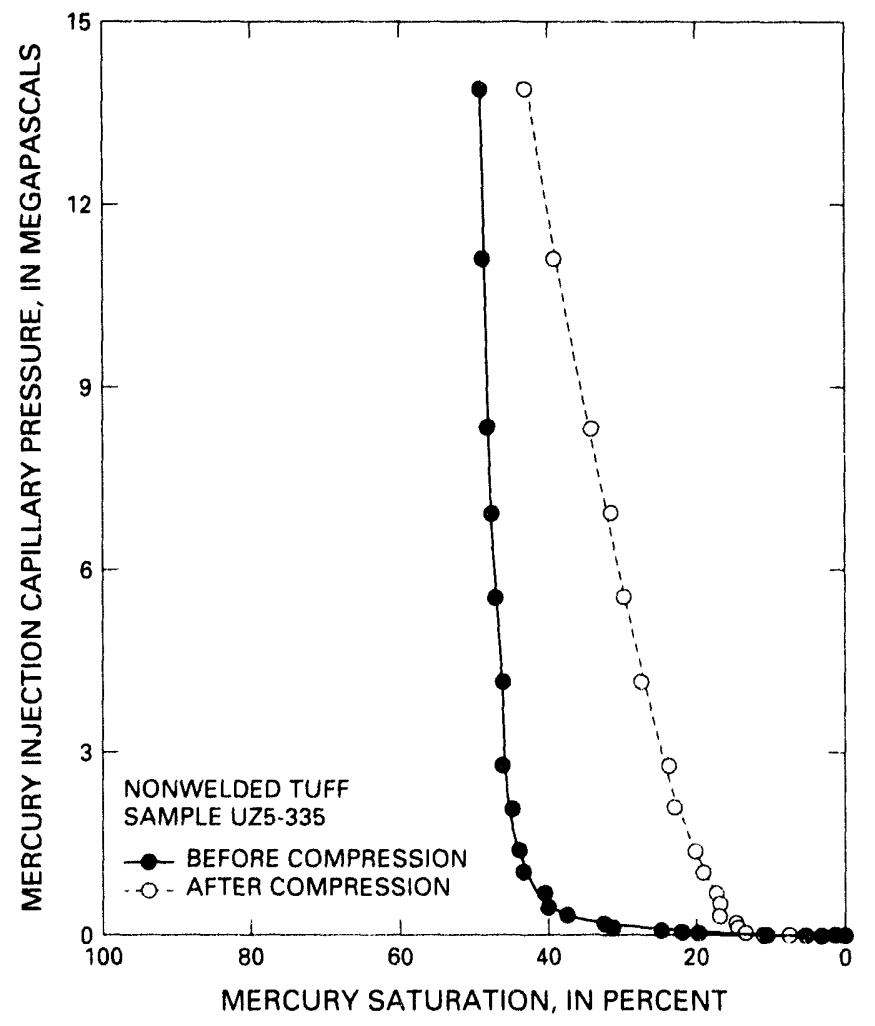

Figure 38. Capillary pressure curves for sample UZ5-335.

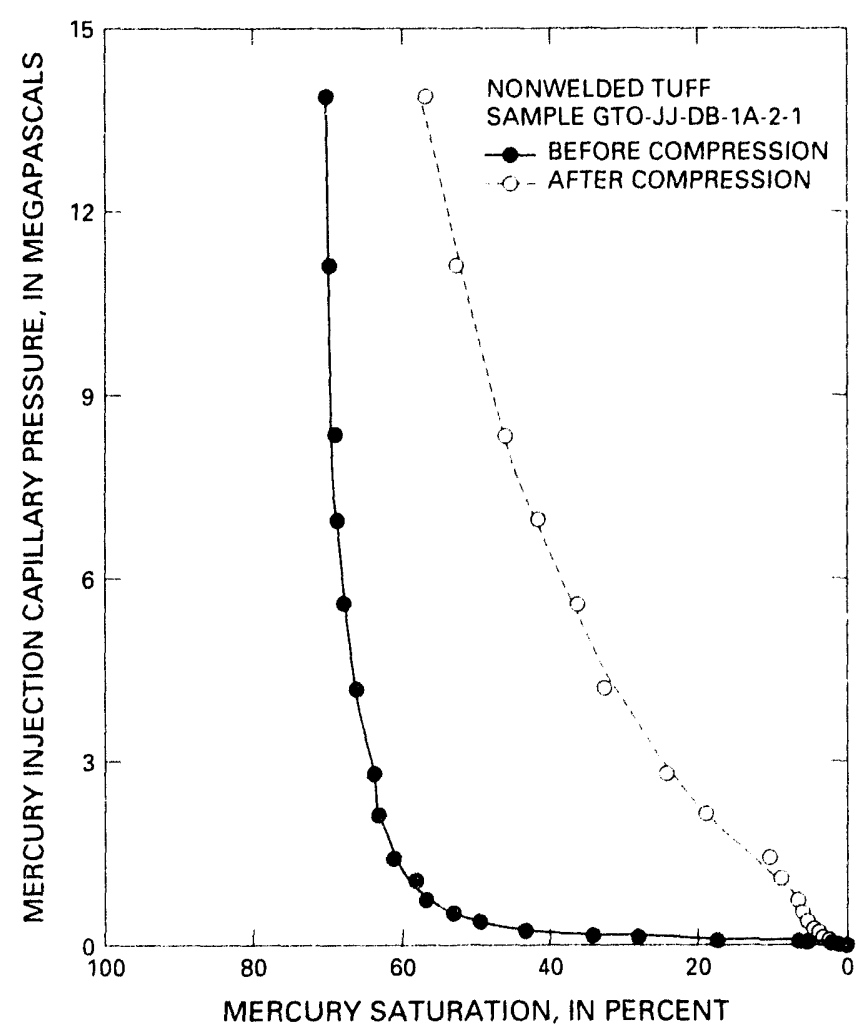

Figure 39. Capillary pressure curves for sample GTO-JJDB-1A-2-1.

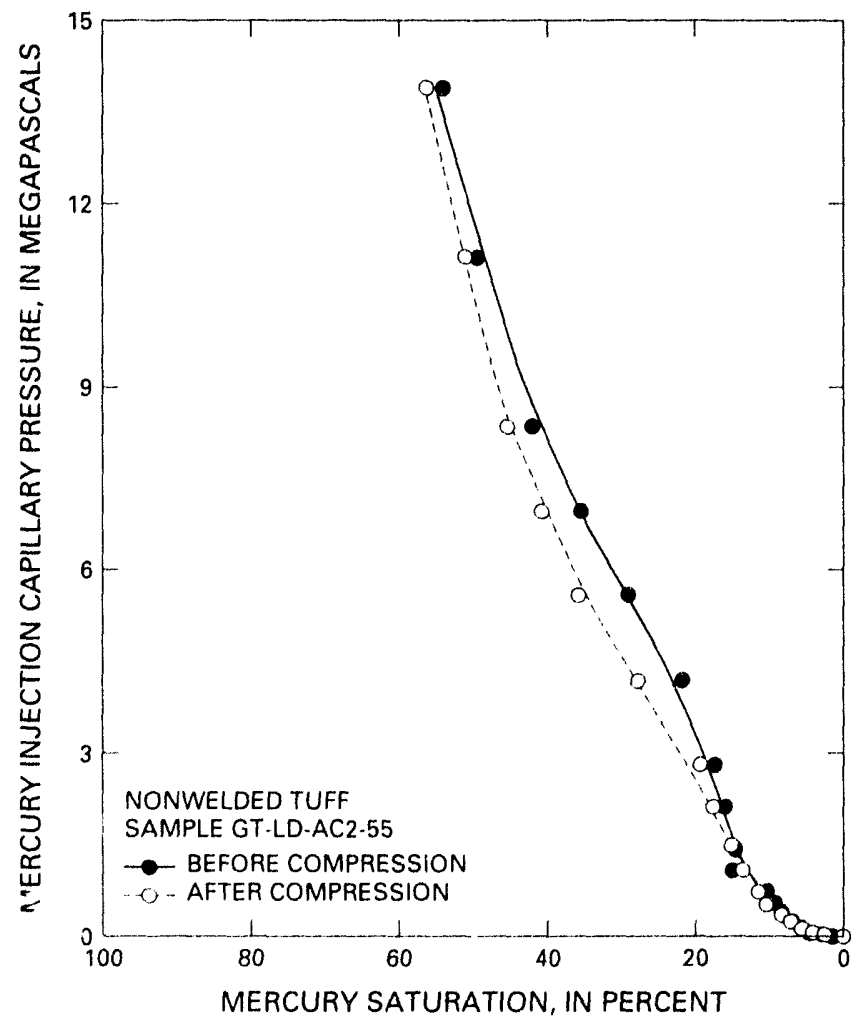

Figure 40. Capillary pressure curves for sample GT-LDAC2-55.

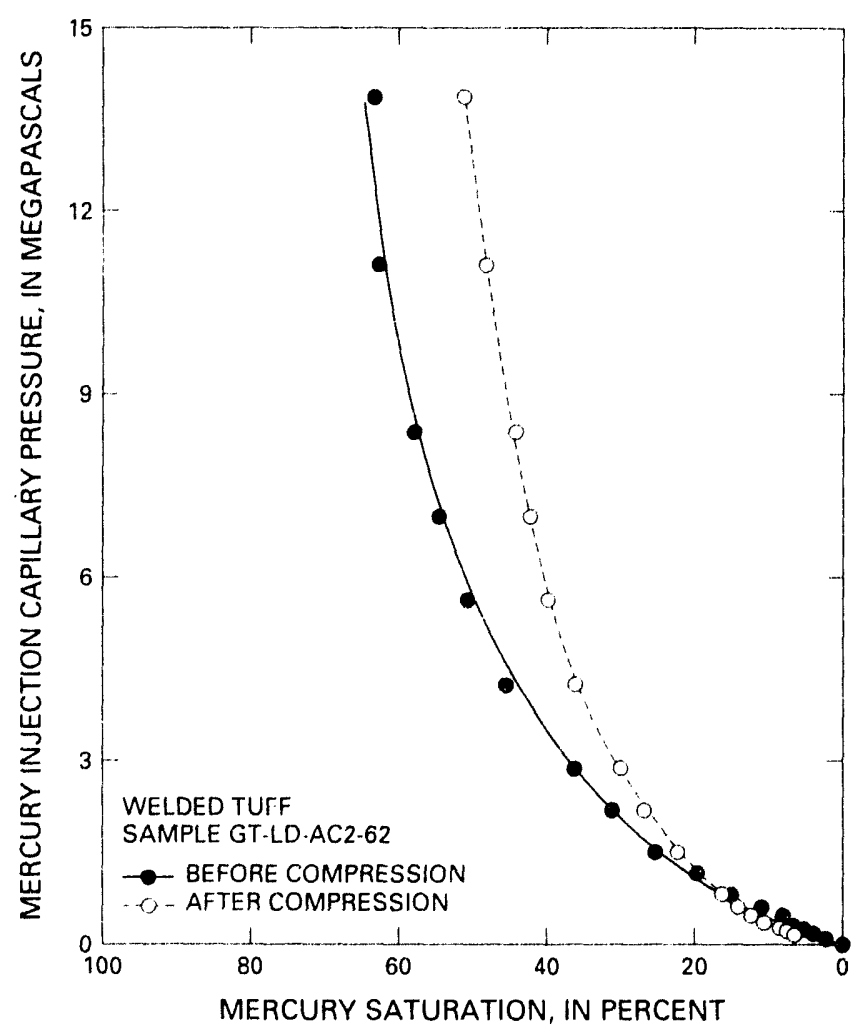

Figure 41. Capulary pressure curves for sample GT-LDAC2-62.

78 Pore-Water Extraction from Unsaturated Tuff by Triaxial and One-Dimensional Compression Methods, Nevada Test Site, Nevada 

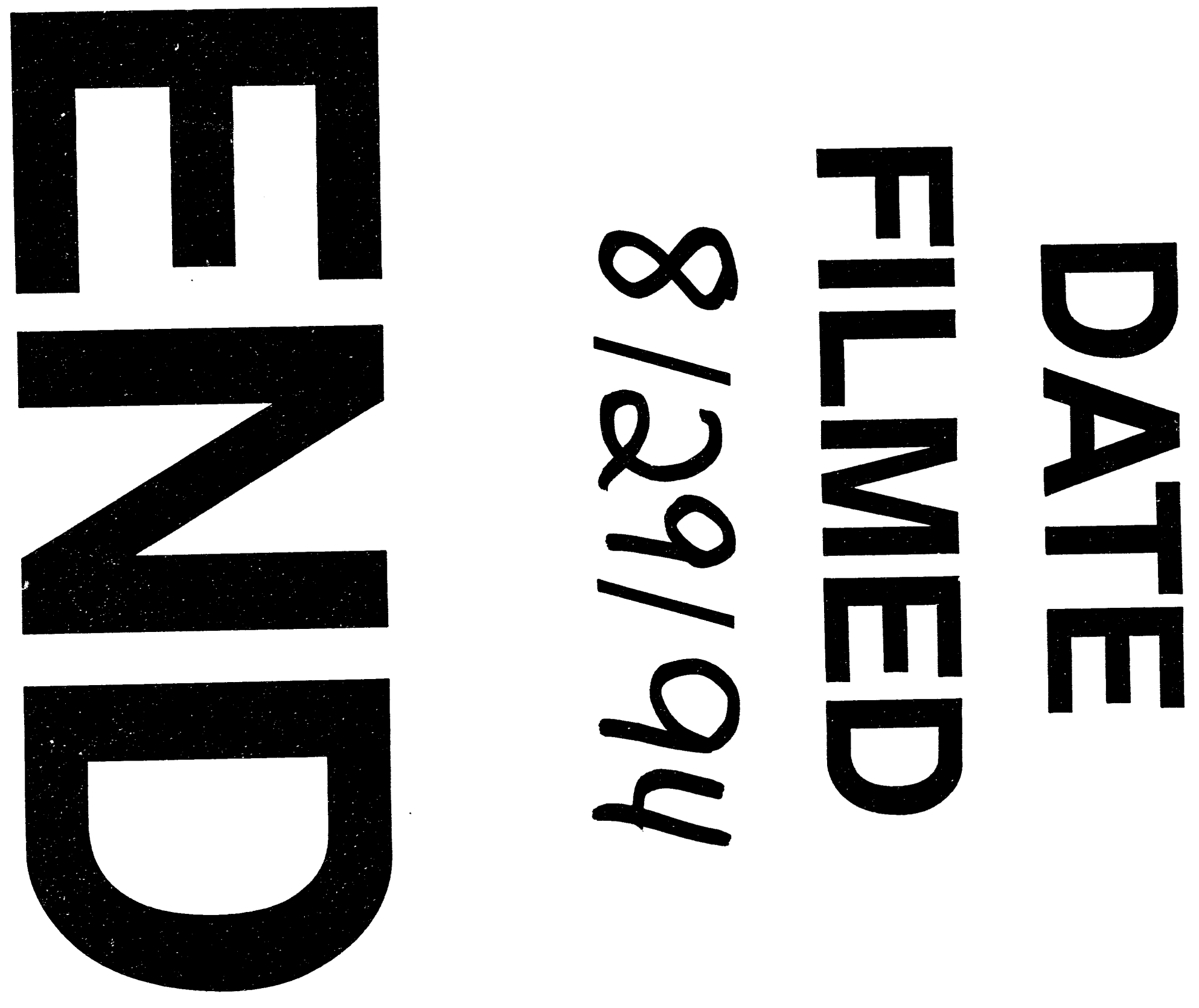
